\title{
Practhon:
}

atis $x$

\section{(3) $x(3)$}

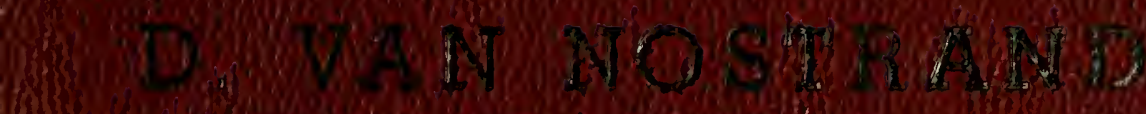

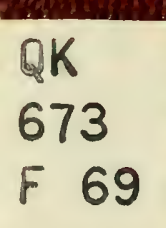
Q1)

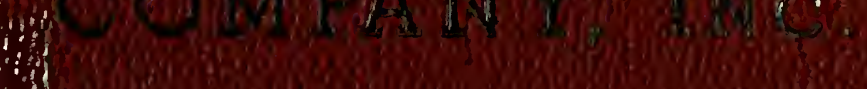


a.1

13.

13

G.as

$x^{2}+115$

60

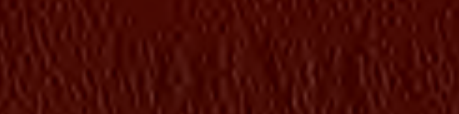

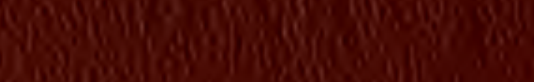

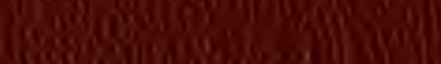

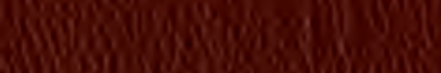

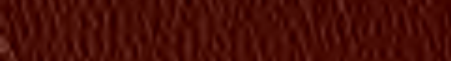

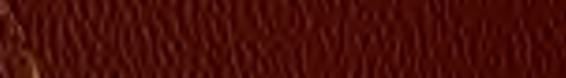

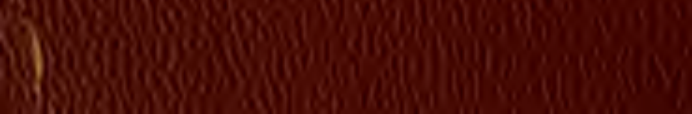



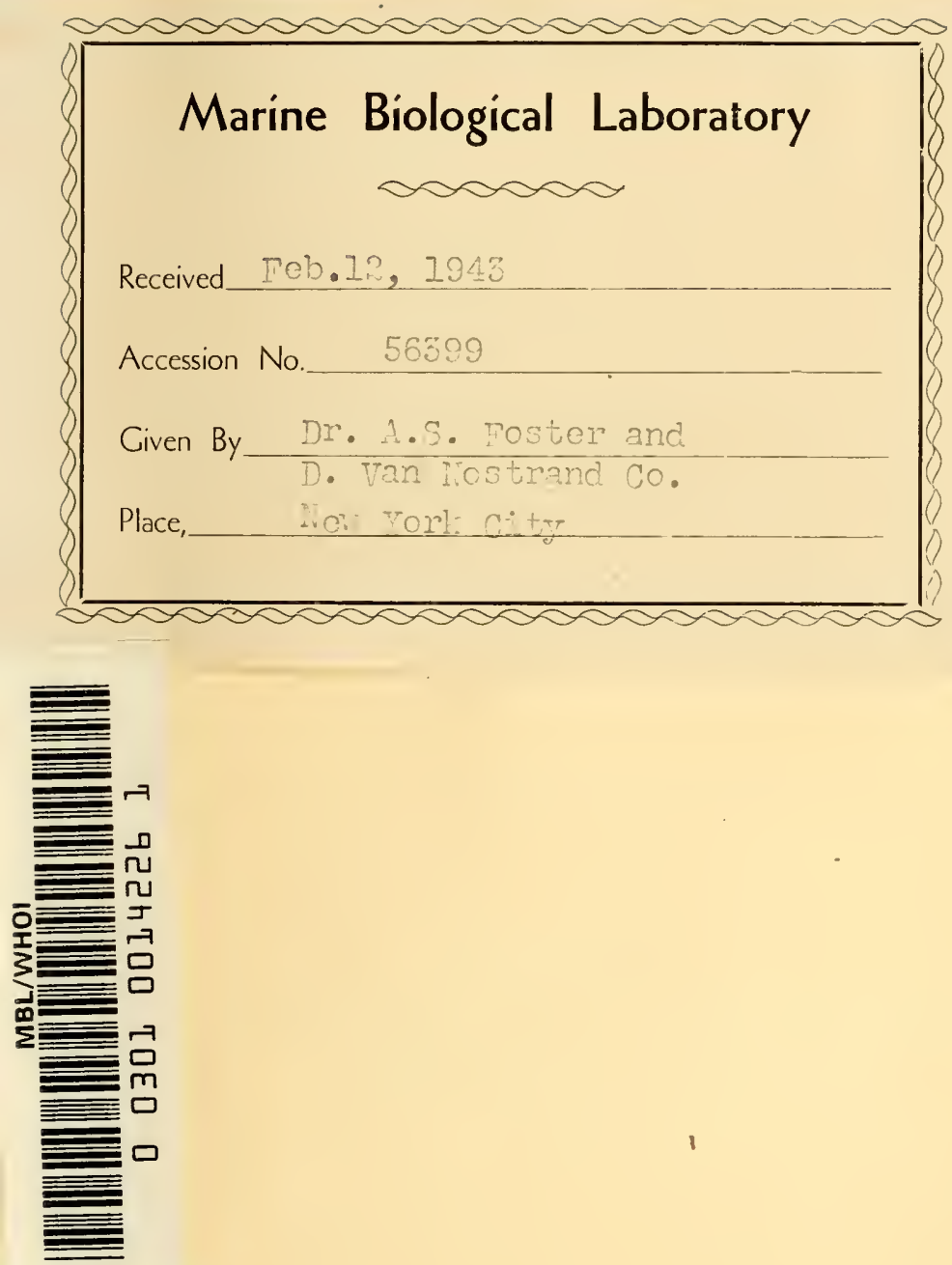



\title{
Practical
}

\section{Plant Anatomy}

$$
\text { By }
$$

\author{
ADRIANCE S. FOSTER \\ Associate Professor of Botany \\ University of California
}

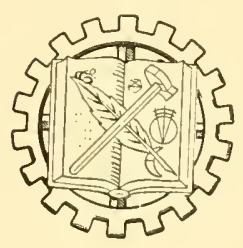

NEIV YORK

D. VAN NOSTRAND COMPANY, INC.

250 FOURTH AVENUE

$19+2$ 
Copyright, 1942

ly

D. TAN NOSTRANT COMPANY, INC.

111 Rights Reserved

This book or any part thereof may mot be reproduced in an!l form uifliout mitten permission finut the pubtishers.

PRTATED IN U.S.A.

Press of

Gaorse. S. Ferot son Co.

Philadelphia. Pa. 


$$
\sim \sim \diamond \sim
$$

To my wife

$-0 \sim$ 



\section{PREFACE}

Since a realistic foundation in plant anatomy depends upon thorough laboratory practice, there appears to be a definite need for a gruicle which will both direct as well as orient the student in his individual studies. The present book has been written from this standpoint and is therefore intended for use in the laboratory. Each exercise contains an introductory section in which an effort is made to summarize briefly but clearly the present status of knowledge of the subject for study. This "Introduction" is in no sense to be regarded as a substitute for' collateral reading in the standard texts in plant anatomy and in the selected modern literature which are appended at the end of each exercise. But the author's experience has led to the conviction that a wholly unnatural and artificial gap may easily" occur between "theory" and "practice", in the teaching of plant anatomy. To quote from De Bary's classic of 1884, "On the anatomy of plants such an indescribable amount has been written that, in a comprehensive treatise, one or many authors might be eited in reference to every word." The truth of this statement is of course self-evident today and the begimner in anatomy is often confused as well as discouraged by the wealth of detail and maze of controvers presented in many anatomical texts. In the present book, therefore. the aim has been to articulate as far as possible the practical study of laboratory material with the best of modern interpretation and theory. By this means the student, through his own work in the laboratory should be able gradually to acquire a practical basis for the critical evaluation of theory.

The material suggested for study under each exercise has been selected, as far as possible. from types of plants readily arailable to most teachers. An effort has been made to aroid rare or unusual plants and frequent reference is made to forms of economic importance to man. Wherever it seemed desirable. alternative material has been listed. 
In view of the existence of several excellent texts in plant microtechnique, special methods for the preparation of macerated tissue and permanent mounts, as well as the use of microchemical reagents, receive only brief attention in this book. Ilowerer, a few notes on these topies which may prove valuable to both the teacher and student in the use of this book are included under the "Appendix."

Since teaching methods vary, especially with respect to the nature of the record which the student is required to make of his laboratory work, each exercise contains a list of suggested drawing's and special topieal reports. This, it is hoped, will permit of selection on the part of the teacher in accordance with the time and emphasis placed on a given topic.

Whatever practical merits the present volume may possess are due to a large degree to the eonstructive eriticisms of numerous students who used the book in its previous planographed form. The exercise on sieve-tube elements has been read and criticized by Dr. Katherine Esan and Dr. A. S. Crafts for whose assistance the anthor expresses his thanks. I am also grateful for the many helpful suggestions made by Dr. Ernest Ball who served as my laboratory assistant for the past three rears. For all errors in fact or interpretation, however, the writer assumes full responsibility.

A. S. F.

Berkeley, Calif.

Oct., $19+1$

\section{SPECIAL ACKNOWLEDGMENTS}

Quotations from various texts are acknowledged as to pagination and anthor at appropriate points in this book. For special permission to reproduce these quotations, the author expresses his thanks to the following: Professor T. E. Rawlins and .John Wiley and Sons, for the quotation Irom Rawlins' Plyytopathological and Botaniral Research Methods; Tniversity of Chicago Press, for the quotation from . Jeffrey's The Anotomy of Woody Plants: Mcofiraw-Hlill Book Company, for the quotations from Sharp's Introduction to Cytolog!y and Eames and MreDaniel's Introducfion to Plant Anatomy: Longman's Green and Company, for the quotations from lriestley and scott's Introdurtion to Botany: The Maedillan Company, lor the quotations from II aberlandt's Physiological Plant Anatomy, Strasburger's Texlbook of Botany and Ilayward's The structure of Eronomic Plants. 


\section{TABLE OF CONTENTS}

Preface $\ldots \ldots \ldots \ldots \ldots \ldots \ldots \ldots \ldots \ldots \ldots \ldots \ldots \ldots$ vii EXERCISE

I. The Protoplast $\ldots \ldots \ldots \ldots \ldots \ldots \ldots \ldots \ldots \ldots$

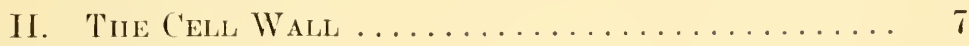

III. Meristens ................... 18

IV. Problems in the (lassification of ('ell types, Tissues and Tissue Systems in Vasculak Plants (Including Tabular summary of Main ('ella Trpes in SEed Plants) . . . . . . . 32

T. The Epinerhis . . . . . . . . . . . . . . . 45

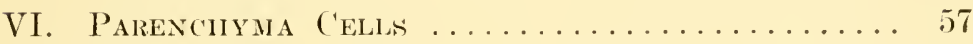

VII. Collent'hyma Cells. .................. 62

VIII. SCLEREIDES . . . . . . . . . . . . . . . 67

IX. Fibers ....................... 7 ;

X. Tracheary Elements ............... 80

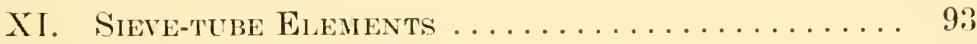

XII. The Sten ....................... 101

XIII. THE LEAF . . . . . . . . . . . . . . . 123

XIV. THE Root .................... 130

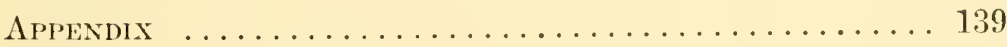

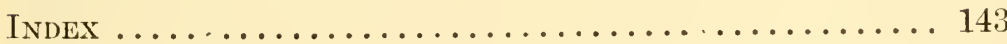




\section{General References}

The books listed below constitute the most important general references in plant anatomy and are eited by the author, wherever useful, in the specific reference lists at the end of each exercise. Additional references including recent papers and eomprehensive review articles will be found at the end of most of the exercises.

Bower, F. O., Size and Form in Plants. London, Maemillan and Company, Ltd., 1930.

Chamberlain, C. J., Gymnosperms, Strueture and Evolution. Chicago, University of Chicago P'ress, 1935.

Chicago Press, 1932.

Committec on Nonenclature, International Association of Wood Anatomists, Glossary of Terms Used in Deseribing Woods. Tropieal Woods 36:1-12. 1933.

De Bary, A., Comparative Anatomy of the Vegetative Organs of the Phanerogams and Ferns. Oxford, Clarendon Press, 1884.

Eames, A. J., Norphology of Vascular Plants, Lower Groups. New York, MeGraw Hill Book Co., 1936. New York, MeGraw Hill Book Co., 1925.

Haberlandt, G., Physiological Plant Anatomy. London, Maemillan and Company, Ltd., 1914.

Ilayward, H. E., The Structure of Economic Plants. New York, The Nacmillan Company, 1938.

Jeff rey, E. C., The Anatomy of Woody Plants. Chicago, University of ('hicago Press, 1917.

Johamsen, D. A., Plant Mierotechnique. New York, MeGralw Hill Book Co., 1940 .

Mansfield, W., Histology of Medicinal Plants. New York, John Wiley and Solls, Inc., 1916.

I'enhallow, D. P., A Manual of the North American Gymusperms. Boston, (iim and Co., 1907.

I'riestley, J. Hl,, and Scott, L. I., An Introduction to Botany. London, Longmans Green and $\mathrm{Co}_{0}, 1938$.

Rawlins, T. F., Phytopathologieal and Botanieal Research Methods. New York, John Wiley and Sons, Inc., 1933.

Sachs, J., Textbook of Botany. Oxford, Clarendon Press, 1882.

Sass, J. E., Elements of Botanical Mierotechnique. Now York, MeGraw Hill Book Co., 1940.

Sharp, L. IV., Introduction to Cytology. 3rd Ed. New York, NeGraw Hill Book Co., 1934.

Smith, G. M., Cryptogamic Botany, Vol. II. Bryophytes and Pteridophytes. New York, ileG raw IIill Book Co., 1938.

Solereder, H., Systematic Anatomy of the Dicotyledons. Oxford, Clarendon P'ress, 1908.

kotyledoner., and Meyer, F. J., Systematisehe Anatomie der Monoplete. Berlin, Geliüder Borntrager (apparently as yet incomHeft IV, 1929; II eft VI, 1930).

Strashurger, F., Ilandhook of l'ractical Botany (trans. by W. IIllhouse). 7th Ed., New York, The Nacmillan Company, 1911.

Macmillan Company, 1921. 


\section{ExERCISE I}

\section{THE PROTOPLAST}

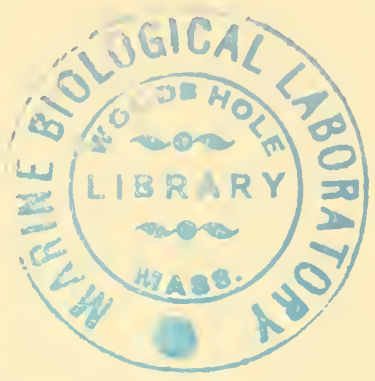

I. Introduction.-It is now a well-known fact that protoplasm. which constitutes the physical basis of all life, is organized and "subdivided" in the higher plants into small microscopic units which are termed cells. Isually each living cell, regardless of its position, form or function, consists of a wall which encloses a minucleate protoplast. Exceptions to this typical condition are furnished by the multimucleate protoplasts of certain fibers, ressels and lactiferous elements. Such coenocytes are of considerable theoretical interest with reference to the problem of the origin and significance of the multicellular plant. The socalled "Cell Theory," propounded over a century ago, regards the organism both ontogenetically and phylogenetically as a "cell republic" which has arisen by "the aggregation of a vast number of elementary individuals" or cells (cf. Sharp 1934, pp. 20-24). In contrast, the "Organismal Theory" attaches less importance to the septate condition and regards cellular structure as the result of the growth of the organism as a whole. The refinitiveness of the cell wall in the tissues of all higher plants doubtless has encouraged the continned wide acceptance of the "Cell Theory" as the more useful concept, at least in any analytical study of plant anatomy.

The term "cell" was originally applicd in 1665 by Robert Hooke to each of the numerous "cavities" observed by him in such material as charcoal and cork. Later, with the diseovery of protoplasm, the major emphasis was placed upon the living protoplasmic body and the cell wall was regarded as a "lifeless" secretion of the protoplast. At the present time, however, it seems necessary and justifiable to include both the protoplast as well as its wall under the general term of "cell." Evidence in support of this viewpoint is furuished (1) by the apparently 
intimate relationship existing between the cell wall and the protoplasm during cell differentiation, (2) by the very common occurrence of protoplasmic connections or plasmodesmuta whieh penetrate the wall at various points, and (3) by the peeuliar behavior of the wall in certain algae (cf. Anderson 1935, pp. 71-72). Many important cell types in vasenlar plants such as fibers, tracheids, vessel elenents, and sclereides consist only of the wall at maturity. Inwerer, it is entirely appropriate to designate them as "rells" sinee the loss of their protoplasts occurs during the later stages of differentiation.

II. The Cells of Plant Hairs.-The cells of many plant hairs furnish very useful material for a study of the protoplast. Because such cells are usually highly vacuolated and hence semitransparent, they may he easily studied without speeial preparation or staining. Indeer, in the staminal hains of Tradescantia. the brilliantly (oolored cell sap in the vacuome provides a splendid optical contrast for the gray eytoplasm and nueleus.

Obtain a transerse section near the tip of the stem of petmia or squash, momnt it carefully in water and examine the preparation muder low magnification. A number of semi-transparent hairs, variable in size and in the form of their terminal cells. will he seen rabliating from the edge of the section. 'Thin sections will show the mode of attaehment of the base or "foot" of the hair to the cpidemis of the stem. Selecting an minjured and straight hail, examine its component cells moler high magmification. Frequently the lower or hasal cells of the hair will prove most suitable for this sturly. By calefully regulating the light and eonstantly using the fine adjustment on the mieloseope. the moleus, with its uncleolus will be visible. In eolon, the nueleus will apperal glay and slightly opayue. (often the nucleus may appear to be imbelderl in the thin laver of cytoplasm lining the wall of the cell. ('ommonly, howerel, the nuclens is suspended in varioms positioms hy a delirate and comples netwolk of cytoplasmic stemds which extend from the peripheral eytoplasm thromeh the (elear watery a cell-sap) ol the prominent racueme of the cell. In many of the cells of the hair, small plestids may be seen in the peripheral eytoplasm and sometimes in the larger eytoplasmiu strambls. Woll-momed minjured seetions which have 
not been allowed to dry out are suitable for a study of the streaming movement of the cytoplasm as well as changes in the relative position of the nucleus in the hair-cells.

III. Plastids.-Specialized eytoplasmic bodies known as plastids are commonly found in many types of plant cells. Recent studies (cf. Weier 1938) emphasize the many unsolved problems concerning the origin, fundamental structure and activity of plastids, in particular of the photosynthetic chloroplast.

Obtain a leaf from the outer region of the terminal bud of Elodea and momt it carefully in a drop of water. Examine this leaf first under low magnification, noting that the thin lateral flaps at either side of the "midrib" are composed of only two layer's of essentially similar cells. In short, there is no mesophỵll as distinct from an epidermis. Stndy a number of cells in this leaf at varying depths of focus under high magnification. Note that all cells contain nmmerous small discoid chloroplasts which typically are in a peripheral position. Many cells, at least in healthy leaves, will exhibit cytoplasmic streaming. Careful examination will show that while the ehloroplasts are non-motile in themselves, they are passively carried in a clockwise or counterclockwise direction by the circulating cytoplasm. Often the chloroplasts are so numerous in a cell that they mask the uncleus. The latter' can be more easily observed in the more transparent teeth-like cells which occur irregularly at the margins of the leaf.

Another extremely common type of plastid is the chromoplast which frequently produces the red, orange, or yellow color of petals, fruits and certain roots. (Note: Since similar colors may be produced by anthocyanin pigments in the vacuome, the basis for color in each instance can only be determined by first hand investigation.) The role of chromoplasts in general is obscure and demands further study.

Prepare water mounts of tomato fruit, carrot root, asparagus and rose "hips," and examine them under low magnification. Note the wide variation in size and shape of the chromoplasts. According to Eames and MacDanicls (192.5, p. 13) the angular forms of the chromoplasts in the carrot (Daucus) "are largely due to the presence of crystals of coloring matter." 
IV. Ergastic Substances.-All living cells in plants contain rariable amounts of "lifeless" materials which may be collectively" designated as cryustic substances. They inchule storage products, waste material, or by-products of protoplasmic activity and in elementary botanical texts are often termed "inclusions." One of the most common examples of el'yastic substances is the plant vacuome which consists of a dilute aqueous solution of a wide range of inorganic as well as organic materials.

In addition to the vacnome, many types of plant cells contain further ergastic material in the form of reserve food such as starch, proteins and fats or oils. Perhaps the most common type of non-transitory food is starch, which occurs as grains, the size and form of which are highly specific. Obtain a thin, transverse section of the stem of Pellionia and after momnting it in water. examine the large parenchyma cells of the cortex moler lou and high magnification. Most of these cells contain starch grains which have developed within the clloroplasts. Often, "frac" ments" of the chloroplast may be seen at the broad end of the pear-shaped starch grains. The addition of dilute iorline to the section will give the blue color reaction trpieal for stareh. In the tissue of such storage organs as tuber's, fleshy roots and cotyledons, starch grains are formed by the activity of amyloplasts. These starch-forming plastick lack ehlorophyll and are to be regarded as a specialized type of lencoplast. Secure a small amomnt of fresh potato tissue and after gently teasing it with dissecting needles, momt it in water, add dilute iodine and examine under low magnification. Note the mumerous obovoid stareh grains in every cell. Examine a single starch grain muler high magnification and observe, near the smaller end of the grain, the minnte refrative point which is termed the hilum. Careful regulation of the light and patient use of the fine adjustment will usually reveal a number of more or less distinct cecentrie layers arranged abont the hilum. For comparative purposes, examine the storage parenchyma cells in the bean cotyledom, noting the difference in the form and position of the hilum in the ovoid starch grains.

A very ammon type of ereatitu smbstance in many kinds of plant cells is ealcium oxalate which appears msually in the form 
of conspicuous well-defined crystals. It is generally held that such crystals represent an exeretory product of the protoplast, being formed by the union of ealcium with oxalic acid. The recent monograph by Netolitzky (1929), however, reveals that substances other than oxalic acid may combine with ealcium to produce erystalline bodies. Comparatively little is known concerning the factors, chemical and biological, which regulate the rate and mode of crystallization, and which hence determine the form of the adult crystal. Netolitzky (1929, p. 47) concludes that in the final analysis it is "the nucleus which determines which form of erystal will be produced, perhaps by regulating the velocity of crystallization within the cell itself." Examples of the three main forms of plant crystals may now be studied.

1. Druses or sphaerraphides are compound and consist of more or less spherical aggregates of sharp pointed angular crystals, the whole mass often suggesting in form the mace-head of medieval warfare. Examine the prepared section of the stem of geranium (Pelargonium), noting the presence of druses in many of the cortical cells. Transverse sections would suggest that the crystal containing cells are solitary and isolated from one another. But in longisection, it will be seen that frequently the crystal containing cells or crystal sacs (ef. Haberlandt) are in short supposed series, each cell of which may contain a druse.

2. Raphides are long slender needle-shaped arystals which typically are arranged parallel to one another in definite bundles. Such cristals appear to be most common in the monocotyledons. According to Netolitzky (1929, p. 48) raphides constitute virtually a family characteristic in the Oenotheraceae. Obtain a single living plant of duckreed (Lemna sp.) and mount it in water. Note under high magnification that many of the transparent cells at the maroins of the "thallus lobes" contain prominent bundles of raphides. For comparison, examine under low magnification freshly-cut longi-sections of the stem of Tradescantia noting the much larger raphides, many of which may be pulled from the cells during the process of sectioning.

3. Prismatic crystals are common in vasenlar tissue but may also oceur singly, or in association with other crystal types in thin-walled cortical parenchyma cells (cf. Exercise VI). Examine prepared slides of the stem of Tilia or some similar woody 
dicotyldedon, noting the solitary crystals in the phloem parenchyma cells.

\section{Suggested Drawings and Notes.-}

1. Prepare an enlarged drawing of a single hair of either squash or petunia as seen under low magnification showing accurately the number and form of the cells of which it is composed, and its mode of attachment to the stem.

2. Draw a single living cell of a hair as it appears moler high magnification. This drawing should portray a "median optical view" and shonld include the following: cell watl, nucleus (and its visible parts), eytoplasm, vacuole, plastids. Recorrl, as labmatory notes, all observations made on cytoplasmic streaming and muclear "movement" in the material studied.

3. Select a cell from the "midrib" region of the Elorlea leaf and prepare drawings to show its appearance and contents as seen in surface and median optical riews. Describe encisely the variations in the rate and direction of cytoplasmic streaming in cells at different regions of the leaf. What may be the physiologieal significance of cytoplasmic streaming? Smmmarize the evidence indicating that plastids do not arise de nowo in the cytoplasm of plant cells [ef. Sharp (1934, pl). 69-72) ].

4. Prepare drawings to illustrate the form and the arrangement of chromoplasts in the material studied.

5. Draw cells from the cortex of Pelliomia. the potato tuber and the bean cotylerlon showing the size and form of the included starch grains.

6. Prepare drawings to show the form and position of the various types of crystals studiel.

\section{liEFERLA'PS}

1. Andersom, I). B., The Stmoture of the Walls of the Highe plants. Bot. Revies $1: 5)^{-3}-7($ i. 1935.

2. Hantes and Macl)allicls, (h. II, P. 6-1!)

3. Ilaberlandt. ('h. X, 1). 530-5)36.

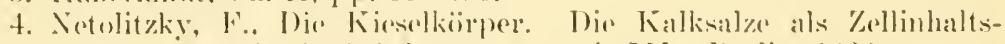

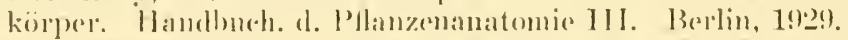

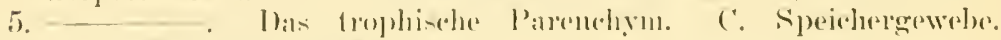
Mrirl., 11. Burlin, 1933.

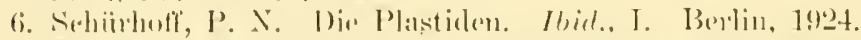

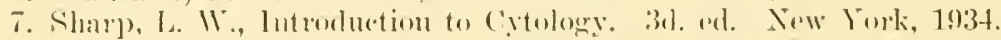

8. Wries, E., The Structure of the Chloroplat-1. Bot. Rev. $t: 4 ! 97-530$. $1 ! 38$. 


\section{Exercise 1 I}

\section{THE CELL, WALL}

I. Introduction.-Sperms, egres and certain other cells of the gametophyte of angiosperms are naked protoplasts and show no evidence of a definite cell wall. Save for these particular exceptions, the zygote and all of the succeeling generations of sporophytic cells which are derived from it are provided from the beginning with a cell wall. Indeed the rigid and often massively-thickened cell wall is frequently cited as a significant distinction between plants and animals; the cells of the latter are either naked protoplasts or else possess thin and less clearly demareated walls, features which are obviously related to the marked pliancy of many animal tissues.

The form, relative thickness and chemical nature of the cell wall, particularly the secondary wall, provide important and definite characters for separating and classifying cell types in higher plants. Consequently, a preliminary study of wall structure, together witl a brief summary of the results of moclem research constitute a natural and necessary introduction to the general problem of tissnes and cell-types, which will be critically discussed in the following exercise.

II. Plasmodesmata. ${ }^{1}$ - The protoplasts of adjacent cells of a wicle variety of plant tissues have been shown to be interconnected by delicate threads of eytoplasm, which are termed plasmodesmata (for a complete review, c.f. Meense 1941). Protoplasmic connections seem to support the idea that the cell wall, at least at certain stages in its growth, is an integral part of the living system and not simply a "lifeless" excretion of the protoplast. Knowledge as to the origin and development of plasmodesmata is meagre but there is some evidence that additional or "secondary" 'comnections may arise at different stages in ontogeny.

1 For sperial technique to demonstrate plasmorlesmata, cf. Crafts (1931). 
This problem assmmes increased interest with reference to the fate and possible renewed-formation of the plasmodesmata of certain phant cells which are believed to "slide" or push past their neighbors during differentiation (cf. Sharp 1934, pp. 15-18). The function of plasmodesmata is not entirely clear but Haberlandt (pp. 635-638) suggests (1) that they may be essential in transmitting both external and internal stimuli through plant tissues, and (2) that in storage tissue, such as endosperm, they may be "principally concerned with trans-location." Furthermore, considerable evidence has accmulated within recent years which indicates that the plasmorlesmata, especially those of sievetubes, are the channels through which certain economically-important viruses may travel. Lastly, it is probable that the high degree of correlation between the cells, tissues and organs of the plant may depend upon the presence of plasmodesmata. Livingston. (19:35) who maintains that plasmorlesmata oceur in all the living tissues of the tobacco plant, eonchudes that "the evidence presented by numerons investigators indicates that actual protoplasmic connections between cells, or plasmodesmata, are generally present throughout all living tissues of higher plants. thus establishing the orwanism as a definitely correlated entity of interconnecting protoplasts, instead of a community of separate cells."

Endosperm tissue of certain seeds provides useful material for a study of the general features of plasmodesmata. Obtain a prepared slide of the endosperm tissue of the persimmon (Diospyros) and examine the section under high magnification. Note that the greatly thickened walls are traversed by solitary or spindle-shaped groups of very delicate "lines" which are the plasmodesmata. Aecording to Qnismmbing (1925), the plasmodesmata are numerous in the walls of the endosperm of $I$. discolor and D. Ahermii while in D. lialit and D. ebrnaster "they are few, restricted and grouped at the walls. They orem single or in gromps of two, three, four, five or six, and are thicker when single and usually thimuer in gremps."

III. The Gross Layers of the Cell Wall.-Differentiation and maturation of most plant eells produce marked ehanges in the alrat and thickness of the reell wall. Yomlug cells, such as those of embryos and terminal meristems, possess relatively thin walls 
which, unless examined with special technique, appear more or less homogeneous in structure. As a cell of this kind enlarges and becomes mature, its wall naturally increases in surface. In addition, the wall may become much thicker, apparently as the result of (1) deposition of new particles of wall substance among those present, a process termed "intussusccption" by Nägeli, and/or (2) the deposition of successive plates or lamellae of wall material, a process termed "apposition" by von Mohl. The process of apposition usually occurs in a centripetal direction with reference to the first or original wall and may result in the almost complete obliteration or occhusion of the cell lumen, as is typical of certain fibers and sctereides (ef. Exercises VIII and IX).

Much confusion exists in textbooks and in the specialized research literature on cell walls with respect to the subdivision of the wall into major regions or layers. Distinctions between the sucessive layers are based upon such criteria as (1) origin, (2) appearance when viewed under polarized light, and (3) chemical and physical structure. Very recently Kerr and Bailey (1934), as a result of an extensive study of material with modern technique as well as a critieal survey of the literature, proposed a terminology which has been adopted by Anderson (1935). IIayward and others and which will be followed throughout this book. According to Kerr and Bailey, three main categories of wall layers exist :

1. The interellular "layer" or substance which is composed largely of polyuromides and is isotropir (i.e. dark or non-refringent when riewed under polarized light). Further information on the precise origin of the intercellular layer is nrgently needed but provisionally it may be regarded as being derived from the cell plate which is produced following mitosis. In tracheary elements, the intereellular layer may he more or less lignified.

2. The primury uall which consists largely of cellulose and polyuronides and is anisotropic (i.e., bright or refringent when viewed under polarized light). Kerr and Bailes emphasize that the term "primary wall" should be restricted to the original cambial wall (in the cells of xylem and phloem) and its homo- 
logues in teminal meristems and other thin-walled tissue (e.g. parenchyma). In contrast to the amorphous and "structureless" intercellular substance, the primary wall " is also characterized by possessing plasmodesmata which may be miformly distributed or agrgregated in more or less conspicuons primaly pit fields." Primary walls are capable of readjustments and reversible changes in thickness during tissuc development. Lnless special technique is adopted (e.c. polarized light) the intercellular substance and its adjoining primary walls nstally appear as a single non-lamellated partition, especially in tracheary elenents. Inder such circumstances, the term "compound middle lamella" may be applied to this complex of lignified lavers.

3. The secondary woll, which is often extremely complex, both rhemically and physically, and which is normally the most massive of all the main layers of the eell wall. Bailey and Ker. (1935) nse the term "secondary wall" to designate "the strongly anisotropic lavers of secondary thickening which are formed after a cell has attained its final size and shape." These investigators strongly emphasize that in contrast to the primary or "cambial" wall, the true secondary wall is incapable of undergoing reversible chlanges in thickness. 'This is very often the case becanse of the ultimate disinteguation of the protoplast of many cell types which possess definite secondary walls, e.g. tracheids and fibers. Aceording to Bailey and Kerr, most tracheids, fiber-tracheids, and libriform fibers in grmusperms and angiosperms possess a threelayered type of seeondary wall. The immer and onter layers. which are of relatively constant thiekness "exhibit strong double refraction and are brilliant" when examined in transverse section in polarized light between erossed nicols. The midclle layer. on the contrary, "is dark or noticeably less birofringent" and fluetuates very widely in thickness. Not all seeondary walls. however, possess the above type of stratification, exceptions being furnished hy reptain fibers and by the wall of the cotton hair. From a plusical-chemical standpoint. Bailey and Kerr conclude that the central layer of the seemdary wall ronsists of an "extremely complex and firnly coherent matrix of eellulose" within which "lignin" and a wide variety of other orwanic and inorganie substances may be deposited. The secondary wall of plant 
cells is rancly continnous over ihe entire surface of the adjacent prinary wall. In certain tracheary clements of the primary xylem for example, the secomdary wall is developed as discrete rings, spirals, bal's or as a complex metwork or mesh, while in otler cell types, well-rlefined thin areas or pits oceur.

Sccurc prepared slides of transverse sections of the stem of basswood (Tilia) and geranim (Pelargonium) and examine the parenchyma tissue of pith and cortex nuder high magnification. Note carefully the thin, apparently unstratified "componnd middle lamella', of each cell and the prominent intercellular air. spares. The very slightly thickened "walls" of these cells appear to represent the original intercellular substance and the two adjacent primary walls of the terminal meristem cells from which they originated.

Examine under both low and high magnification the extremely thick-walled bast fibers of Tibia noting the very thin. continuous componnd middle lamella, the thick, obscurely stratified secondary wall and the much reduced lumen of each cell. Occasionally, in both transverse as well as longisections, very small canal-like pits will be visible in the secondary wall.

IV. Pits.-With few exceptions, the secondary wall of plant colls is inter'upted by small cavities or recesses which are termed pits. These thin areas in the secondary wall vary widely in size. structure and arrangement and. since they exhibit some constancy depending upon the type of cell, they provide significant eriteria in comparative studies, especially of xylem cells. Pits typically occur in pairs; i.e., a thin area in the secondary wall of a given cell normally lies opposite a similar recess in the adjacent cell. Hence the term "pit-pair" designates the msual condition and is contrasted in meaning with "blind pit" which is a pit "without a complement opposite to an intercellulas" space"' (cf. Glossary of 'Terms Ised in Describing Woods, p. 5). Each member of a simple pit-pair consists of (1) the pit carity, which is the actual space within the secondary wall. and (2) the pit apcrtwe or opening into the cavity. The members of a pitpair are separated from one another by a common pit membrane which represents a discrete portion of the presumably modified intercellular substance and the two primary walls. Compara- 
tively little detailed information is available regarding the ontogeny of pits. Possibly their usual paired character is associated with the fact that at least in living eells, the pit membrame is penetrated by plasmodesmata which thus may determine the opposite position of the pits. At any event it is clear that pit-pair's arise on the primary pit fields of meristematic cells. These pit fields which are defined (cf. Glossary of Terms L'sed in Deseribing Woods, p. 4) as thimner areas of "the intereellular layer and primary walls" are observable in cambial initials as well as in the so-called primordial meristem of the shoot apex of certain seed plants (ef. Foster, 1938, 1939a, in "References"' to Exercise III). From the standpoint of function, pits are believed to facilitate the process of diffusion between adjacent cells.

Pit-pair's may be conveniently classified moder four major' types, viz. :

1. Simple pit-puirs, which are typical of cells which retain a protoplast throughout their functional life, are particularly well reveloped in parenchyma cells. In face rieu, the apcoture appears as a eircular, elliptieal or even irregular area. In macerated tissue, ${ }^{1}$ simple pit-pairs in this riew appear as refractive red points of light. A reegonition of this optical characteristic will help to distinguish simple pits from particles of protoplasm or other substances lying free in the cell humen. In sectional ricu, the carity of each member of the pit-pair is usually of equal diameter throughout and there is no overarching rim or border produced by the adjoining seeondary wall.

Obtain a preparation of maecrated secondary xylem of the stem of the trumpet-reeper (Troma rerlicans) and examine it under low magnificution noting the numerous wool parenchyma and xylem-lay parencluyma alls. These eells alle box-like in form and oceur singly or in groups depending upon the extent to which the xylem bas been macelated. Study a comnected group of parenclurnat rells moler high magnificution and investigrate the size, structure and position of the simple pit-palis as seen in surface and sectional riews. In all stmdies of this kind, it is essential to soeme aritial illumination and to nse the fine adjustment of the microseope constantly.

1 ('f. Aplendix, ple. 140-141 for the terhnigne of maecrating plant tissue. 
2. Bordered pit-pairs are typical of dead water-condueting eells, notably tracheids and ressel elements. In contrast to the previous type, the eavity of each member of the pit-pair is overarehed by a rim-like development of the secondary wall which is termed the border. As seen in face view, the pit aperture is circular or broadly elliptical. In median section vicw, the border over-arehing each pit member is apparent and, an additional struetural peculiarity is observable, namely the torus. The latter is a diseoid, eentral, thieker portion of the pit membrane which is slightly wider than the diameter of the pit aperture. The remainder of the membrane is much thimmer and suffieiently pliable so that under eertain eonditions the torus may be pressed against one or the other of the two pit apertures. To understand clearly the structure of a bordered pit-pair, it must be visualized in both face and sectional views. Referenee to Eames and MaeDaniels (1925, pp. 27-30, Figs. 15, 16, 17 and 21) and to Jeffrey (1917, pp. 5-6, Figs. 4 and 5) will prove helpful.

Obtain a preparation of maeerated xylem of the stem of Pinus and examine it under low magnification. Bordered pit-pairs are large and obvious in the traeheids, which are elongated eells with aeute or blunt tips. Select a suitable tracheid and study the appearanee of the bordered pits in face view under high magnifieation. Observe that eaeh pit appears as three concentrie outhines. The ontermost circle demareates the edge of the pit eavity, the intermediate circle represents the edge of the torus and the somewhat refractive innermost circle is the pit aperture. In many traeheids, the suceessive bordered pits are more or less clearly set apart from each other by "eye-brow" or rim-like ridges, termed crassulae. These are interpreted as "thicker portions of the intercellular layer and primary walls between primary pit fields" and in the past have been designated as "Bars of Sanio", and "Rims of Sanio" (cf. Glossary of Terms Used in Deseribing Woods, p. 4). The structure of bordered pit-pairs in seetional view can be effectively studied in macerated material if the edge of the pitted walls are turned towards the observer. In order to study critically the pit membrane and the torus, it is neeessary to examine thin, properly-stained radial seetions of pine xylem. 
3. Half-bordered pit-pairs represent "an intercellular pairing of a simple and a bordered pit" (Glossary of "Terms l'sed in Describing Woods, p. 5) and ocen when living parenehymatous cells develop in contaet with dead tracheary elements. According to a frequent opinion expressed in texts, the pit-member on the side of the living cell is simple while its mate on the side of the tracheid or ressel is bordered. Frost (1929), howerer, in a study of the nature of pitting between tracheary and parenehymatous cells in angiosperm xylem, has found that this conception has no general validity. He eoncludes that "fully bordered, halfbordered and simple pits are characteristie features between traeheary cells and vaseular parenchyma" and that "the trpe of pitting on the wall of the parenehyma cell is eontrolled laregely by the degree of specialization of the ressel or fiber which lies next to it." Obviously the whole question of pitting in plant cells demands further investigation, from both a comparative as well as an ontogenetie point of view.

Sccure prepared slides of conifer and dicotyledonous seeondary xylem and investigate under high magnification the nature of the pitting between wood parenchyma or wood ray cells and the comnected traeheary elements.

4. Testigial pit-pairs are typieal of thick-walled wood and hast fiber's. In these eells, the secondary wall is greatly thiekened and the pits are often so redueed in size and number as to appear truly "vestigial" or functionless. The restigial pit-pairs of typieal wood fibers are usnally interpreted morphologieally as redneed and highly modified borrlered pit-pairs. This eonelusion is based (1) on the belief that the wood fiber has developed plyylorrenetically from the traclieid, and (2) on the faet that a closely graded series of intermediate conditions between typical "borddered pit-pairs" and "vestigial pit-pairs" can be seen in comparing the tracheids, fiber-tracheids and fibers in the xylem of the same plant. In typical vestigial pit-pairs of wood fibers, the pit-eavities althomgh cirenlar are relatively small, the border is greatly redueed in size or absent and a torus is frequently lacking. The most rlistinctive feature of this type of pitting. however, consists in the elongated slit-lite aprotures whieh instead of being opposite (as is true of the circular apertures of the members of 
a pair of bordered pits) are crossed. Furthermore, each slitshaped aperture is comnected with the pit carity by a channel having the form of a flattened fumel (cf. Eames and MacDaniels, 1925, p. 33, Figs. 21-22). The vestigial pit-pairs of bast fibers are frequently less complex, and consist of small circular apertures and very narrow tubular eavities. Such pits are often regarded morphologically as specialized simple pits.

Obtain a preparation of macerated secondary xylem of the sycamore (Platanus) and examine it under low magnification, noting the numerous long, acuminate wood fibers. Careful study of these fibers under high magnification will reveal the characteristic arrangement of the vestigial pits with their narrow apertures and inconspicuous "halo-like" cavities. Oceasional fibers may be turned in such a way that the restigial pits or pit-pairs may be visible in sectional vicu. A study should also be made of pit structure as revealed in prepared and stained longisections through the xylem.

Make a comparative study of the vestigial pit-pairs of the bast fibers of Tilia or Platamus with the use of macerated as well as stained and sectioned material.

\section{Suggested Drawings and Notes.-}

1. Prepare drawings showing the arrangement and approximate number of plasmodesmata in a small group of connected endosperm cells of Diospyros. Briefly summarize the possible importance of the presence of plasmodesmata with reference to the trans-location of organic materials in plants.

2. Draw a group of pith or cortical parenchyma cells from the stem section of Tilia or Pelargonium showing and labeling the following: compound middle lamella, protoplast, interecllular air spaces. In what kinds of plant tissue are intercellular air spaces likely to be most prominent? Explain, from a physiological viewpoint (ef. Haberlandt, $\mathrm{Ch}$. IX).

3. Draw a group of bast fibers of Tilin as seen in the transsection of the stem, showing and labeling the following: compound middle lamella, secondary wall, and lumen. What might he the "cause" of the deeply-stained thickening's frequently visible at the common point of contact between several bast fibers? 
4. Draw several connected wood-parenchyma or wood-ray cells from the macerated xylem of Tecoma radicans, showing clearly the size, structure and arrangement of the simple pit-pairs as seen in both face and sectional view. Label the following: compound middle lamella, secondary wall, pit aperture, pit carity and pit membrane.

5. Draw, on a large scale, a single tracheid from macerated pine xylem, showing the form and arrangement of all pits (bordered and simple) as seen in face view. Label carefully. Prepare drawings based on the study of the longisections of pine wood showing scetional viows of bordered pit-pairs as well as the type of pitting between tracheids and wood rays. In these drawings label the following: compoumd middle lamclla, sceondary wall, border of pit, aperture of pit, cavity of pit, pit membrane, torus and crassulae.

6. Prepare drawings, based upon the study of macerated and sectioned wood and bast fibers of Platams and Tilia, showing the arrangement and structure of vestigial pit-pairs in both face and sectional riews.

\section{REFERENCES}

1. Anderson, D. B., The Strueture of the Walls of the Higher Plants. Bot. Rev. $1: 52-76.1935$.

2. Bailey, I. W., and Kerr, T., The Visible Structure of the Seeondary Wall and Its signifieance in Physical and Chemical Investigations of 'Tracheary Cells and Fibers. Jour. Amold. Arb. $16: 27: 3-300.1935$.

3. Bommer, .J., The Chemistry and Physiology of the Pectins. Bot. Rev. $2: 475-497.1936$.

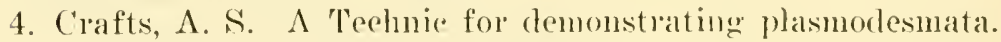
Stain Technology 4:12 $\mathbf{\tau}-129.1931$.

5. Eames and Mar Daniels, Ch. II. pp. 19-38.

6. Frost, F. H., Histology of the Wood of Angiosperms, I. The nature of the pitting between tracheary and parenchymatous elements. Bull. 'Torrey Bot. ('luh. 56:259-264. 1929.

7. Haberlandt, ('l. I, pp. 43-50; ('h. XII, pl). 635-638.

8. Harward, ('h. 1, pl). 5-11.

9. Jefiney, Cls. I. 
10. Kerr, T., and Bailey, I. W., The Cambium and Its Derivative 'Tissues, X. Structure, optical properties and chemical composition of the so-called middle lamella. Jour. Arnold Arb. $15: 327-349.1934$.

11. Livingston, L. G., The Nature and Distribution of Plasmodesmata in the Tobaceo Plant. Amer. Jour. Bot. 22 :75-87. 1935.

12. Meense, A. D. .J., Plasmodesmata. Bot. Rev. 7:249-262. 1941.

13. Quisumbing, E., Continuity of Protoplasm in Endosperm Cells of Diospyros. Bot. Gaz. $80: 439-449.1925$.

14. Sharp. L. W., Introduction to Cytology. 3rd ed. New York. 1934 .

15. van Wisselingh. C., Die Zellmembran. Handbuch d. Pflanzenanatomie, III. Berlin, 1924. 


\section{Exercise 111}

\section{MERISTEMS}

I. Introduction.-A meristem may be defined ats a specific region in the plant body where cells are engaged chicfly in division and enlargcment. Neristems thus represent embryonic arcas and can be conveniently classified according to position as apical meristems and lateral moristems. The former trpe is illustrated by the apex or "growing point" of the root and the shoot, the latter by the vascular and cork cambia. In addition, many authors recognize "interealary meristems" which are said to oecur betucen areas of permanent or mature tissue, as for example at the base of the leaf in certain monocotyledons. A more critical study of the so-called "interealary meristems" is urgently needed, however, and attention will be again direeted to this problem in the exereise dealing with the leaf (Exereise XIII).

The maintenance of meristems at certain restricted regions of root and shoot is responsible for the distinctive "open systenl" of growth characteristic of all higher plants. This consists in the continuous formation of neu tissues and new organs throughout the life of the individual. The magnitude of this type of "unlimited" ontogeny is most impressively shown in long-lived woody peremials in which each season's growth is aceomplished by the formation of new shoots, reproductive struetures, and roots, as well as by an increase in diameter of the older roots and stens. When the open system of growth is further examined, it beemes clear that there are varying degrees of "permanence" in the various meristems of a plant. Thus the apical meristems of the shoot and root in many perennials appear capable of indefinite life and activity. Aetually, of course, various factors sueh as malnutrition, insufficient water, injury, ete., may result in the leath of the shoot or root apex. Furthermore, the phenomenon of corrclation, in this case involving the relative grouth of main stem or main root as compared with its laterals. becomes a com- 
plicating factor. Another eximple of a theoretically "indefinite" or "permanent" meristem is furnished by the vascular cambium, which may continue to produce annual inerements of phloem and xylem for hundreds or, in the genus sequoia, thousands, of years. Obviously, the maintenance of an indeterminate type of meristem, such as a shoot apex or the cambium, requires that there shall be a continuous new formation or "regeneration" of the meristem as development takes place. In other words, a certain restricted portion of such meristems remains indefinitely in the embryonic state and does not pass into the zone of maturation. In contrast, the meristems of determinate organs, such as leaves and fruits, function for only a comparatively restricted period, and eventually all embryonic tissue passes into a state of maturity. Evidently these differences in the functional life of meristems are of fundamental morphological importance, but the nature of the faetors, genetical and physiological, which control them are very poorly understood at present.

From an histological standpoint, a meristem is a "tissue" composed of "undifferentiated" or meristematic cells. According to the classical viewpoint, which is still retained in many textbooks, the tissue composing meristems possesses certain distinctive jurenile characteristies which seem to demarcate it from the various types of functionally-mature "permanent" tissues. Among the "negative" character's usually assigned to meristematic tissue are: (1) the absence of intercellular spaces; (2) the absence of thiekened or pitted walls; and (3) the absence of prominent ergastic materials in the cytoplasm. If, however. undue empluasis is placed upon such morphological features, a narrow and rather arbitrary concept of "meristematic tissue" inevitably results. A good example of the restricted concept of meristem is found in Priestley and Scott's recent (1938, p. 208) "An Introduction to Botany." They state: "It is eustomary to speak indifferently of any dividing tissues of the shoot apex as meristematic, but in view of the fundamental character of the differences in cell behavior, it is proposed in this book to restrict the terms meristem and meristematic to the dense cells which are devoid of obvious water vacuoles and have no intercellular spaces between them, whilst the vacuolating cells will be spoken of as 
exhibiting vacuolating cell growth and division." Priestley's effort to demareate meristems on the basis of the absence or lack of prominence of vacuoles is not supported by comparative stulies. For example, the apical cell and its most recent segments in many lower vastular plants are highly vacuolate in character anel it is only at some distance from the summit of the apex that small "dense" cells are fomel to oceur (Eames and MacDaniels, 1925, Fig. 28; and Zirkle, 1932, taf III, Fig. 16). Likewise, in the shoot apices of Gintign biloba and Cyeas revoluta, Zamia, and Dioon crlule a more or less well-defined ecutrul group of enlarging vacuolated cells, surrounded hy smaller and more denselycytoplasmic cells is present (cf. Foster, 1938, 1939a, 1940, 1941b). These examples clearly show that the relative position and extent of "zones" characterized by the predominance of cell division or" cell enlargement are variable in the shoot apex of vascular plants (Foster, 1941a; Boke. 1941). In short, cell division and conspicuous vacuolation are not processes confined in Priestley's sense respectively to the summit and lower portion of a shoot apex. On the contrary, these processes may overlap at the same level in a growing apex. Doubtless the most significant evidence of the vacuolated character of meristems has been secured by recent studies on living tissme. The work of Bailey (1930) and Zirkle (1932) on the vascular cambinm and primary meristems respectively has indicated that all meristems are rusuoluted, and furthermore, that the form of the "racuome" varies within wikle limits at different seasons of the year and at different stages of growth in the same type of meristem.

From the preceding brief critique it shonld be evident that it is impossible in the light of present knowledge to frame an adequate "Alefintion" of meristematic tissue. On the contral'y, it seems increasingly elear as investigation procecels, that we have to deal with varions and possibly distinct types of "meristem," at least from a physiological viewpoint. How the organization and growth of meristems is related to the orderly progressive differentiation of tissues from apical or lateral meristems constitutes one of the most wallenging problems in modern botany. Further insight will come when the results of romparative observation are ehecked by experimental sturlies. It seems likely that 
the complex phenomena of regeneration or regressive differentiation, when they are better understood, may be expected to shed important light on the fundamental nature of meristems. ('f. Bloch, 1941 ; Simnott and Bloch, 1941a, 1941b.)

In the present exercise, a preliminary study will be made of the apical meristems of root and shoot, and of the vascular cambium. Further experience with these meristems as well as with the cork cambium will be gained particularly in the exercises devoted to the anatomy of root, stem, and leaf.

\section{Apical Meristems.-}

1. The shoot apex. The classical investigations of C. F. Wolff (1759) on bud development showed that new leaves and new stem tissues are traceable in origin to the delicate tip of the shoot. Wolff designated this region as the "punctum regetationis," a term which has been rather freely translated as the "growing point." Despite the widespread adoption by anatomists of the expression "growing point," this term carries an inaccurate implication and in the present book will be replaced by the more appropriate and non-committal designation of "shoot apex." This decision is based upon the fact that the chief significance of the so-called growing point is that it represents the region of initiation of the primary organization of the shoot, rather than a localized area or "point" of "growtl." As a matter of fact, if "growth" is regarded as an increase in size of cells, tissues, and organs, this process is obviously at a minimum in the "growing point."

Great variation obtains with respect to the form and dimensions of the shoot apex of seed plants. As seen in median longisection view, the apex commonly has the form of a mound or low dome. In Elodea, Myriophyllum, and Hippuris, however, the shape of the shoot apex is that of a slender, blunt-tipped cone (cf. Louis, 1935, pp. 126-130 and Pl. IX, Figs. 77-78). The apex of dicotyledons with decussate phyllotaxis (e.g., Syringa, Lonicera, Ligustrum, etc.) is particularly suitable for developmental studies because the initiation of each pair of foliar structures is preceded by a notable and symmetrical expansion of the terminal meristem. Since this process is repeated each time a pair of leaves is produced, the apex exhibits a rhythmical alternation of 
what Schmidt (1924) callecl "minimal" and "maximal" areas (cf. also Louis, 19:35, P'l. II, Figs. 20-21; and Cross, 19:37, Figs. 10-11). This situation emphasizes the fact that the form and the dimensions of the shoot apex are likely to vary depending upon whether an active or dormant apex is measured as well as upon the particular phase in shoot development which is under examination. Extremely few careful measurements have been made of the shoot apex of seed plants, and no generalizations are possible at present. Apparently, however, the angiosperms typically possess rather small apices which range in diameter from $90 \mu$ in certain grasses to $500 \mu$ in some of the palms. Possibly 130-200 " may move to represent a frequent range in diameter of the apex in dicotyledons (Boke, 1940). The width of the shoot apex of some conifers, of Ginkyo biloba. and of Zamia. slightly exceeds that of "typieal" angiosperms. But in the Sago Palm (Cycas revoluta Thunb.), the shoot apex may attain the relatively enormous diameter of 3.5 millimeters, a dimension greatly exceeding that recolded for any vascular plant (ef. Foster, 1940). The nature of the relationship between size and form of the apes, on the one hand, and the morphology and primary anatomy of the shoot, on the other, is olviously (ommplex and awaits further comparative studies for its solution (Bower, 19:30), Ch. XII; Foster, 1939b, 1940, 1941a, 1941b).

When a thin median lomgi-section of the shoot uper of an angiosperm is examined muler the microseope, two principal zones or regrions are usually distinguishable, viz.: (1) the turica, which comsists of ome or more discrete smperficial layers of cells. and (2) the empus. which is a "core" occupring the center of the apex and exhibiting an irregular on "landom" arrangement of cells. 'The differences in coll arrangemont in tumical and eorpus

1 In loth of these zones, the cells are relatively small and in sectional view appear "isodiametric" in form. Little is known, however, alsont the shatpe of such "ells when regarded as three-dimensional struetures. Ac"oriling to Priestley and Seott (1935 pl). 201-202) macerated reells of the apex "appear as bather irregular, many-sided figures, the facets of which alle mainly hexigonal of scuatre." By compressing spheres of plasticine, these investigators whtained 12-sided hodies which they assmme are similar in form to meristem cells. They conclucle that "the shape of the eells is thus explatimed as the nitural result of the growth and division of plas. tic boties mater mutnal pressure," (For futher information on the prob-

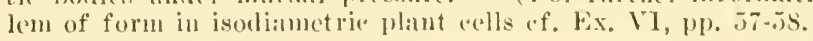


result from differences in the direction of growth and plane of cell division in these zones. In the tunica, surface growth accontpanied by repeated anticlimal divisions predoninates, resulting in the maintenance at the summit of the apes of a more or less regular and constant series of shell-like layers. On the sides or flanks of the apex, however, the distinctness of the inner tunica layers is somewhat lost, chiefly because of the periclinal and oblique divisions which appear in them during the intiation of foliar structures and lateral buds. In contrast to the lumica, growth in volume is characteristic of the corpus, and the sequence in the successive planes of cell division is variable and usually very irregular. Tumica and corpus thus represent two interdependcut zones in the shoot apex, and their extent and behavior may be expected to fluctuate, depending upon the systematic position of the plant in question as well as upon the phase of development of the plant itself. Modern studies have shown that the number of tmic layers varies from one in grasses and Scrophularia nodosa to as many as five or six in Hippmis. Tnfortunately, no detailed survey along broad systematic lines has yet been attempted, so that the phyletic significance, if any, of differences in the number of tmic layers is quite olsscure at present. The classical "Histogen Theory" of IIanstein (1868) attempted to assign specific destinies or "prospective values" to the various layers and to the central core of the shoot apex. In contrast, the concept of tunica and corpus, which originated with Schmidt (1924), is non-committal with respect to the nature of the tissues produeed by these two zones. Recent studies justify Schmidt's cautious viewpoint. In certain angiosperms [e.g., Vibumum rufidulum. Cross (1937)], the corpus is exclusively concerned with the production of the pith, while in other plants Carya Buckleyi var. arkansana, Foster (1935); Morus alba, Cross (1936), the provascular tissue and inner region of the cortex, as well as the pith, originate from the corpus zone. In Hippuris and Myriophyllum, the corpus gives rise to the central pith-less stele of the axis (Louis, 1935, pp. 128-130, Pl. IX, Figs. 77-78), simulating in this respect the histogenesis characteristic of many roots. The "prospective significance" of the various lavers of the tumica also varies, particularly with respect to their role in the 
initiation of leat and bud primorelia (Foster, 19:36). While the outermost tumic layer very commonly behaves as a "dermatogen" and produces exclusively the epidermal s!stem of leaf and stem, the apices of Triticum and lecue furnish interesting exceptions. In these grasses, the foliage leaf originates largely if not exchusively from the single tumic layer which exhibits both periclinal and anticlinal divisions at the early phases of foliar development. Doubtless similar conditions will be discovered in other angiosperms.

$\Lambda$ proper study of the form and structure of the shoot apex in seed plants and of the origin of primary stem tissues and leaves is only possible if both longitudiual and transecrse serial sections are available. Since the choice of bucl material will depend upon many factors, no detailed deseription of a speeific shoot apex will be made in this book. Insteald. sngrestions as to the advantages and special features of several a vailable types of apices will be given. With the information presented in the earlier portions of this exereise and in the literature cited, the student should have no diffieulty in interpreting the general organization of any angiospermous sluoot apex. The monnd- or clome-shaped form of apex, with several tunic layers, is well illustrated in such genera as Coryu, Morus, Rhododendron. Acaciu. Syringa, Rosa, Sambucus, and Hetienthus. Aside from minor variations, the origin of leaves and the differentiation of provascular strands ("plo-cambinm”) and "rib meristen" are similarly shown in all of these genera. "Rib moristem." a concept developed by schiiepl (1926), is a type of primiry meristem which in a longi-sectional riew of a shoot apex appears as a tiscme (omposed of vertical filamentous oromps of valcuolating-dividing cells. This meristem trpically differentiates into the parencluyma tissue of eortex and pith. The stendel conse-shaped apices of Elodea or Hippuris are instrnetive, providing median longi-sections are examined. Apices of these general ale paldirularly useful in remonstrating the mode of origin of the small leaf primordia from the tunica zone, as well as slowing the carly denalseation between eortex and the pitl-less stele. Preparations of the shoot apices of monocotyledons shomlal also be studied. The apex of Tradescentio is of interest since the demalleation between 
tunica and corpus zones is not always clear. luthermore, the relation of rib meristem and provascular areas to the young nodes and internodes is clearly shown in this gents (ct. liudiger, 1939, and Ball, 1941). For comparative purposes, a study should also be made of the shoot apices of various grmosperms. Here the choice of material is often rery limited and hence specific recommendations may be of little valne. But the apices of vigorous growing shoots of Piccu, Abies, or Cedrus are readily seetioned and all agree in the absence of the tmica-corpus type of zonation characteristic of angiosperms. Instead, a small group of initials is situated at the summit, from which arise two major tissue-areas or zones, viz.: (1) an onter peripheral zone, which produces the leaves, epidermis, cortex, and provascular tissue, and (2) an inner or central tissue zone which prodnces exclusively the pith. The possible phylogenetic significance of this type of apex is discussed in several recent papers (Foster. 1939h. 1941a; Cross, 1939, 1941). Apices of Ginkgo (Foster, 1938) and of some trpe of cycad (Zamiu, Johmson. 19:39; Cycrs revoluta, Foster, 19:39a, 1940; Dioon, Foster. 1941b) are also worthy of the student's time, particularly because of the interesting phylogenetic as well as morphogenetic problems which are raised by their mique growth and structure.

2. The Root Apex. The apex of the root differs fundamentally from that of the shoot in the presence of a root cap. The latter is a thimble-shaped or conical structure which occupies the true phrsical apex of the root and which acts as a "buffer" for the delicate meristematic tissme which is thus subtcrmimal in position. Great variation exists with respect to the histogenetic relationshi]s between the root cap and the subterminal meristem. Indeed. the differences are sufficiently evirlent to make necessary the designation of a number of "types" of root apices which are distingmished (1) by the mode of origin of the eap, and (2) the relation of the varions so-called "histogens" to the origin of the primary tissue regions in the root proper. (Haberlandt, 1914, pp. 89-94, and Hayward. 1938, pp. 44-48.) It is an interesting fact that while the highly deterministic scheme of Hanstein (1868) has been largely ahandoned for the shoot apex, the structure and growth of the root apex is still generally inter- 
preted in terms of the "histogen theory" (Hayward. 1938, pp. 44-48; von Guttenberg, 1940). While it is true that the absence of foliar structures in roots makes it relatively easy to determine the point of origin of a given tissue, it may well be questioned whether Hanstein's concepts are any more justified for the root than for the shoot. It seems evident, at any erent, that a broad systematic survey of the structure and behavior of the root apex in angiosperms and gymmosperms would remove the problem from the highly formalized position which it now oecupies.

Secure serial longitudinal and transierse sections of some of the principal "types" of root apices, viz. (1) the "grass type," charaeterized by the possession of a discrete meristem termed the calyptrogen whieh exchusively propagates the root eap, and by the origin of "dermatogen" and "periblem" from a common initial group; (2) the "Allium type" in which, aceording to Hayward (1938, p. 46) "the root cap, epidermis, and eortex arise from a common group of initials two cell layers in thickness. and within this zone is a sharply defined plerome;" (3) the "Helianthus" type whieh is believed to represent the most common type in dicotyledons, and in which "the plerome and periblem are sharply defined; and outside the latter is a eommon initial layer which produees the root eap and the epidermis", (Hayward, 1938, p. 46, and Haberlandt, pp. 89-30, Fig. 19); and (4) the "Pisum" type in which a transverse initiation zone is the eommon point of origin of root eap as well as the primary tissues of the root. In this type, which is fomm in Cucurbita and many Leguminosae, well-defined "histogens" are not recognized (Hayward, p. 47, Fig. 17). Regardless of "type," calceful inspection of median longi-seetions under low and high megnification will reval the successive "zones" of cell origin, cell elongation, and coll maturation. The "rib moristem" of the onter peripheral region of the root tip is particularly useful in studying these zones, because of the extremely regular arrangement of the eell rows and the gladual changes in size, shape, wall thickness, and degree of vacuolation of the eomponent rells. Note in contrast the relatively short "zone of transition" from the "ealyptrogen" (or its equivalent) to the onter senescent cells of the root cap). 'The marked differenees in the rutc and duration of 
cell division respectively in root cap and the body of the root, present an important but entirely obscure morphogenetic probleris.

\section{The Vascular Cambium.-The term "vaseular cambium"} is applied to vertical strips or narrow cylinders of enlarging and dividing cells which are lateral in position and which give rise to the secondary phloem and secondary xylem tissue-systems. The vascular cambium is properly regarded as a "secondary meristem" since its activity is responsible for the ardition, at some distance from the apex of root or shoot, of new or secondary vascular tissues to the original or "primary" conducting system which in turn had its origin in the provascular meristem or "procambinm." In many heshaceous angiosperms, especially many of the monocotyledons, and in most of the lower vascular plants, cambial activity is reduced or absent and the vascular strstem is therefore largely "primary" in character. But in woody angiosperms and in the gymnosperms, the primary tissues of stem and root are short-lived and become destroyed or buried by the more massive secondary rascular system formed by the cambium.

The most significant of modern studies on the structure and growth of the cambium have been made by Bailey (1920, 1923, 1930), who has studied both fixed as well as living cells in a wide range of gymmosperms and angiosperms. From a morphological standpoint, the cambium may be regarded as a single layer of cells in which tangential (i.e., periclinal) divisions predominate during the propagation of phloem or xylem. Two principal types of initials ocem in the cambium, viz.: (1) the fusiform initial, which as seen in tangential longi-sectional view is prosenchymatous in form and in certain plants, aceording to Bailey, may attain the enormous length of $5,000 \mu$, and (2) the vascular-ray initial, which is a much smaller cell and is more or less isodiametric in form. The fusiform initials form such elements as tracheids, vessels, fibers, wood-parenchyma, and sievetubes, while the ray initials are points of origin and propagation of the radially-disposed phloem and xylem rays (cf. Barghoorn. 1940). One of the many interesting features of cambial cells is their highly vacuolate character, which is only evident when liv- 
ing tissme is critically studied with the aid of such vital stains as "Neutral lied.", Bailey (1930, p. 67T) states: "Nolnal (ammbial initials ale comspichonsly vacmolated. Indeed certain of them are as highly vacuolated as plant hairs, which are commonly cited as illustrations of extreme specialization of the protoplast in fully differentiated cells. The classical conception of non-racuolated meristems. and the varions physiological generalizations that have been deduced therefrom should be abandoned." .Just low the form, wall structure, varnome, and peruliar methods of cytokinesis in cambial initials are related to the derivation in opposite directions of such heterogencous tissue systems as phloem and xylem is not yet clear. It would seem evident. however, that here. as with comparable publems at the root and shoot apex, experimental studies (e.g., tissue cultures and transplantation) may ultimately illuminate much of the olscurity of this important problem.

The most instructive and realistie views of the vascular anubium are secured from a study of living material which may be stained with neutral red (cf. Appendix, p. 142). With the aid of a sharp, heary knife and a sliding microtome, it is possible to obtain nseful tangential, ladial, and transwerse sections of the rambium and its recent phloem and xỵlem derivatives. The "ambium of Pimus is a good gymospermous type witlo wreatly elomgated non-stratified fusiform initials while Robinin illustates a dientyledonons type with shorter. rather evidently stratified fusiform initials.

\section{Suggested Drawings and Notes.-}

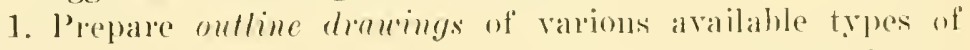
angiospermous and grommospermons shoot apices. In eatels outline, indicate diagrammatically hy means of legends, the position

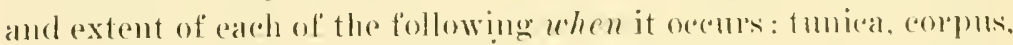
provascular stramel, rib meristem, pith, cortex, lealt primordim, axillary bud primordimm, peripheral tissue zone (in apex of grommosperms), (entral tissue zone (in apex of cymmosperms), initial zone.

2. Prepare an ontline drawing of an angiospermons shoot apex, filling in all the cells of the tmica and eorpus zones and 
of the youngest leaf primordia. Also show the form and arrangement of the cells (1) in a small portion of a provascular strand, and (2) at several successively older regions of the rib meristem. Label carefully all important struetures.

3. Prepare an outline drawing of one of the available types of angiospermous root apices, showing diagrammatically and labelling the following: root cap, subterminal meristem, region of elongation, region of maturation, epidermis, cortex, stele.

4. Select one of the trpes of root apices and fill in the cellular details of the root cap, the calyptrogen (if present) and the socalled "histogens" of the root proper, i.e., "dermatogen," "periblem." "plerome." Label all parts of the drawing.

5. Prepare drawings of the cambinm of Pinns and Robinia showing its appearance as seen in the transverse, radial and tangential planes of section. In the drawings of transverse and radial sections, a small portion (i.e., several cell layers) of the adjacent phloem and xylem tissue shonld be shown.

\section{REFERENC'ES}

1. Bailey, I. W., The Cambimm and Its Derivative Tissues, TIT. $\Lambda$ reconnaissance of rytological phenomena in the cambium. Amer. Jour. Bot. $7: 417-434.1920$.

2. - - The Cambium and Its Derivative Tissues, IV. The increase in girth of the eambinm. Amer. Jour. Bot. $10: 499-509.1929$.

3. — - The Cambium and Its Derivative Tissues, V. A reconnaissance of the vacnome in living cells. Zeitseh. für Zellforch. u. mik. Anatomie. $10: 651-682.1930$.

4. Ball, E., Mierotechnique for the Shoot Apex. Amer. Jour. Bot. $28: 2333-243.1941$.

ז. Barghoorn. E. J., Jr., Origin and Development of the Iniseriate Ray in the Coniferae. Bull. Torr. Bot. C'lub $67: 30$ : 328. 1940.

6. Bloeh, R., Wound Healing in IIigher Plants. Bot. Rer. $7: 110-146.1941$.

7. Boke, N. II., Histogenesis and Morphology of the Phyllode in Certain Species of Acacia. Amer. Jour. Bot. 27:73-90. 1940.

8. - Zonation in the shoot apices of Trichocereus spachinuss and Opuntin cylindrien. Amer. Jour. Bot. 28: 6.j6-664. $19+1$.

9. Bower, F. O., Size and Form in l'ants. London, 1930. 
10. Cross, G. L., The Morphology of the Bud and the Development of the Leaves of Viburnum rufidulum. Amer. Jour. Bot. $24: 266-276.1937$.

11. _ _ - The Structure of the Growing Point and the Development of the Bud Scales of Morus alba. Bull. Torr. Bot. Club $63: 451-465.1936$.

12. - , The Structure and development of the Apical Meristem in the Shoots of Taxodium distichum. Bull. Torr Bot. Club $66: 431-452.1939$.

13. Cryptomeria japonica. Amer. Jour. Bot. 2\&:573-582. 1941.

14. Eames and MacDaniels, Ch. III.

15. Foster, A. S., A IIistogenetic Study of Foliar Determination in Carya Buckleyi var. arkansana. Amer. Jonr. Bot. $22: 88$ 147. 1935 .

16. — Leaf Differentiation in Angiosperms. Bot. lier. $2: 349-372.1936$.

17. - - Structure and Growtl of the Shoot Apex in Ginkgo bitoba. Bull. Torr. Bot. Club 65:531-556. 1938.

18. - - Structure and Growth of the Shoot $\Lambda$ pex of Cycus revoluta. Amer. Jour. Bot. $26: 372-385.1939$ a.

19. - - Problems of Structure, Growth and Erohution in the Shoot Apex of Seed Plants. Bot. Rer. 5:454470. 1939b.

20. —, Further Studies on Zonal Structure and Growth of the Shoot $\Lambda_{\text {pex }}$ of Cycus revoluta. Amer. Jour. Bot. $27: 487-501.1940$.

21. - - Comparative Studies on the Structure of the Shoot Apex in Seed Plants. Bull. Torr. Bot. Club. 68: 339-350. 1941a.

22. ——, Zomal Strueture of the Shoot Apex of Dioon edule. Aner. Jour. Bot. 285:5i-56t. 1941b.

23. II Iaberlandt, Ch. II.

24. Hanstein, J., Die Scheitelzellgruppe im Vegetat ionspunkt der Phanerogamen. Festschr. Niederrhein. Ges. Natur. Helikunde: 109-14:3. 1868.

25. IJayward, pp. 12-15; 44-47; 63-67; 77-85.

26. Johnson, M. A., strueture of the Shoot Apex of Zamiu. Bot. Gaz. $101: 189-2013.1939$.

27. Louis, J., L'ontogénèse du système condueteur dans la pousse leuillée des Dietoylées et des Gymmospermes. Lal ('ellule 4t: $87-172.1935$.

2. P. Priestley, J. H., and sicott, I. I., An Introduction to Botany. London, 1938. 
29. Rüdiger, W., Dic Sprossvegetationspunkte einiger Monokotylen. Beitr. Biol. P'fl. $26:+(01-4+3.1939$.

30. Schmidt, $\Lambda$., II istologische Studien am phaneroganen Vegetationspunkten. Bot. Arehiv. 8:345-404. 1924.

31. Schüiepp, O., Meristeme IIandbuch d. Pflanzenanatomie. IV. 1926.

32. Simnott, E. W., and Bloch, R., Division in Vacnolate Plant Cells. Amer. Jour. Bot. $28: 225-232.1941$ a.

33. - $\longrightarrow$, - The Relative Position of Cell Walls in developing Plant Tissues. Amer. .Jonr. Bot. 28 :607617. 1941b.

34. Von Guttenberg, H., Der primäre Ban der Angiospermenwurzel. Ilandb. d. Pflanzenanatomie. VIII. Berlin. 1940.

35. -, Der primäre Bau der Gymnospermenwurzel. Ibid.. Berlin, 1941.

36. Wolff, C. F. Theoria generationis. Halae, 1759.

37. Zirkle, C. Vacuoles in primary meristems. Zeitsch. für Zellfors'h. u. mik. Anatomie. $16: 26-47.1932$. 


\section{ExERCISE IV}

\section{PROBLEMS IN TIIE CLASSIFICATION OF CELL TYPES, TISSEES, AND TISSUE SYSTEMS IN VASCULAR PLANTS}

I. Introduction.-Despite the rast amount of information which has acemmlated during the present century regarding the cellular structure of higher plants, the nomenclature and classification of rell types and "tissues" is still in a confused and uncertain state. Doubtless much of the diffieulty arises from the absence in plants of the high degree of structural and physiologieal individuality which eharacterizes the tissues of higher animals. For example, certain so-ealled "permanent" or" "adult" tissnes, such as parenchyma, collenchyma, and epidermis. may "secondarily" revert to a meristematic state and prodnce tissues or structures quite different from themselves. Furthermore. it is difficult or even impossible to draw a clear morphological demareation between adjacent "permanent" tissues in many instances. A good example is furnished by the gradual intergradation between collenchyma and parenchyma tissue in the cortex of many stems. As a consequence of these and other diffienlties, the term "tissue" in Plant Histology has been used. sometimes in a broad sense, sometimes in a restrieted sense, depending upon the relative importance attributed to position. origin, structure, or function. Sachs (1875, p. 68) adopted in the first place a broad concept by stating that "in the widest sense every agoregate of cells which obeys a common law of growth (usually, howevel, not miform in its action) may be termed a tissue." A similar idea is found in Strasburger's Textbook (1921, p. 41), where a tissue is defined as a "eontinuous aggregation of cells in intimate mion." Other definitions of "tissue" are less general in character and introduce, in various ways, the idleas of origin, specific cell structure, and function. For example, Eames and MaeDaniels (192.). p. 50) define a tissue 
as "a continuous organized mass of cells, usmally similar in or'igin. and essentially alike in form and general function." Hayward (1938, p. 11) adopts a similar attitude by contending that "strictly defined, a tissue is a group of cells of common origin having essentially the same structure and performing the same functions." In these definitions, community of origin, continuity and similarity in structure and function are essential attributes of the cells of any "tissue." Haberlandt (1914, pp. 56-72), in contrast, has approached the problem from quite a different point of view. He assmmes that the differentiation of specific cellagrigegates or "tissues" in plants is "mainly the outcome of division of labor, and that consequently the most characteristic features of each tissue are those which are most intimately connected with its physiological activity.' Haberlandt's concept is thus essentially physiological or functional, and the ontogenetic and phylogenetic aspects of tissues are more or less completely dismegarded.

It is necessary to emplasize that the wide differences in the concepts of "tissues" outlined above have much more than an historical significance. On the contrary, these differences nnderlie the varied schemes of tissue classification found in modern botanical texts and continue to influence the study of comparative histology and anatomy. For these reasons, the following critical resumé of the most important early as well as recent schemes of tissue classification is offered as a guide for the student in the interpretation and evaluation of modern histological literature. In addition, it is hoped that this critique may serve to emplasize the need for a complete re-examination of the fundamental assumptions mpon which these attempted elassifications inevitably rest.

\section{Systems of Tissue Classification.-}

1. Sach's classification. Sachs assumed that, in the phylogenetic development of the higher plants from simple multicellular forms, a distinction gradually arose between the outer lavers of cells or "tissue", and the internal mass. The latter" finally differentiated strands of cells surrounded by "fundamental" tissue. The final result is seen in the "primary" structure of the leaf, stem, and root, which consist, according to Sachs 
(1875, pp. 77-78), of three principal s'ystems of Tissues, viz.: (1) the Epidormal system, unter which are grouped the epidermal and cork layers; (2) the Fascicular s'ystem, which consists of the variously-arranged xylem and phloem; and (3) the Fundamentul Tissue s'ystem, which Saehs defined as "those masses of tissue of a plant or of an orcan which still remain after the formation and development of the epidermal tissne and the fibro-rascular bundles." Sachs (op. cit., p. 10:3) emphasized that his elassification was not concerned basically with the forms of cells "hut with the contrast of different systems of tissue, each of which may eontain the most various eell-forms." It is lastly" of interest to note that Sachs did not attempt to demarcate rigidly "permanent" and "meristematie" tissue but on the contraly emphasized the ability, especially of the epiclemal and fundamental systems, to regress to the state of a "formative" or" dividing tissue.

Sachs' classification of the adult vegetative tissues of higher plants into three main groups is appealing in its apparent simplicity and practicability. That it does indeed possess considerable pedagogical value is shown by its adoption (with or without minor ehanges) in such modern texts as Simott (1935) and IIolisch (1936). From a more technical standpoint, Saehs' elassification is also used by Jeffiey (1917, pp. 8-13), who emphasizes, however, that the structural boundaries between the three tissue systems are more evident in lower than in higher vasenlar plants. Furthermore, the limits of the systems appear less sharply defined in the stem than in the "more conservative" leaf and root. In organs where secondary growth is prominent, the boundaries between the vascular and fundamental systems may disappear and "in such eases the linits of the tissues ean only be inferred from comparative and developmental anatomy.", The chief whjection which has heen repeatelly raised anainst Saehs' elassification is concerned with the indefunte phrsiologieal as well as structural charactersties of the "Fundamental Tissue System." In some organs, this system may eonsist laregely of parenehyma, but many other eell types no tissiles may be present. The fundamental tissue system. as IJaherlandt (1914. 1. 712) states, includes "ireen photosy"nthetic parenchrma. colorless water-tissue, 
storage-parenchyma, mechanical strands and cell-masses, endodermal layers, and the multifarious tissues which make up pericarps and seed coats. No one, therefore, will venture to maintain that "ground-tissue" constitutes a "whole of definite physiological character."

2. Haberlandt's classification. Probably no seheme for classifying plant tissues has been carried out so consistently from a single point of view or in such detail as IIaberlandt's "Anatomico-Physiological Classification.', According to Haberlandt's viewpoint, the "principal function" should be the sole guide in the designation of any specific tissne "system." The "principal function" of a tissue is defined as "that for'm of physiological activity with which its most obvions and important anatomical featmes are correlated." The application of this idea resulted in the distinction by Haberlandt (1914, pp. 71-72) of twelve "anatomico-physiological tissue systems," each of which is typified by one major or "principal" function : e.g., absorption, condnetion, protection, support, ete. With reference to the merits of his seheme of classification, he contends that "the anatomicophysiological definition and arrangement of tissnes provides the broadest and most natural of all syrstems of tissue classification, since from this point of view the plant-body is regarded not merely as a more or less complex aggregate of formal elements. but also as a living organism, composed of a number of functional units and engaged in a corresponding number of physiological activities, whel all contribute to the safety and welfare of the whole."

Haberlandt's high estimate of the value of his method for classifying tissues has been amply justified by its wide adoption in elementary as well as more adranced treatises on plant histology. Tsehirch (1889) and Palladin (1914), for example. follow Haberlandt's system with little modification and Moliseh (1936) champions its merits for the adraneed student. In this country, the anatomico-physiological classification has likewise proved popular and is ntilized, in a somewhat simplified for'm, in such a reeent compendium as Hayward (1938). But one of the most significant illustrations of the prestige and influence of Haberlandt's ideas and elassification is furnished by the ambi- 
tious "Handbuch der Pflanzenanatomie" which treats of the varied phases of anatomy in nonographic form. Linsbaner, as the original editor, states in the first rolume of this encyclopaedic work, that, aside from certain disagreement in details, the principles of Haberlandt's physiological anatomy will be adopted. In this same volume, an able and penetrating discussion of the various concepts and classifications of tissues is given by Lunde. gairdh (1922). This author, while agreeing in principle with the anatomico-phrsiological method of elassification, emphasizes the need for a cautious and critical approach to the problem, sinee "the physiological-anatomieal systems only indieate the normal combination of strueture and function and obviously do not permit of any teleological conclusions as to the method of their origin." Lmudegardh (op. cit., p. 17.j) proposes the following anatomico-physiological conspectus of tissue srstems, vi\%:

1. The Coherent Tissme Systems (oomposed of eontinuons ("ell aggregates).

1. The Formative or Meristematic Tissmes.

13. The Mature T'issues.

1. Systems with dynamic functions, e.g., assimilation, respiration, storage, absorption, etr.

2. Siptems with statie functions, e.e... protection, mechanical support, ete.

II. The Disperse Systems (omposed of isoluted cells or eell"roups distributed as "islands" in the midst of various "coherent sistems").

1. Stomata (i.e., guard and aneessory bells).

B. Organs of Pereeption.

('. Reproductive Apparati.

1). Idioblasts (e.g., isolated stone eells found in tloe nesophyyll of certain foliage leaves such as Camcllia).

Two principal objections have been advanced against Ilaberlandt 's soldeme of classifeation and the fundamental assmomptions upon which any anatomico-phỵsiological șystem is based. First of all, Haberlandt's system is eonstructed with respect to the nature of the "principal function" of each tissue system. How- 
ever, many tissues or cell types carry on more than a single function. In such instances, a distinction between "principal" and "subsidiary" function appears somewhat arbitrary. In other words, certain types of cells might with equal justification be classed in more than one of the anatomico-physiological "systens." Furthermore, as Lundegårdh admits, the principal function of a tissue (e.g., storage of reserve starcly) can only rarely be deduced from observation only. IIence, any anatomico-physiological classifieation has a provisional character and is destined to be changed or modified in the light of new experinental data.

In the seeond place, the objection is raised that in such a scheme as Haberlandt proposes, confusion results becanse of the disregard of the origin of cells and tissmes. For example, in IIaberlandt's classification, epidermal and cork cells, although differing fundamentally in origin, are grouped for physio-topographical reasons under the "Dermal" or protective system. Conversely, guard cells and root hairs, while having a common origin from the embryonic surface cell-layel or " protoderm," are classified because of functional differences in the "Ventilating" and "Absorbing" systems respectively. In short, as Haberlandt $(o p$. cit., p. 70$)$ emphasizes, to the phrsiological anatomist "the homologies of tissues are of no interest . . "' in defining and classifying the various tissues of the plant body; " . . . his concern is solely with analogy." Whether such a viewpoint leads to a "natural" insight into the evolutionary derelopment of plant tissues is open to serious question. Jeffrey (1917, p. 8) says in this regard that "from the point of view of the doctrine of descent, funetional features are of less significance, since it is precisely these which are the most readily modified and as a ronsequence furnish the least valuable indieations of the course of evolutionary development in any given large group."

3. Eames' and MacDaniels' classification. In contrast to the schemes of Sachs and IIaberlandt, Eames and MacDaniels base their elassification of tissues on mothor of devclopment. From this standpoint, tissues "whiels are developed directly or indirectly at the growing points hy eell division in several or many planes" are termed primary tissues. On the other hand, tissues which "are formed largely by eell dirision in a single plane, 
indiviclual cells consecutively forming many new cells, which because of this method of formation lie in definite rows," are designated as secondary tissues. They originate from cambiu of various types (e.g., the rascular cambinm and the cork cambiums). This ontogenetic riewpoint is based on the idea that since "parenchyma" is phylogenetically the primitive tissue, meristem, which is likewise "unspeeialized" and "parenchymalike," constitutes the natural foundation upon which to base a classification of adult specialized tissues. This ontogenetic seheme of chassification is very useful in emphasizing the difference between the "primary" and "seeondary" growth and structure of the stem and root in gymnosperms and many dicotyledons. But, from the point of view of cell structure, there is often little or 110 morphological difference between certain cell types comnon to both primary as well as secondary tissues. Thus, for example, fibers which differ little in form or structure ocenr in the cortex and pericycle ("primary tissue" regions) and in the secondary phloem.

Eames and MacDaniels further attempt to sublivide "permanent" tissues into two main groups, viz. (1) simple tissues. such as parenchyma and collenchyma, which eonsist of a single cell type and are thus structurally homogenous: and (2) complex tissues, such as xylem and pluloem, which eonsist of several distinct types of cells and hence are structurally heterogencous. Such a distinction appears to have a very restricted practical. value, although it may be theoretically justifiable on phylogenctic grounds. First of all, very few of the eell types present in higher vascular plants ocrul as "simple tissues." Parenchyma, it is true, is often "homogeneous," but not infreumently idioblasts, in the form of blanched scleseides, are seattered among this "tissue." From Lundegardh's standpoint, these idioblasts would collectively compose a separate "diffuse tissue system." Furthermore, the elements of a "simple tissue" (e.g., fiber's or parenchyma cells) may likewise be present as components of a "complex tissue" (e.g., "phloem parenchyma," "phloem fibers," "xylem parenchyma," "xỵlem fiber's”).

The preceding critical resumb hats attempted to point out briefly the advantages as well as the apparent defects of certain 
outstanding schemes of tissue classification. Future progress may be expected when our insight into the developmental and functional potentialitics of the various types of cells has been increased. It seems clear that the fields of pathological and experimental plant anatomy are destined to contribute largely to a more natural grouping of cells and cell aggregates. Weber (1929), who has characterized all previous anatomy as "cell wall anatomy," contends that a firm basis for the distinction of cell types and tissues must depend upon a better knowledge of protoplasm, with less attention to the morphology of dead and fixed cell walls. In his view, this requires the careful observational and experimental investigation of living protoplasts, which may be "physiologically" distinct although "morphologically" identical. This new approach, which Weber terms "Protoplasmic Plant Anatomy," is still in its infancy, but undoubtedly a better knowledge of structure will appear as our knowledge of the behavior and potentialities of living cells and cell groups increases [cf. the reviews by Bloch (1941) and White (1941)].

Since all methods for classifying plant tissues are open to objection, the writer has adopted a non-committal and "practical" attitude in this book. Instead of following any one scheme of classification, the emphasis is placed first of all upon the salient morphological features of the principal types of plant cells. These cell types recur in various regions, "tissues" and organs of the higher plants, and a thorongh knowledge of their form, structure, development, and presumable function(s) must con. stitute the necessary analytical approach to anatomy. If such knowledge is gained through practical laboratory studies, the student should be in a position to study with some degree of independence the comparative anatomy of such organs as the stem, root, and leaf.

In the appended table an effort is made to summarize the important features of the main types of plant cells. Reproductive cells (spores and gametes) as well as specialized secretory or sensitory cells have been deliberately omitted. No pretense of "completeness" is therefore made, but it is hoped that the table may serve its purpose as a basis for the analytical study of plant structure. 


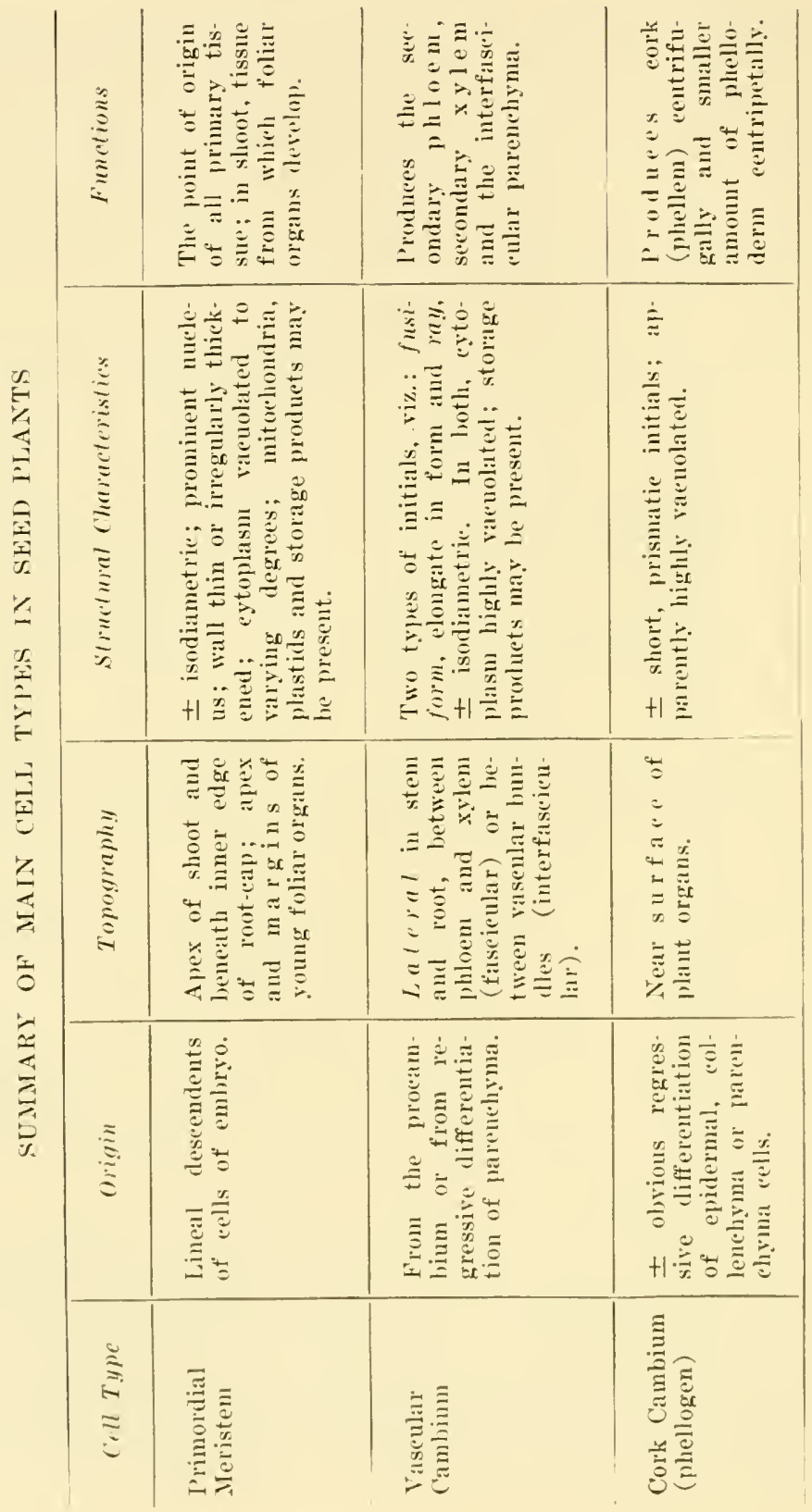




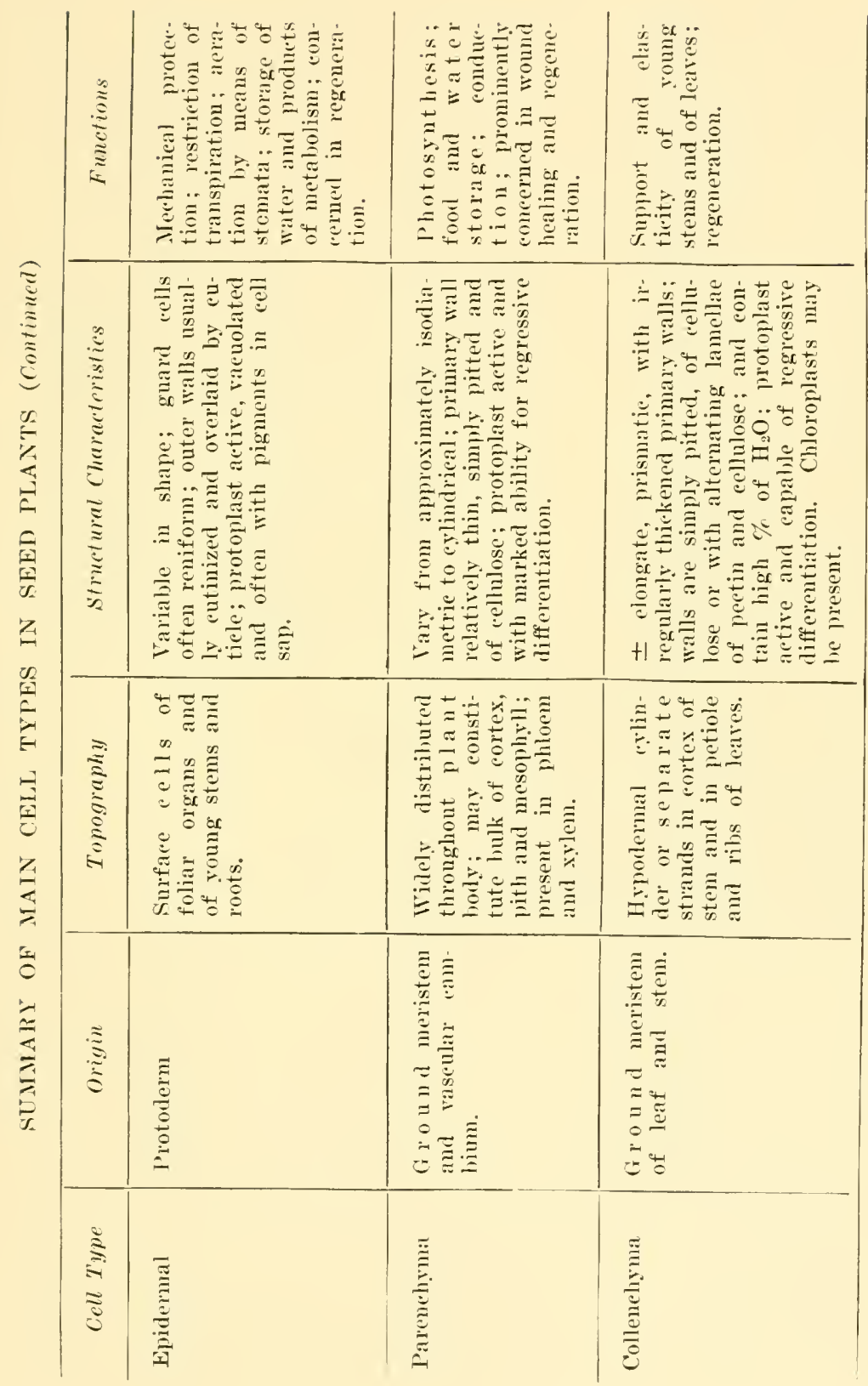




\begin{tabular}{|c|c|c|c|}
\hline 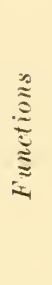 & 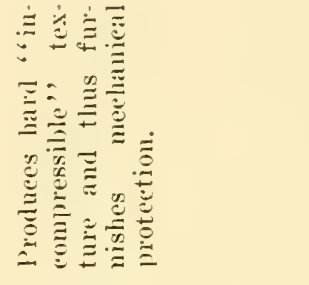 & 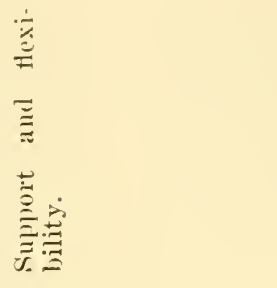 & 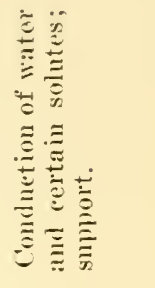 \\
\hline 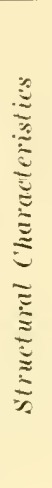 & 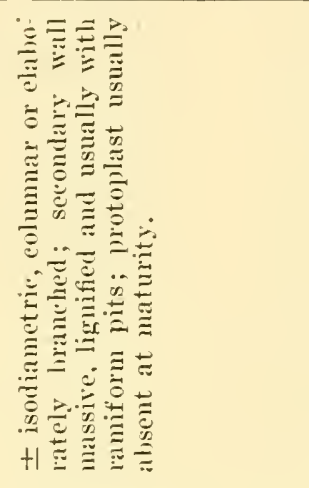 & 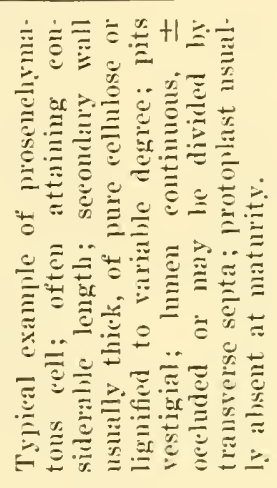 & 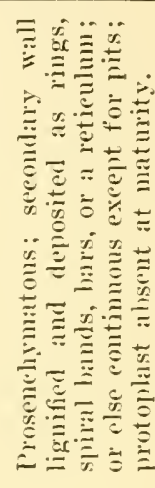 \\
\hline 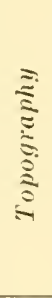 & 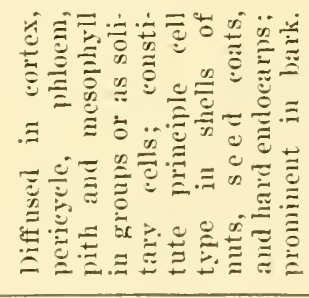 & 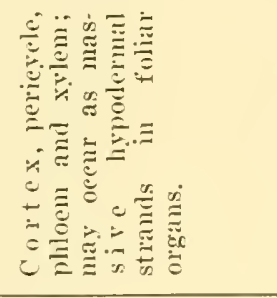 & $\frac{\Xi}{i}$ \\
\hline$\stackrel{\widetilde{\widetilde{\sigma}}}{\tilde{\sigma}}$ & 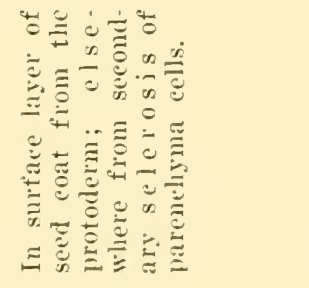 & 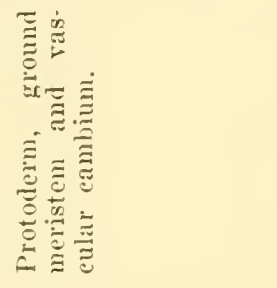 & 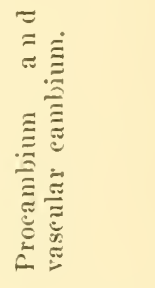 \\
\hline 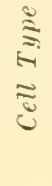 & 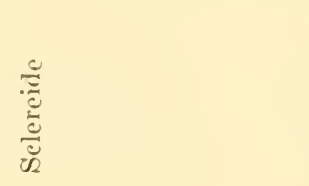 & 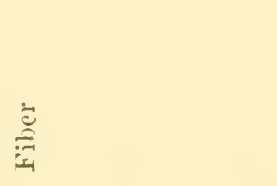 & 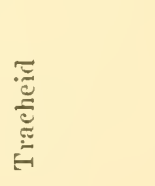 \\
\hline
\end{tabular}




\begin{tabular}{|c|c|c|c|}
\hline & 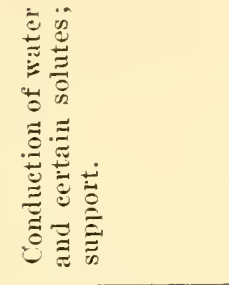 & 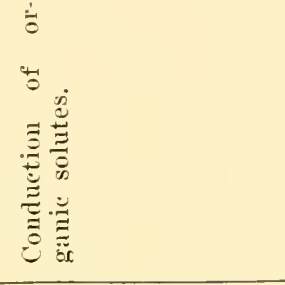 & 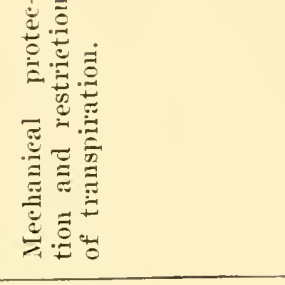 \\
\hline 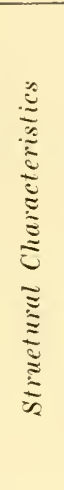 & 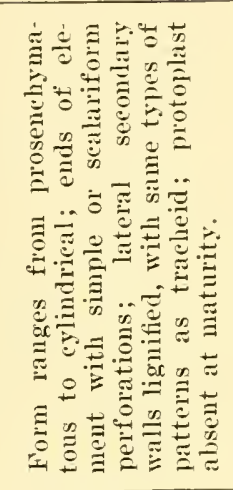 & 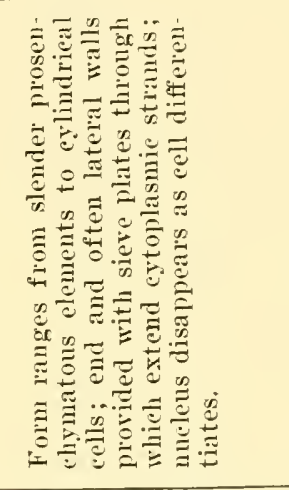 & 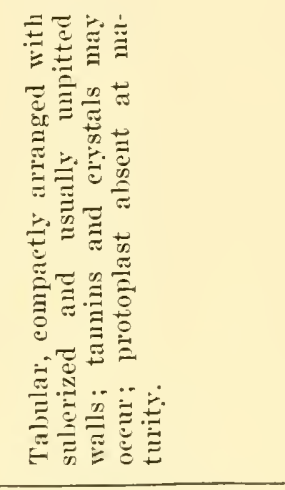 \\
\hline 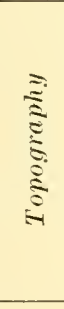 & 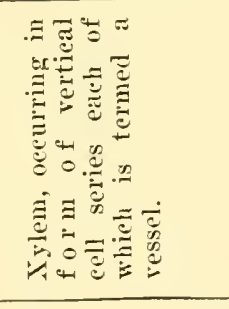 & 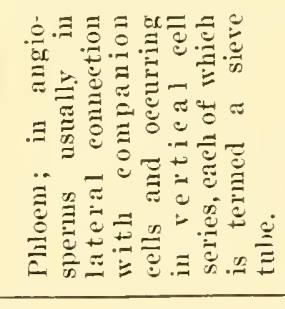 & 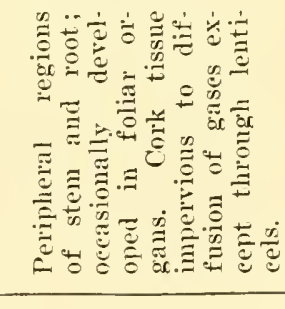 \\
\hline$\tilde{\Xi}$ & 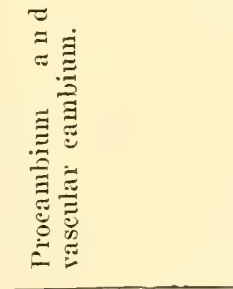 & 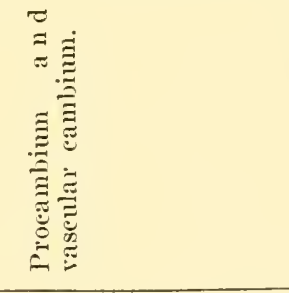 & 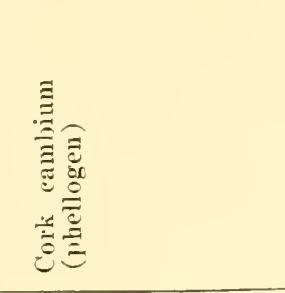 \\
\hline 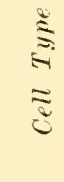 & 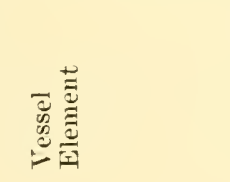 & 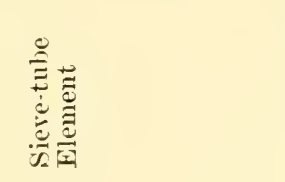 & 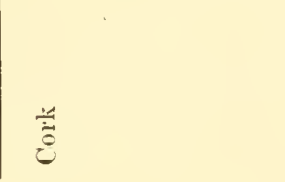 \\
\hline
\end{tabular}




\section{REFERENCES}

1. Bloch, R., Wound Healing in Higher Plants. Bot. Rer. $7: 110-146.1941$.

2. Eames. A. J., and MacDaniels, L. H., An Introduction to Plant Anatomy. New York, 192.5.

3. Haberlandt. G., Physiological Plant Anatomy. Trans. of th German Ed. London, 1914.

4. Hayward, H. E., The Structure of Economic Plants. New York, 1938.

5. Jeffrer, E. C., The Anatomy of Woody Plants. Chicago. 1917.

6. Lundegårdh, II. Zelle und Cytoplasma. IIandb. d. Pflanzenanatomie. I. Berlin, 1922.

7. Moliseh, II., Anatomie der Pflanze. Jena, 1936.

8. P'alladin, W. I.. Pflanzenanatomie. Trans. of 5th Russian Edition. Leipzig n. Berlin, 1914.

9. Sachs, J., Text-Book of Botany. Oxford, Clarendon Press, 1875.

10. Simnott, E. W., Botany, Principles and Problems. New York, 1935.

11. Strasburger's Textbook of Botany. 5th Englislı Ed. Lsmdon, MacMillan and Co., Ltel., 1921.

12. Tschirch, A.. Angewandte Pflanzenanatomie. W'ien и. Leipzig, 1889.

13. Weber, F., Protoplasmatische Pflanzenanatomie. Protoplasma $8: 291-306 . \quad 1929$.

14. White, P. R., Plant Tissue Cultures. Biol. Rev. $16: 34-48$. 1941. 


\section{Exercise $V$}

\section{THE EPIDERMIS}

I. Introduction.-From a purely topographical viewpoint, the term cpidermis may be applied to the superficial layer of cells in young stems and roots, and in foliar structures. Since the epidernis represents, in this sense, the point of dircet contact between the plant and its exterual enviromment, it is not surprising that this "tissue" exhibits considerable diversity in its structure and functions. Haberlandt (p. 102) has proposed a restricted physiological definition of the epidermis which would inchude only" "those superficial cells or cell-layers, the histological features of which clearly indicate that their principal function is that of a primary tegumentary or dermal system." According to this riewpoint, absorbing hairs and stomata would be excluded on physiological grounds from the epidermis. But as Linsbauer (1930, pp. 4-5) has clearly pointed out, it seems hardly justifiable to place the chief emphasis on the function of "protection" in the definition of the term epidermis. On the contrary, the cells which are morphologically a part of the epidermis may perform varied functions, important among which are mechanical protection, restriction of transpiration, water storage, aeration, storage of various metabolic products, absorption and photosynthesis. To subdivide such a "continuous" layer as the epidermis into various "anatomico-physiological systems" is more likely to result in confusion than is the retention of the broader topographical-morphological concept expressed above. The ontogenetic development of the epidermis likewise justifies its interpretation as a "morphological unit," since its origin is traceable to an external embryonic layer or "protoderm." In lower vascular plants and in many gymmosperms, the protoderm of the shoot appears some distance from the summit of the apex as a superficial layer derived from the periclinal division of the segments of the apical initial or initials. But in many angio- 
sperms the protoderm is directly continuous with the outermost tunica layer or "dermatogen" of the shoot apex (for further details, ct. Exercise III). In roots, the motoderm likewise is demarcated from the internal meristems in the vicinity of the apex. Iayward (pp. 45-47) has recently summarized the more important "types" of root apices from the standpoint of the way in which the protoderm ("dermatogen') is related to the development of root cap, cortex and stele.

In the majority of seed plants, the epidermis is a miseriate layer of cells which clothes the "primary body." Aside from the epidermal appendages or trichomes, which will be studied later in the exereise, the eommon cell types composing this layer are epidermal cells and the guard colls. The epidermal cells, although exhibiting considerable variation in size, shape and arrangement, are usually closely jomed with one another, thus forming a sheet of eells which is pierced only by the intercllular spaces or pores found between the guard cells. An exeeptional type of epidermis occurs in petals. however, since here intercellular spaces are found between ordinary epidermal cells. Aecording to Eames and MacDaniels (pp. 284-28.5) these "spaces do not open to the outer air, however, since they are covered in all cases by the cuticle." Epidermal cells are roughly "tabular" in form and especially in the laminae of dicotyledomons foliage leaves, have a characteristic undulute contour when seen in surface view. $\Lambda$ protoplast is normally retained and a great variety of ergastic substances such as anthocyanin pigments, tamnins and oils ocen in the cells. Epidermal cells exhibit to a notable extent an ability for regressive differentiation. This is shown not merely by the origin in certain plants of the plellogen in this layer (Eames and MacDaniels, p. 210) but especially by the important role of epidermal cells in the production of adventitious bud-primordia (cf. Crooks, 1933. Naylor and Jolmson. 1937, McVeigh, 1938, and Naylor, 1940).

With the exception of roots and the submersed portions of aquatie plants, the outer walls of the epidermis are eovered by a sheet of waxy material which is termed the cuticle. This waxy layer is contimuous, except for the stomatal openings, and serves to restrict the loss of water from plant organs. The thickness of 
the cuticle is highly variable, in some organs being a hardly perceptible "film" while in other instances (e.g., fruits and certain types of leaves) it is extremely prominent (Eames and MacDaniels p. 37, Fig. 24). The wells of epidermal cells vary in their structure and ehemical composition. Typically, the outer tangential wall directly beneath the euticle, is the most heavily thickened of all the walls and the inner-tangential wall the thinnest. Often the radial wall taper's in thickness towards the inner tangential wall. Simple pits are common in the radial and inner walls of epidermal cells. According to IIaberlandt (p. 102) the innermost zone of the outer wall usually consists of "unaltered cellulose", and is followed externally by layers of wall substances which contain varying amounts of eutin. The recent work of Anderson (1934), however, has shown that in the leaf of Clivia nobilis, the thick outer wall of the epidermal cells shows "two distinct zones of cutinization." The outermost zone is devoid of cellulose or pectin while "the immer zone of entinized wall consists of a series of cellulose lamellac separated by layers of pectic material, both of which are impregnated with cutin. The inner entinized zone may be in direct eontact with the protoplasm of the cell or may be separated from the protoplasm by a sceond zone of cellulose and peetic materials." It is clear from this work that a thorough study of the process of cutinization in epider'mal walls of various plants is urgently needed.

The continuity of the epidermis, especially of foliage leaves and young stems, is interrupted by minute openings or pores which are termed stomata. Each stoma represents an intereellılar space between a pair of highly specialized epidermal cells known as guard colls. As seen in surface view, guard cells are very frequently creseent-shaped with their concave surfaces adjacent to the slit-like pore. In contrast to ordinary epidermal cells, the walls of guard cells are uneven in thickness, often with ridge- or flange-like extensions at the edges of the pore. Furthermore, guard cells usually contain prominent chloroplasts. Since stomata play such an important role in the processes of respiration, photosynthesis and tranpiration, much attention has been devoted to the "mechanism" by which the stomata are "opened" and "closed." In general, clianges in the width of the stoma. 
are regulated by the relative degree of turgor in the guard cells. which in turn causes slight alterations in their shape. When the guard cells are turgid, the width of the pore is at a maximum while closing of the aperture oecurs when the turgor of the cells decreases. A discussion of the rariation in the construction of the walls of guard cells and of the physiological factors influencing the turgor movements of these cells, however. is beyond the reope of this book (ef. Haberlandt pp. 445-47T). Guard cells originate hy the anticlinal division of certain protoderm cels into two dissimilar daughter cells. In the simplest condition, one of these rells functions as an initial cell and by an anticlinal division directly produces the two guard cells; the of her daughter cell meanwhile differentiates into an ordinary epidermal cell. But many deviations from this simple type of stomatal development oceur, especially with reference to the formation of the subsidiany cells. The latter differ in form and arrangement from the neighboring epidermal cells and are believed to cooperate physiologically with the guard cells in regulating the width of the stoma (for information regarding the varions modes of stomatal development ef. De Bary, pp. 39-45. Porterfield, 19:37. and Yarbromol, 19:34).

A study will be made first of the structure of the uniseriate epidermis. Later in this exereise a brief explanation and direcetions for study of the multiple epidermis and of trichomes will be given.

\section{Material for the Study of the Uniseriate Epidermis-}

1. The hulb-scale of the onion (.1llimm (epa). Remove. with foresps. a small strip of epirlemis from the outer or abaxial. surface of the bulb-scale and mount it calrefully in water. Ender low magnification, note the rather orderly arrangement of the "rectangular" or tabular epiclermal cells. Stomata, which may be abortive or "abnormal" in appearance, are occasionally presont in this material. Inder high magnification. it will be seen that the indial walls of the ephermal colls are provided with numeroms small simple pits. Because of the comparatively small ratial depth of the epidermal cells, morelei are readily seen. The eytoplasm is highly valuolate and offen is actively streaming of moving within many of the colls. Small greentish-yellow bodies. 
which may represent rither Iencoplasts or ergastic material are also observable. T'o study the cuticle and the structure of the walls of the epiclermal cells, cut thin trans-sections of the bulbseale, and mount them in a .1'\% solution of neutral red. ${ }^{1}$ If these sections are not overstained, the nentral red will be confined largely to the protoplasts and the walls will be clearly demarrated. Similar trans-sections, when gently heated in a solution of Suclan IV,? are particularly suitable for a study of the cuticle which will appear under high magnification as a brilliant reel layer continuous over the onter walls of the epidermis.

2. The leaf blarle of the geranium (Pelargonium) or the "German Iry" (Senicio mitunoides). Remove small strips of the lower (abarial) epidermis and mount some in water, other's in a $.1 \%$ solution of nentral red. Note especially the characteristic undulate contours of the epidermal cells and the numerons stomata. If the germinm epidermis is used, the relationship of the numerous multicellular huirs ean be readily studied.

3. The leaf of $T$ ris sp. Mount strips of the epidermis in water as well as in neutral red and examine carefully under low magnification, noting the regularly-arranged stomata and the elongate form of the epidermal cells. Careful focusing will show that the guard cells with their stomata are slightly sumken beneath the surface and are overarched by the ends of the epidermal cells adjacent to them. Thin trans-sections of the epidermis should also be secured and treated with neutral red and sudan $1 \mathrm{~V}$. These sections will reveal the thick cuticle and the prominently thickened onter tangential walls of the epidermal cells.

4. Prepared slides of trans-sections of the leaf-blades of lilar (syringa vulgaris) and corn (Zea Mays). Trans-sections cut hy hand are often too thick to permit of an acemate examination of the structure of the walls of guard cells. For this reason, a supplementary study should be made of the guard cells as seen in thin stained sections of the forms listed above.

III. The Multiple Epidermis.-In the leaves of rertain angiosperms, particularly in members of the families Pipcraccac. Begomiaceate and Mortecae, some or all of the cells of the original

\footnotetext{
1 Cf. Appendix, p. 142.

2 Cf. Appendix, p. 142.
} 
uniseriate epidermis may experience tangential divisions which result in the formation of a multiple or multiseriute epidermis. According to the resume of the literature given by Linsbauer (19:30, pr. :38-4:3), the first tangential divisions leading to the development of the multiple epidermis oceur at a relatively late stage in leaf ontogeny; in Ficus, for example, as the leaf is expanding and after its stipules have fallen away. Such divisions apparently occur first near the middle portions of the lamina and progress towards its margins. Often the tangential divisions are so regular as to produce a tissne eomposed of thinwalled cells arranged in radial rows. But antielinal divisions may also oeenr in the eells thus obseming the point of origin of the tissue. It shonld be apparent from these facts that the concept of the "multiple epidermis" is based fundamentally upon its direet origin from the surface cell layer and not upon its histology or functions. This is important because much confusion has been produced, especially in the literature of physio. Iogieal anatomy, by failing to distinguish between a true multiple epirlermis and the varions types of "hypodermal" tissues which originate and develop independently of the epidermis. The ehief function of the multiple epidermis is water storage and a brief discussion of its artivities in this direction are summarized by linsbauer (1930, pp. 41-43). According to the earlier work of Pfitzer which is ontlined hy Linsbaner, water-storing tissue of epirlermal origin may in Peperomia perestinefolie attain a thickness of 14-15 layers and thus represents abont 7 times the thickmess of the other leaf tissies.

\section{Material for the Study of the Multiple Epidermis.-A} typical example of a multiple epidermis is fomd in the leaf blade of the "ommon "pubber plant" (Ficus elasticu). As early" as 1827, the German botanist Meyen observed that during the formation of the multiple epirlermis in this speeies, eertain of the original epidermal cells fail to divide tangentially but instead become enormously distended inwardly and finally protrude into the molerlying palisade parenchyma. During this process of distention, al anions peg-like invagination develops from the outer fangential wall into the cell cavity and eventually beeomes 
coated with a crystalline mass of ealcium carbonate. This curious ingrowtl of the cell wall, together with its eovering of calcium carbonate is termed a cystolith and the cell in which it occurs is known as a lithocyst. (Cf. the recent work of $A$ jello, 1941.) Obtain a trans-section of a portion of a living leaf-blade of Ficus clastica and examine it under low and high magnification. The multiple epidermis on the upper (i.e., adaxial) surface consists of several layers of cells the outermost of which are small, compact and overlaid by a prominent cuticle. These cells thus exhibit the features of a normal "uniseriate epidermis."

In contrast, the inner cells of the multiple epidermis are relatively large and because of their shape, their cellulose walls and the presence of intercellular spaces suggest resemblance to cortical parenchyma tissue. Notice that the cells are not aligned in radial rows because, during their formation, both anticlinal as well as periclinal divisions have occurred. A careful inspection of the walls of these cells under high magnification will reveal numerous simple pits. At intervals large sac-like lithocysts will he seen, protruding into the adjacent palisade parenchyma. These distended cells have arisen directly from the original surface cells of the leaf blade. Each lithocyst, unless injured in sectioning the leaf, contains a eystolith with its knob-like end covered by a crystalline mass of calcium carbonate. Introduce a few drops of hydrochloric acid under the cover-glass and observe the rapid dissolution of the calcium carbonate. This is accompanied by the evolution of small bubbles of carbon dioxide.

V. Trichomes.-This ter'm may be used in a collective sense to designate the diversified types of epidermal appendages such as hairs, scales, colleters and water vesicles. Despite the "endless" variation in the form and structure of trichomes (cf. De Bary, pp. 5\&-66, and Netolitzky, 1932), these structures originate from the cxtension or subdivision of protoderm cells. Trichomes are therefore, morphologically, a part of the epidermis in contrast to emergences (e.g.. the prickles on the stem of Rosa, Ribes, etc.) which consist of cells derived not only from the protoderm but also from deeper hypodermal layers (cf. De Bary, p. 58, and Eames and MacDaniels, p. 1 and p. 2, Fig. 1). 
'The morphological distinction between trichomes and emergences is of further interest in those cases where hairs or scales ale borme upon an emergence (C'ooper. 19:32).

Trichomes furnish a rich field for morplogenetic investigations becanse of their great diversity and because their superficial position and relatively simple structure facilitate ontogenetic stuclies with living material. As an introduction to the problems in this field, a brief characterization of the fon commomest "trpes" of trichomes is now given, viz. :

1. Hairs. In form, hairs are thread-like in appearance and are either unicellular (e.g., root hairs) or multicallular. The latter type of hair may cousist of a single series of colls, terminating in an arute terminal cell or a glandular cell; or the hair may be branched in various ways. In some plants, the hairs ale composed of several layers of cells and are termed shag-huirs. such multiseriate hairs are often borne mpon an energence (De Bary, pp. 64-6., and Fig. 21c). Two general regions may be distmglushed in a hair, viz.: (1) the foot, which is the portion lying within the epidernal surface and which is often dif ferent in form fonn the adjacent epiclermal cells, and (2) the borly which is the pontion extending away from the epidermal surface. Oecasionally, a given epidemul suface develops but a single type of hair (e.c., root hairs). More commomly. especially in leaves, several different morphological types of hains occur sicle by side on the same epidermal area.

2. Soales. These trichomes comsist of a plate of cells and are

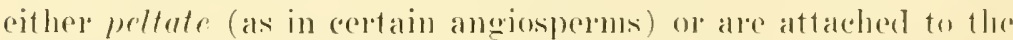

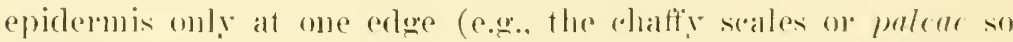
(ohataderistic of many ferms). Suales in the genelat shepherdie

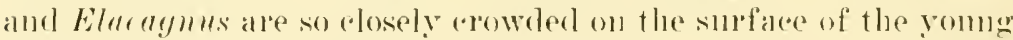
stem and the leaves that they puoduce a trpical "scurfy" appeal'ance.

3. Colleters. On many foliar organs, particulary on hud scales and stipules and on the follage leaves of reptain weneral

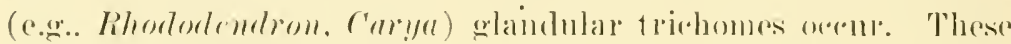
structures were originally termed colloters hy llanstein (1868). Colleters (.omsist of a short, often multicellulal stalk bearing an expanded disc or knoh of seretor!y cells. The characteristic 
sticky axudation found on eedain lolial structures is secreterl from colleters (cl. Foster, 1929, pl). 457-45s).

4. Hatre tesicles or bladders. Trichomes of this type consist of greatly distended epiderunal cells which presumably are of physiological importance as reservoirs for water (cf. IIaberlandt, p. 116). In the so-called "Ice Plant" (Mescmbryanthomum crystullinum), the water vesicles are so large and so numerous that the leaves and young stems appear to be covered with minute translucent beads of "ice."

\section{Material for the Study of Trichomes.-}

1. Hairs. Obtain thin trans-sections of the petiole of the geranimm (Pelargonimm) and after momting them in water, ${ }^{1}$ study carefully the structure of the unicellular and the multicellular umbranched hairs. Note the relatively thick onter walls of the body of these hairs. The foot, especially of the multicellular hair. consists of an enlarged bulbous cell, separated by a transverse wall from the body, and surrounded by a cireular group of more or less elevated subsidiary colls. The true relationship of the subsidiary cells to the foot of the luair is clearly seen in thick trans-sections of the petiole as well as in strips of epidermis remored from the lower surface of the lamina. Note that certain of the hairs are glundular, teminating in a single large secretory cell filled with dense, yellowish-brown erwastic material. Excellent material for a stmdy of multicellular branched hairs is afforded by the leaves of various members of the Malvaceae, where typical stcllate hairs ocenn. Each hair of this type consists of a number of radiating micellular "branehes" which have arisen from the subdivision of a singte epidermal cell. Further illustrations of multicellular branched hairs are provided by the leaves of mullein (Terbascum Thapsus). Scrupe a small amount of hairs from the leaf into water, carefully tease them apart with dissecting needles and examine under low magnification. Note that these complex hairs are "dendroid" in form; i.e., each hair consists of a main "axis", (made of a rertical series of cells) and whorls of radiating micellular or bicellular "branches.", Trans-sections of very young mullein leaves are

\footnotetext{
1 Cf. Appendix, pp. 139-140.
} 
very instructive in showing ralious stages in the ontogeny of these hairs. The leaf-blade of the sycamore or huttonball tree (Platanus) likewise will provide examples of dendroid multicellular laain's.

2. Scales. Serape a small quantity of trichomes from the leaf of shepherdiu or Elucugnus into a drop of water on a shide and examine under low magnification. In Shepherdia two extreme types of peltate trichomes will be seen, viz. (1) Stellate hairs. consisting of a delicate stalk bearing ten or more distinct radiating unicellular "branehes," and (2) scales which are gray-yellowish brown in color, lobate and consist of a plate of many" cells. Note under high magnifieation that not all of the cells composing the disc-like scale radiate from a common center. Aceording to the recent ontogenetie studies of Cooper (1932) this condition results from nnequal and oblique dirisions which may oceur near the onter end of certain of the cells early in the development of the scale.

3. Colleters. The bud scales of the horse-ehestnut (Aesculus Hippocustanum) provide exeellent material for a study of typical colleters. C'ut thin trans-sections of the imner seales of a winter hud and monnt them in water. Inder low magnification note that the abaxial surface of the seale in particnlar is densely rovered with colleters. Additional or alternative material for a study of colleter's is furmished by the bud scales of various speceses of Rhododemiron.

4. Wreter eesicles. Obtain several thin trans-sections of the petiole of the "Tee-Plant" (IIssembryanthemum crystallimum.) and examine them in water under low magnification. The adult water vesicle appears as a large clear hemispherical eell whieh projects ontwardly from the general epidermal surface. Inder high magnifieation, a molens, seanty eytoplasm and small plastids may be detectable in the bladders. If the concave adaxial surface of the petiole of immature leares is examined, varions stages in the origin and expansion of the water vesicle may be seen.

\section{Suggested Drawings and Notes.-}

1. The miseriate epidermis. Prepare earefully labeled drawines to show the structure, in both surface and trans-sectional 
views, of the epidermis of Allium, P'elargonim (or Senccio) and Iris. In drawings of the surface riew, emphasize the shape and arrangement of the stomata with reference to the epidermal cells. In drawings of trans-sections, indicate clearly the extent and relative thickness of the cuticle, the thiekness and pitting of the walls of the epidermal cells and the relation of the epidermal cells to the underlying tissues of the leaf. Also dra a single stoma from stained trans-sections of the leaf of Syringa or Zea to show the structure of the guard cells and the form and extent of the substomatal cavity.

2. Multiple epidermis. Prepare a large drawing to show in detail the structure of the multiple epidermis of the leaf of Ficus clastica. Include in this drawing a lithocyst with its cystolith. Label all essential structures.

3. Trichomes. Prepare drawings, to illustrate the strueture and relationship to the epidermal layer of various types of hairs. If time permits, also prepare drawings of a scale from the leaf of Shepherdia or Elacagmus, of eolleters as seen in trans-sections of a bud scale, and of the water vesicle of the "Ice-Plant."

4. Describe, by means of diagrammatic drawings, the ontogeny of a water vesicle in the petiole of the "Ice-Plant." Summarize, from information given in Haberlandt, the most important functions performed by the various types of trichomes.

\section{REFERENC'ES}

1. Ajello, L., Crtology and Cellular Interrelationship of Cystolith Formation in Ficus elastica. Amer. Jour. Bot. 28:589594. 1941.

2. Anderson, D. B., The Distribution of Cutin in the Onter Epidermal Wall of Cliviu nobilis. Ohio Jour. Science 34:9-18. 1934.

3. Cooper, D. C., The Development of the Peltate IIairs of Shepherdia canadensis. Amer. Jour. Bot. $19: 423-428.1932$.

4. Crooks, D. MI., Histologieal and Regenerative Studies on the Flax Seedling. Bot. Gaz. 95:209-239. 193:?.

5. De Barr, pp. 29-107.

6. Eames and MacDaniels, pp. 107-112.

7. Foster, A. S., Investigations on the Horphologr and Comparative History of Development of Foliar Organs, I. The foliage leaves and cataphyllary structures in the lorse-chest- 
nut (Aesculus Hippocastamum L.). Amer. Jour. Bot. 16: 441-501. 1929.

8. Haberlandt, pp. 101-133.

9. Hanstein, J., Über die Organe der Harz-und Schleimabsonderung in den Laubknospen. Bot. Zeit. 26: 697-713 et seq. 1868 .

10. Harward, pp. 15-18.

11. Linsbaner, K., Die Epidermis. Iandbuch d. Pflanzenanatomie, IV, 2. 1930.

12. MeVeigh, I., Regeneration in Crassula multicava. Amer. Jour. Bot. 25:7-11. 1938.

19. Naylor, E. E., and Johnson, B., A Histological Study of Vegetative Reproduction in Saintpaulia ionantha. Amer. Jour. Bot. 24:673-678. 1937.

14. Naylor, E., Propagation of Hyacinthus by Leaf Cuttings. Bull. Torr. Bot. Club $67: 602-606.1940$.

15. Netolitzky, F., Die Pflanzenlaare. Handbuch d. Pfhnzenanatomie, IV. 1932.

16. Porterfield, W. MI. Jr.. Histogenesis in the Bamboo with Special Reference to the Epidermis. Bull. Torr. Bot. Club $64: 421-432.1937$.

17. Yarbrough, J. A. History of Leaf Development in Bryophyllum calycimm. Amer. Jour. Bot. $21: 467-484.1934$. 


\section{PARENCIIYMA CELLS}

I. Introduction.-The term "parenchyma" is used in a rather abstract or loose sense to designate a wide variety of living cells which occur in many different regions of the plant body. Parenchyma cells may appear in groups scattered among bighly specialized conducting elements, as for example the cells of vascular rays and the vertical files of phloem and xylem parenchyma cells. Often, however, parenchyma cells form homogeneous or "simple" tissues which may constitute a large part of the softer regions of leaves, stems, roots and fruits. From these illustrations it should be clearly evident that under the concept of "parenchyma" are included cells which differ markedly in their position, origin and functions. For this reason, "parenchyma" is merely a convenient and long-established anatomical category within which are included cell types which are not necessarily either homologous or analogous.

In an effort to characterize parenchyma tissue more precisely. it is commonly described as heing composed of cells essentially isodiametric in form, separated by more or less conspicuous intercellular air spaces, and with thin walls and active protoplasts. To appreciate the merits as well as the limitations of this set of characteristics, the following eritique will be found nseful.

1. Form of cell. The recent work of Marvin (1939) and of Marvin and Matzke (1939) has shown that the form of paren(hyma cells in some regions (e.g., the pith of Eupatorium) is approximately isodiametric and that with respect to the number of faces of contact made with neighboring cells, "the cells show an economy of surface to volume approaching, and in some cases equaling, that of an orthic tetrakaidecahedron or a rhombic dodecalredron of equal volume." This conclusion is particularly interesting in view of Tupper-Carey and Priestley's (1924) statement that the cells of the apical meristem approach the form 
of twelve- or fourteen-sided polyhedra. But, not all cells designated as "parenelyma", are isodiametric in shape. As examples, the following may be eited: the narrowly "cylindrical" for'm of palisade parenchyna cells, the lobed form of "arm-palisade" cells (cf. Meyer, 1923, p. 16) and the elongated shape of the cells in vaseular rays.

2. Structure and chemistry of the wall. During the differentiation of the parenchyma cells in the eortex and pith of stems and in the mesophyll of leaves, little or no appreciable increase in wall thickness occurs and a true secondary wall, clearly defined from the original primary wall, may be absent. In such cells, the thin primary wall seems to consist largely of cellulose. Simple pits are present but they are often restricted to certain loeal regions of the wall (ef. De Bary, p. 117, Fig. 46). In contrast, wood-parenchyma cells and the cells of xylem rays are often provided with relatively thick walls, which are abundantly pitted. Aecording to Eames and MacDaniels (p. 68), the parenchyma cells of secondary wood often have "thick, more or less strongly" lignified walls." Whether the thick areas of the walls of these cells are "seendary" or "primary" in nature apparently eonstitutes an open problem at present.

3. The protoplast. The retention at maturity of an active motoplast represents one of the most important characteristics of parenchyma cells. Indeed, because of this fact. parenchyma cells perform many of the most fundamental physiological processes, notably photosynthesis, food and water storage and secretion (Meyer, 1923; Netolitzky, 1935): Sperlich, 1939). In addition to their important metabolie activity, however, parenchyma cells possess to an exceptional degree the ability to revert to a meristematie state (II irward, 1938, p. 14). This is elearly show hy the rapid response of parenchyna tissue to the physieal and (hemieal effects of artificial or natural wounding. The nature of such responses is highly variable and eomplex, ranging from the production of "allus" or" of eork tissue, to the regressive formation of root or bud primordia [ef. Priestley and Swingle (1929) and Bloch (1941)]. It may be argued that the ease with which parenchyma cells ean be induced to divide and to produce new issues and organ primordia is evidence of their "primitive" or 
"unspecialized" nature. But it is criclent that many factor's, hereditary as well as cnvirommental, influence the process of "regressive differentiation" in parenchyma and that our knowledge of the "potentialities" of such tissue is still in an exploratory stage.

II. Material for the Study of Parenchyma.-At this point suggested material for a preliminary study of storage and photosynthetic parenchyma is described. Additional examples of parenchyma are given in several of the later exercises in this book.

1. Storage parenchyma. As noted above, parenchyma tissue often serves as a region for storage of many different substances, particularly starch. The cotyledons of bean embryos, during the early stages of seed germination, provide useful material. Examine thin sections as well as partially macerated tissue, noting the closely-packed starch grains in the parenchyma cells. Under high magnification, the type and distribution of the simple pits on the various faces of the wall may be clearly studied. Additional examples of storage parenchyma are furnished by the cortical parenchyma of the roung root (e.g., Rumunculus) and the parenchyma tissue of the potato tuber (Solanum tuberosum).

2. Photosynthetic parenchyma. In the subepidermal region of young stems and in the mesophyll of leaves, the thin-walled parenchyma cells contain chloroplasts and perform the function of photosynthesis. Obtain a thin transverse section of the stem of Begonia, and, after mounting it in water, examine the preparation at low magnification. Notice that the cortex (i.e., the region between the epidermis and the cylinder of vascular bundles) and the pith are composed of large, thin-walled "isodiametric" cells. (Note: Several layers of small collenchyma cells are found at the outer edge of the cortex and may be disregarded in this study.) Under low magnification observe that large, solitary prismatic crystals as well as druses occur in many of the parenchyma cells. Frequently, the form of the erystals is highly irregular. Tnder high magnification, the cytoplasm, vacuole and small chloroplasts can be readily studied especially if the sections are mounted in $.1 \%$ solution of neutral red. ${ }^{1}$ Because of the large size of the cells, the nucleus is only seen occasionally in trans-sections of the

\footnotetext{
1 Cf. Appendix, p. 142.
} 
parenchyma tissue. Simall simple pits may be visible in certain walls of the cells. In order to understand the shape and proportions of the parenchyma cells, as well as the intereommunication between the prominent intercellular spaces, longi-sections of the stem should be studied under low and high magnification. Observe that the intercellular space system in the longi-section appears "black" because of the included air. This optical effect is of great assistance in distinguishing between walls and longitudinally extended air spaces.

\section{Suggested Drawings and Notes.-}

1. Prepare an enlarged drawing of a single cell from the cotyledon of the bean seedling, showing its shape, wall structure and the included starch grains. For comparison, draw several cells from the cortex of the root of Ranunculus and the potato tuber. Prepare notes on the differences in the form and structure of the starch grains in these different examples.

2. Prepare drawings, from both transverse and longi-sections, showing the structure of the photosynthetic parenchyma of the cortex of the Begonia stem. Include cells which show erystals, cytoplasm and chloroplasts. What conclusion do you reach as to the shape of the parenchyma cells? Summarize, from the references yon have read, the method of origin and functions of intercellular spaces in parenehyma tissue (cf. especially Turrell. 1936 ).

\section{REFERENCES}

1. Bloch, R., Wound Healing in Migher Plants, Pot. Review $7: 110-146,1941$.

2. De Barr, pp. 115-119.

3. Eames and MaeDaniels, pp. 52-54.

4. Hayward, p. 14.

5. Marvin, J. W., Cell Shape Studies in the Pith of Eupatorium purpureum. Amer. Jour. Bot. $26: 487-504,1939$.

6. Marvin, J. W. and Matzke, E. B., A New Method for the Construction of Three-dimensional Cell Models. Amer. Jonr. Bot. $26: 101-10: 3,1939$.

7. Meser, F. J.. Das trophische Parenehym. A. Assimilationsgewebe. Handbuch d. Pflanzenanatomie. IV. 1923.

8. Netolitzky, F., Das trophisehe Parenchym. C. Speichergrewebe. Handbuch d. Pflanzenanatomie. IV. 1935. 
9. Priestley, J. H., and Swingle, C. F., Vegetative Propagation from the Standpoint of Plant Anatomy. U. S. D. A. Tech. Bulletin No. 151. 1929.

10. Sperlich, A., Das trophische Parenchym. B. Exkretionsgewebe. Handbuch d. Pflanzenanatomie. IV. 1939.

11. Tupper-Carey, R. M., and Priestley, J. H., The Cell Wall in the Radicle of Vicia faba and the Shape of the Meristematic Cells. New Phytol. 2:3:156-159. 1924.

12. Turrell, F. MI., The Area of the Internal Exposed Surface of Dicutrleclon Leaves. Amer. Jour. Bot. 23:25:5-264. 1936.

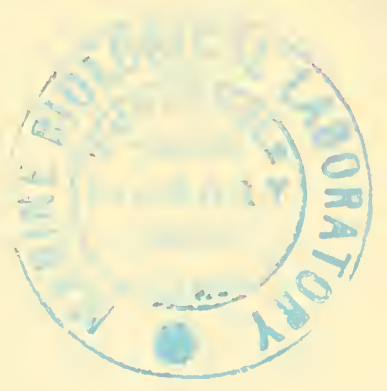




\section{COLLENCIIYMA ('ELLS}

I. Introduction.-The subepidermal region of many stems, petioles and ribs of leaves is occupied by a more or less "simple" or homogeneous tissue which is termed collenchyma. Frequently" this tissue oceurs as a continuous lypodermal cylinder but in some stems and in the petioles of leaves, distinct strands of eollenehyma may be present. An interesting example of the strandlike arrangement of collenehyma is furnished by the familiar "strings" present in the abaxial ribs of celery petioles (cf. Esan, 1936 , pl. 2 and 6 ).

In certain respects, collenchyma is remarkably similar to cortical parenchyma. Indeed Haywart (p. 22) regards collenclyma as a derived form of parenchyma, a riewpoint also expressed by De Bary (pp. 119-120) who stated that "it is then to a great extent a matter of taste how far one will extend the term Collenchyma." The parenehymatous character of collenchyma is shown by the fact that it is a tissue composed of living cells, the protoplasts of which, like parenchyma, are able to revert to a meristematic state. This feature is illustrated by the origin of the phellogen or cork eambim in the ontermost collenchyma cells in many stems. Furtlermore, collenchyma, although primarily a "mechanical tissue" in its function, presumably carries on some photosinthesis as evidenced by the frequent ocenrrenee of chloroplasts in its cells. The shope of collenehyma cells. especially those adjaeent to parenclyma elements in the cortex or petiole, may be more or less "isodiametric." 'Typically, however. collenchyma rells are elongated, prismatic elements with obtuse, pointed or oblique ends.

The most definitive characteristic of eollenchyma cells is found in the irregular and often massive thiclienings of the cell wall. These wall thickenings, which are deposited by the protoplast in the form of extensive longitudinal strips. vary in their 
position according to several definable types of patterns when the cells are exanined in trans-section. In perhaps the commonest type, the thickened areas of the wall are largely restricted to the corner's where the cells meet. Collencliyma of this type is termed "angular." In certain plants, the thickenings are confined to the tangential walls of the cells, resulting in the so-called lamellar collenchyma. Ordinarily, intercellular spaces are small or even absent in collenchyma tissue but in certain Compositae the thickened areas of the walls of the collenchyma cells border upon large and prominent air-spaces. The term "tubular"' has been applied to this type of collenchyma. These "types" of collenchyma, however, are not rigidly distinct, because in some instances transitions from one to the other may occur in successive radial portions of the same zone of collenchyma.

The structure and chemieal composition of the wall-thichenings in collenchyma cells have recently been studied by several investigators. Anderson (1927), in his studies on the angular collenchyma of tomato (Solanum lycopersicum), concluded that the thickenings, which have a high content of water, consist of alternating lamellae of cellulose and pectin. When viewed under crossed Nicols, the walls appeared bi-refringent. Esan (1936) found that the walls of collenchyma cells in celery petioles "are chiefly of cellulose and contain a high percentage of water.' She interprets the wall thickenings as representing a special development of the primary wall. Simple pits are found in the walls of collenchrma cells but are not necessarily restricted to either the thin or thickened areas.

The thorough study of Esan (1936) has shown that the ontogeny of collenchyma tissue in celery petioles exhibits many interesting and important features. In the mature petiole, the collenchyma occurs in the form of distinct strands which correspond in position to the abaxial ribs. The origin of these collenchyma bundles is traceable to the localized periclinal and anticlinal subdivision of ground meristem cells in the young petiole. Procambial-like strands of somewhat elongated, thin walled cells are thereby produced and it is from such cells that the adult collenchyma eventually differentiates. At first the young collen- 
chyma cells are relatively small in diameter but as the rate of cell division slows down, the cells expand and gradually aequire the characteristic angular wall thickenings. The relative prominence of intercellular air spaces in the mature collenchyma strand depends in general upon the time of origin of the tissue. Air spaces are only present when the divisions leading to collenchyma development occur in loosely-arranged ground meristem cells.

Functionally, collenchyma tissue provides considerable strength as well as elasticity to young stems and to leaves. According to Esau (1936), the collenchyma of celery petioles mechanically "is much stronger than the vascular tissue. The breaking load of collenchyma may be two to four times that of the entire vaseular bundles or the bundle eap."

\section{Material for the Study of Collenchyma.-The elearly de-} fined angular collenchyma in the petiole of Datura stramonium provides excellent material and its general structure will now be clescribed. (Note: If Datura is not available, the angular collenchyma in the cortex of the stems of Solanum lycopersicum, Cucurbita, or Begonia, or the collenelyma strands in celery petioles, may be used.)

Obtain a trans-section of the petiole of Datura and after mounting it either in water or a $.1 \%$ solution of neutral red, examine under low magnification. The epidcrm is possesses characteristically thickened outer walls covered by a prominent cuticle; a protoplast and small scattered chloroplasts should be visible in some of the epidermal cells. Note the prominent multicollular umbranched hairs and study carefully the structure of their component cells. Beneath the epidermis are found six or more "layers" of typieal angular collcnch!mma colls, the irregnlarly thickened walls of which exhibit, when viewed in water, a characteristic pearly-white lustre. In sections mounted in dilute neutral red solution, ${ }^{1}$ the walls are brilliantly stained and their relationships more readily investigated. Select a thin well-cut area in the eollenchyma and study the colls under high magnification. The eell eavities have a more or less mululate outline which is the result of the alternation of thin and greatly thickened

1 Cf. Appendix, p. 142. 
areas of the primary wall. These thickened areas will be seen to be restricted largely to the cell-comers, hence the term "angular" collenchyma. Especially in sections stained with neutral red, the wall thickenings exhibit evidence of a lamellated structure. Observe that "spaces," varying greatly in size and distribution, occur throughout the collenchyma tissue. Some of these apparent "spaces" represent the trans-sectional appearance of the narrow tapering ends of collenchyma cells; others are true intercellular air spaces. The distinction between these two conditions is best appreciated, however, by a study of longisections of the tissue. Note the highly vacuolate cytoplasm and the chloroplasts in the collenchyma cells.

To understand thoronghly the shape of collenchyma cells and the distribution of the thickened areas of their primary walls, examine under low and high magnification longi-sections of the Datura petiole. Study carefully the band-like thickenings of the wall and note their relationship in adjacent cells. The intercellular spaces should now be more evident. Simple pits may be seen in both face and section views. Observe that individual cells are often subdivided by thin transverse or sloping walls.

\section{Suggested Drawings and Notes.-}

1. Draw on a large scale a sector of the trans-section of the petiole of Datura (or of the substitute material previously listed) about 5 to 6 cells in width, extending from the epidermis to the cortical parenchyma tissue. Label carefuly all important structures.

2. Prepare a drawing of a small portion of the collenchyma tissue as seen in longi-sectional view. Show clearly the distribution of the thickened areas of the wall, the pitting and the intercellular spaces. Fill in the contents of a single collenchyma cell.

3. Summarize, in the form of laboratory notes, the evidence discussed by Esau (1936) which shows that the walls of collenchyma cells are rich in water.

\section{REFERENCES}

1. Anderson, D., Teber die Struktur der Kollenchymzellwand auf Grund mikrochemischer Untersuchungen. Sitzber. Akad. Wiss. Wien. Math.-Natur. Kl. $136: 429-440.1927$. 
2. De Bary, pp. 119-120.

3. Eames and MacDaniels, pp. it-56.

4. Esau, K.. Ontogeny and Structure of Collenchyma and of Vascular Tissues in Celery Petioles. Hilgardia $10: 431-467$. 1936.

5. Haberlandt, pp. 155-158.

6. Hayward, p. 22. 


\section{Exercise VIII}

\section{SCLEREIDES}

I. Introduction.-From the standpoint of function, two general types of strengthening or "mechanical" tissues are conventionally distinguished, viz.: (1) collenchyma, which is composed of living cells and which is the first strengthening tissue to appear in the development of the stem and leaf, and (2) sclerenchyma which is made up of thick-walled cells, usually lacking a protoplast at maturity and which represents the "permanent" and more important of the supporting tissues in the older portions of the plant body. From a morphological standpoint, many authors (e.g., Eames and MacDaniels, Ilayward) adopt the viewpoint of De Bary (pp. 126-134) and recognize two main "forms" of selerenchyma; namely, "stone cells" which are short, more or less isodiametric elements and fibers which are prosenchymatous rells, often extremely long and with pointed or oblique ends. Despite the convenience of this morphological subdivision of sclerenchyma it seems hardly justified when the numerous structural and ontogenetic differences between so-called stone cells and fibers are clearly understond. For this reason, the term "sclerenchyma" appears vague and highly abstract and, as will appear in the resumé to follow, has been used to designate cell types which are definitely unrelated in wall structure and method of development (ef. IIaberlandt, p. 721, note 92).

The expression "sclereide", was originally proposed by Tschirch (1885, p. 308) for the variously formed thick-walled cells which occur so conmmonly in the bark of woody seed plants, in the hard shell of fruits, and in seed coats. In contrast to typical "bast fibers," the thick walls of selereides often appear yellow in color, are usually highly lignified and possess tubular' pits which may branch in a complex fashion. On the basis of form and structure. Tschireh (1889, pp. 301-302) distinguished four principal types of sclereides which he named and described 
as follows: (1) Brachysclercides, or "stone-cells" which are roughly isodiametric in form and which oceur in the fleshy portion of the fruits of Pyrus and Cydonia and in the bark of numerous woody dieotyledons; (2) Macrosclercides, or "rod-cells" which are colummar in form and often constitute an outer continnous palisade-like layer in the coat of seeds, especially in the family Leguminosae. Iere they are also referred to as "Malpighian Cells"'; (3) Osteoselereides, or "bone-cells" which are likewise columnar in form but possess dilated or knob-like ends. such cells occur within the palisade parenehyma in certain leaves (cf. Haberlandt, p. 160, Fig. 52); and (4) Astrosclereides or "branched sclereides," which are highly irregular in form and size with pointed "arms." Astrosclereides are well developed in the leaves of certain dieotyledons (e.g., Thea, Camellia) and also oceur in the bark of Abies and Larix and in certain fruits (e.g., Carya).

The ontogeny of sclereides presents many distinctive and peculiar features. Aside from the macrosclereides, which are traceable in origin to the surface cells or "protoderm" of the integument of the orule (cf. Zimmerman, 1936), sclereides usually develop by the "secondary sclerosis" of parenehymatous cells (cf. De Bary, pp. 539-544). This curious plocess involves the marked centripetal increase in thickness of the cell wall, the deposition of lignin within the cellulosie matrix and the production of the characteristic "pit-canals" or "ramiform pits." The physiological factors which induce these changes in a living parenchyma cell or cell group in the cortex or the bark of stems or roots are obseure. Tsehirch $(1889$, p. 303$)$ states that in woody dicotyledous, the process of secondary sclerosis oecurs to such an extent that selereides may eventually constitute the major portion of the lark. A further interesting aspect of the process of secondary sclerosis is exhibited by the development in many stems of the so-called "composite eylinder" formed of both mrachyselereides and bast fibers. In this ase, an originally continuous cylinder of hast fibers becomes ruptured at various points as a result of the increase in thickness of the stem. Neighboring parenchyma cells then intrude into the gaps, divide and eventmally become transformed into selereides thus "repairing" 
the broken cylinder (for details ef. T'schirch, 1885, p. 323 et seq., and IIaberlandt, p. 159). With respect to the ontogeny of osteosclereides and astrosclereides, little information appears to exist. In the husk of the fruit of hickory (Carya) a comparison of young and old material clearly suggests that the irregular astrosclereides arise much like brachysclereides from the secondary sclerosis of parenchymatous elements. But the details of the development of the huge astrosclereides occurring in the leaves of such plants as Camellia (Haberlandt, p. 162, Fig. 54) deserve careful investigation.

The statement is frequently made that stone-cells are devoid of a protoplast at maturity. This idea requires further proof because Alexandrov and Djaparidze (1927) contend that it is possible to demonstrate, by staining with safranin and methyl green, the presence of nuclei in the mature brachysclereides of the fruits of quince (Cydonia) and pear (Pyrus). These investigators further maintain that during the ripening of the fruit in Cydonia, the sclereides experience a process of "delignification" consisting in the reduction in thickness of the wall, the disappearance of lignin, and the obliteration of the ramiform pits. This reversible change suggests enzymatic activity on the part of the protoplasm within the stone cells. However, Crist and Batjer (1931) reached a different conclusion in their detailed study of the stone-cells of Pyrus. They state that the delignification reported by Alexandror and Djaparidze for Cydonia does not oceur in Kieffer and Bartlett pears . . "without exception, the downward trend of the cellulose curve is strictly parallel to that of lignin and each one of the two is parallel to the ligno-cellulose trend." Further study is obviously needed to determine more precisely the chemical relations between the selereides and the neighboring parenchyma tissne during fruit ripening.

From a functional standpoint, sclereides undoubtedly impart hardness to the organ in which they oceur. Haberlandt (p. 158) states that brachysclereides "serve to increase the incompressibility of the bark; their action may be compared to that of the sand which a mason nses to increase the tenacity of his mortar, or to that of the powdered glass which is added to gutta-percha in order to render it less compressible." The functional signifi- 
cance of the groups or "nests" of brachysclereides in fleshy fruits is less evident. It has been sugrested that phylogenetically they may represent the remains of a former continuous shell of stone cells.

\section{Material for the Study of Sclereides.-}

1. Brachysclereides or "stone-cells" in the fruit and fruit stalk of Pyrus. Obtain a small fragment of the fruit of pear and mount it in water under a eover glass. Imbedeled in the thinwalled parenchymatous tissue will be found small groups ol "nests" of stone-cells which appear yellowish-brown in color. Examining one of these groups of stone-eells uncler high magnification note the form of the cells, their greatly thickened walls and the characteristic ramiform pits. After this preliminary examination, remove the cover-glass, add several large drops of a saturated solution of phloroglueinol ${ }^{x}$ followed by a drop or two of hydrochloric acid. Note the brilliant red color assmmed by the walls of the sclereides. Often this color change, which occurs when lignin is present in the walls, aids in the study of the branching and the relationship of the ramiform pits. Study carefully the form of the pits in both sectional as well as face view.

Secure a trans-section of the fruit stalk of Pyrus and treat it with phloroglneinol and hydrochloric acid as described above. Add a cover slip and examine the section under both high and low magnification. The edge of the section is formed of several layers of cork the immermost cells of which are in contact with the phellogen or cork eambium. Internal to the phellogen ocenrs the cortex which is composed of thick-walled parenchyma tissue in which are imbedded rests of stone-eflls. Progressing inwards. there next occurs a "ring" of fibrorescular bundles. Each of these bundles eonsists of an external (alp of fibcrs (which are usually less brilliantly stained than the stone-cells of the cortex). a strand of phloem and a strand of $x y l e m$. The pith of the fruit stalk is composed of hoth parenchyma as well as groups of stone cells.

2. Astrosclereides. Obtain a preparation of macelated "husk" of the fruit of c'myg or Juglans and examine it under low mag-

1 Cf. Appendix, 1. 141. 
nifieation. The two most abundant cell types are (1) parenchyma cells which vary from nearly isodiametric elements to irregular for'ms, and (2) astrosclereides which exhibit remarkable variation in the form and proportion of the "arms." The thick stratified wall and branched pits show very clearly in these sclereides. It is instructive to note the frequent similarity between certain of the parenchyma cells and the sclereides, indicating the origin of the latter from parenchyma by the process of seeondary sclerosis which has been described in the Introduction of this exercise.

For comparative purposes, examine trans-sections of the petiole of the leaf of Camcllia after staining then in phloroglucinol and hydrochloric acid. Study the sections under high magnification and note the elaborately branched areas of astrosclereides. Sections through the lamina of the leaf should also be stained and examined for the huge branched sclereides which oceur in the midst of the mesophyll.

3. Macroselereides. Obtained a small amount of macerated bean testa and examine it under low magnification noting the small, tightly packed groups of colummar macrosclereides. Note that the lumen of each macrosclereide is widest near the base of the cell, being reduced to a narrow, virtually occluded channel above. For illustrations of macroselereides in sitn in the testa of seeds of the Leguminosae refer to Eames and MacDaniels (p. 294, Fig. 134c), Hayward (p. 342, Fig. 174), and Netolitzky $(1926$, p. 159).

\section{Suggested Drawings and Notes.}

1. Prepare drawings to show the form and pit relationships of a small group of stone-cells in the fruit of the pear. How may the fact be explained that some of the ramiform pits or their branches fail to terminate at the "edge" of a stone-cell at a given level of focus?

2. Make a diagrammatic drawing of the trans-section of the fruit stalk of the pear, showing and labeling all the important tissues and regions. Summarize, in the form of notes, the positions and mechanical significance of the stone-cells and fibers in this organ. 
3. Draw several types of astrosclereides from the macerated "husk" of the fruit of Carya or Juglans. For comparative purposes, draw a parenchyma cell resembling in its form one of these selereides.

4. Prepare a diagrammatic drawing of the trans-section of the petiole of Camcllia, showing the position of the astrosclereides with reference to other tissues. Draw a single astroselereide, as seen under high magnification, from the petiole and from the lamina of the leaf.

5. Draw a few comnected macrosclereides from the testa of the bean seed. Show carefully the wall structure and the form of the lumen.

\section{REFERENC'ES}

1. Alexandrov, W. G., and Djaparidze, L. I., Über das Entholzen und Verholzen der Zellhaut. Planta $4: 467-475.1927$.

2. Crist, J. W. and Batjer, L. P., The Stone Cells of Pear Fruits, Especially the Kieffer Pear. Ag. Expt. Station Michigan State College. Tech. Bulletin 113. 1931.

3. De Bary, pp. 126-128.

4. Eames and MaeDaniels, pp. 57-59.

5. Haberlandt, pp. 158-161.

6. Hayward, p. 25.

7. Netolitzky, F., Anatomie der Angiospermen Samen. IIandbnch d. Pflanzenanatomie. X. 1926.

8. Tobler, F.. Die mechanisehen Elemente und das mechanische System. Handbuch d. Pflanzenanatomie. IV. 1939.

9. Tsehireh, A., Beiträge zur Kemntniss des mechanischen Gewebesystems der Pflanzen. Jahrb. Wiss. Bot. 16:30:3-3335. 1885.

10. - Angewandte Pflanzenanatomie. Wien und Leipzig. 1889.

11. Zimmermann, K., Zur plysiologischer Anatomie der Leguminosentesta. Jandw. Versuchs-stat. 127:1-56. 1936. 


\section{ExERCISE IX}

\section{FIBERS}

I. Introduction.-In the strict sense, the term "fiber" should be applied only to certain prosenchymatous cells found in the inner tissues or tissue systems of the plant body. Cells of this type are not to be confused with the so-ealled cotton "fibers" which morphologically represent epidermal hairs of the seed coat (ef. Anderson and Kerr, 1938). The term "fiber" is employed in the present book in the above restricted anatomical sense.

Fibers are the most important type of mechanical cell which oceur in higher plants where their great tensile strength, flexibility and elasticity serve to enable plant organs suecessfully to withstand a variety of strains and tensions resulting from the action of gravity, wind, ete. (Cf. Haberlandt, pp. 161-164.) From a commercial standpoint, many plants are cultivated largely or exclusively for the fibers which they produce. Among the more prominent of such textile plants may be mentioned Agave sp., the source of "Sisal Hemp," Musa textilis from which "Manila Hemp" is derived, Cannabis sativa or the "trne" hemp plant. and Linum usitatissimum, which furnishes the commercial flax from which linen is derived. Aceording to Hayward (p. 371), "there is evidence that flax was grown during the Stone Age" and that the annual form of Limum usitatissimum "has been grown in Mesopotamia for at least 4000 years.'

Becanse of the considerable economic importance of fibers, a very extensive literature has developed. The limited scope of this book however precludes any effort to disenss in detail the many involved problems of wall structure and methods of development of fibers. Instead, a brief resumé is given now of the salient features of fibers which may serve as an introduction to 
the subject. For students wishing additional technical information, reference should be made to the literature cited by Hayward under Cannabis (pp. 244-245) and Limum (pp. 409-410).

1. Classification. Fibers, either singly or more commonly in the form of strands or eylinders, are widely distributed in the plant body. In stems and roots, fibers are commonly found in the cortex, pericyele, phloem and xylem. In the leaves of many monocotyledons (e.g., Musa, palms, Agave, ete.), fibers are very prominently developed, occuring as strands or sheaths which acempany the vascular bundles; they may also appear independently of the raseular strands, either as distinct bundles or as massive hypodermal eylinders. (Cf. Haberlandt, pp. 168-184, and Meeuse, 1938.) From a topographical standpoint, two principal "types" of fibers may be recognized, at least in stems and roots which experience secondary growth in thickness, viz.: (1) Bast or extracambial fibers, and (2) Wood fibers or intracambial fibers. As Ilaberlandt (p. 15i) has clearly emphasized, such a distinction is quite arbitrary since hast fibers, as a class, camot be distinguished on a structural basis from wood fibers. Eames and MacDaniels (p.57) and IIayward (p. 23) suggest that fiber types should be more specifically designated according to the tissue or tissue region in which they oceur, e.g., cortical fibers, perieyelic fibers, phloem fibers, ete. A classification of this kind, howerer, necessarily depends upon acenrate information on the origin and development of the fibers in each particular case. This is very clearly shown by the recent investigations of Esan (1938b, pp. 367-369) on the origin and development of the fibers in the stem of tobacco. In this plant, Esan interprets the fibers morphologieally as part of the primary phloem rather than as "pericyclie fibers," as has been done by eertain workers. It is evident from Esau's discussion of the literature that there is a great need for a complete re-examination of the concept of "pericycle" from an histogenetic point of view. Inder sueh ciremustances, the classifications of fibers into "bast fiber's" and "wood fibers" will be followed in this book laregely for the sake of simplieity and convenience.

2. Form and length of fibers. Fibers are classical examples of typieal prosenchymatous cells. The euds are either acute or 
acuminate or, as in certain bast fibers, variously "lobed" or "branched" (Mansfield, p. 20, Fig. 2). In short fiber's, the ratio of the diameter of the cell to its length may average $1: 10$ to $1: 20$ while in extreme cases (e.g., in the Urticaceae) the ratio may reach or exceed $1: 4000$. These data, taken from De Bary (p. 13), emphasize the fact that certain bast fibers may represent the largest of all cells in ligher plants. According to Hayward's (p. 241) discussion of the literature, hemp (Cannabis sativa) fibers vary in length from 1-10 ('m. In flax (Limum) the length of the fibers likewise varies from $2.5 \mathrm{~cm}$. to as high as $12 \mathrm{~cm}$. Apparently the longest bast fibers which have been accurately measmed occur in the stem of Bochmeria nivea, a member of the Urticaceae. In this species, Aldaba (1927) succeeded, by means of a special maceration technique, in isolating individual fibers, the five longest of which measured "respectively 400, 500, 520,540 , and $550 \mathrm{~mm}$.',

3. Structure and ehemistry of the coll wall. Nature fibers characteristically possess a well-defined secondary wall which is often so thick that the cell humen may be almost or entirely occhnded at varions points. The thick secondary wall exhibits typically slit-like vestigial pits which in bast fiber's are disposed obliquely in a left-handed spiral series. Haberlandt (p. 154) contends that this arrangement of pits indicates a "corresponding arrangement of the micellar rows" and that "an obliquely pitted bast-fiber may therefore be regarded as an aggregate of exceedingly numerons and delicate fibrillae twisted together into a spiral coil of many turns which surrounds a longitudinal canal consisting of the cell cavity." Becanse of the great economic importance of certain fibers, many stuclies have been devoted to the chemical composition of their walls. Hayward (p. 23), while admitting that the degree of lignification of the cell wall may vary even within the same zone of fibers, distinguishes between (1) nonsclerotic fibers, which occur commonly in the pericycle of stems and which possess secondary walls with a relatively high proportion of cellulose (e.g.. Linum), and (2) selerenchymatous fibers, which are part of the xylen and which exhibit highly lignified secondary walls. According to IIayward, lignification tends to render fibers rather brittle while the high cellulose content of 
the walls of certain bast fiber's is related to the greater tensile strength and durability of such elements.

4. Ontogeny of fibers. Regardless of their location in the plant, fibers arise from initial cells which are very short as compared with the length of the mature element. An impressive example of this fact is furmished by Aldaba's (1927) work on fiber development in Bochmeria. In this plant, the fiber' initials "are approximately 20 microns in length" and "the increase in the longitudinal dimension of the longer bast fibers is of the order" of 2.500,000 per cent, but the process of elongation is gradual and extends over a number of months." The mechanics of the process of elongation in fibers and the accompanying development of a thick seeondary wall has attracted much attention as well as speculation. The investigations of Aldaba (1927) and Anderson (1927) on flax fibers have revealed many peeuliarities but our knowledge of fiber development in other forms is still meagre. It is apparent that in certain bast fibers. the upper end of the element remains delicate and aetive during the phase of cell elongation. Whether the necessary adjustment between such greatly extending cells and their neighbors is achieved by "sliding", growth or by "differential" growtl, however, is not clear. (Cf. Anderson 1927, Meense 1938 and Harward 1938, pp. 395-400.) The behavior of the protoplast during the growth and differentiation of certain types of fibers offer's a number of points of interest. In a recent study, Esau (1938a) has shown that during the elongation of the primary phloem fibers in tobaceo. the protoplasts become multimuleate as a result of repeated mitotic divisions of the nuelei. ('ell plates, however, do not form at the end of the snceessive unclear divisions and "the spindle fibers are less persistent than in ordinary division figmres." At the final stages in fiber ontogeny, usually after secondlary walls have developed, the muclei appear to fuse or clump and in nearly" mature fibers "the muclear material frequently necurs as one large degenerating mass." The physiologieal signifieance of this multinucleate condition in young phloem fibers is quite obsenre. IIaberlandt (p. 15t) who has observed a multinueleate protoplast in the bast fibers of linum and eertain members of the Leguminosae maintains that "the presence of several nuelei appears 
advantageous when the rery considerable length of many bast-cells and their active growth in length and thickness are taken into account." In certain types of wood fibers, however, mitosis is followed by eytokinesis, resulting in a chambered or septute fiber. This condition has been observed and described by Vestal and Vestal (1940) in a recent study of the septate fiber-tracheids of Hypericum Androsacmum. In this species, the fiber-tracheid retains its protoplast after the thick secondary wall has been laid down. Mitosis may then oceur in snch a cell, the division figure being oriented parallel to the long axis of the cell. Cell plate formation then occurs in the normal manner and a thin transverse septum is formed across the lumen, intersecting the inner edge of the secondary wall of the "mother cell." Because of the delicacy of this septum it was not possible to determine whether it is "formed only of intercellular cement substance or whether it consists of the inter'collular substance and two adjacent primary walls."

\section{Material for the Study of Fibers.-}

1. Bust fibers. Examine, moler low and high magnification, macerated bark of the twig of the basswood or linden tree (Tilin sp.). The numerous prosenchymatous cells present are bast fibers from the phloem region. Select an unbroken fiber and study carefully its form and wall structure. Note especially the channel-like lumen and the small vestigial pits. According to Eames and MacDaniels (p. 57), the pits in bast fibers represent modified simple pits. To appreciate fully the arrangement and mechanical significance of the fibers in the phloem of Tilia, strip) off a small portion of the bark from a twig or young branch and scrape off the onter tissues (i.e. epidermis, periderm and cortex) with a scalpel. Then monnt the fibrous tissue which has been exposed in water and examine it under low magnification, noting the closely-joined strands of gravish-white bast fibers. In order to determine the degree of lignification of the secondary walls, treat separate portions of the fibrous network with (1) IKI and sulphuric acid, ${ }^{1}$ and (2) phlorogheinol and hydrochloric acid. ${ }^{2}$

1 Cf. Appendix, p. 141.

2 Cf. Appendix, p. 141. 
If time permits, make similar studies and microchemical tests of the bast fibers of various economically important textile plants, such as "hemp" (Agave sp. and Cannabis sativa) and flax (Linum usitatissimum).

2. Wood fibers.

(a) Libriform fibers. The fibers present in the seeondary xylem of woody chicotyledons often show massively thickened secondary walls provided with seattered and rather small restigial pits. In such cells, which were termed "libriform" because of their struetural resemblance to phloem fiber's, the lumen raries in width and may be entirely ocelnded at certain points (cf. Eames and MacDaniels, p. 63, Fig. 34, e, f, g). Study the form and structure of the libriform fibers as shown in macerated wood? of oak (Quereus sp.).

(b) Scptate fibers. This type of wood fiber is eharacterized by the subdirision of the lumen into a series of compartments which are separated from each other by transverse walls or septa. The work of Vestal and Vestal (1940) diseussed in the Introduction of this exereise has shown that in Hyperieum, the septa of the fiber-traeheids arise, after the formation of the lateral seeondary wall, as a result of repeated mitoses accompanied by eytokinesis. Doubtless the septate fibers in other genera of the angiosperms pursue a similar ontogeny. Secure a small amount of macerated xylem from the stem of the grape-vine (Titis sp.) and study moler high magnification the form and structure of the numerous septate fibers. Note that the septa in these eells extend to the inner edge of the secondary wall but are independent of the compound middle lamella of the "mother" cell." If the septa are examined with the aid of an oil-immersion lens, it is apparent that they have a laminated as well as a "pitted" structure.

\section{Suggested Drawings and Notes.-}

1. Prepare "areful drawings to illustrate the form, character of the lumen and the type and distribution of pits in the bast fiber of T'ilia and the libriform fiber of Quereus. Label all important structures.

2. Prepare a diagram to illustrate the arrangement of the strands of bast fibers in the stem of Tilia. 
3. Draw a single septate fiber from the secondary xylem of Vitis showing its form, pitting and the position and structure of the septa.

4. Prepare a brief resumé of the commercial process of "retting" fibers in hemp or flax (for literature and information ef. Hayward, pp. 242, 244-245 and 409-410, and Anderson, 1927).

\section{REFERENCES}

1. Aldaba, V. C., The Structure and Development of the Cell Wall in Plants, I. Bast fibers of Boehmeria and Linum. Amer. Jour. Bot. $14: 16-24.1927$.

2. Anderson, D. B., A Microchemical Study of the Structure and Development of Flax Fiber's. Amer. Jour. Bot. 14:187211. 1927.

3. - - - and Kerr, T., Growth and Structure of Cotton Fiber. Indus. and Eng. Chemistry $30: 48-54.1938$.

4. De Bary, pp. 128-134.

5. Eames and MacDaniels, pp. 56-57, 62-64 and p. 75 .

6. Esau, K., The Multinucleate Condition in Fibers of Tobacco. Hilgardia $11: 427-434$. 1938a.

7. - - Ontogeny and Structure of the Phloem of Tobacco. Ibid., $11: 343-424$. 1938b.

8. Haberlandt, pp. 152-155.

9. Ilayward, pp. 23-25.

10. Mansfield, pp. 89-106.

11. Meeuse, A. D. J., Development and Growth of the Sclerenchyma Fibers and Some Remarks on the Development of the Tracheids in Some Monocotyledons. Rec. trav. bot. neerlandais $35: 288-321.1938$.

12. Vestal, P. A. and Vestal, M. R., The Formation of Septa in the Fiber-tracheids of Hypericum Androsuemum L. Harvard Bot. Mus. Leaflets $8: 169-180.1940$. 


\section{Exercise $\mathrm{I}$}

\section{TRACHEARY ELEMENTS}

I. Introduction.-One of the most characteristic features of the sporophyte of the "Tracheophyta" is the presence of a welldefined conductive or vascular system. This system is histologically complex in that its two component "tissues," i.e., phlocm and rylem, are formed of a variety of cell types differing in their arrangement, form, protoplasts and wall structure. While the functions of storage and mechanical support are performed to varying degrees by both the phloem and the xylem, these "complex tissues" are concerned first of all in the trans-location of water and solutes between root and shoot. This conductive function is possible not ouly because of the structural characteristics of the cells themselves but also because the rascular tissues in the root, stem and leaves are interconnected and form a continuous system. From this standpoint, the vascular system may be visualized as an internal "skeletal" framework to which new increments are added during growth by the activity of the apical meristems and, in plants with secondary growth, the vascular cambium. This exercise is deroted to an introductory study of the xylem, with particular emplasis upon the structure and development of its definitive tracheary elements, viz. : the tracheid and the resscl. In the exercise dealing with the anatomy of the root, stem and leaf, additional information regarding xylem and directions for studying it will be given.

1. Structure and morphology of tracheary elements. The expression "tracheary elements" is used in this book to designate collectively the tracheid and the vessel element which represent the two chief types of water-conducting eells present in the xylem of vascular plants. The following characteristies are commion to both traclieids and ressel elements, viz: (1) they are trpically mosenchymatous in form with oblique or pointed ends. An exception to this is furnished by the cylindrical form of ressel 
elements in certain angiosperms. (2) The secondary wall of mature tracheary elements consists of lignified cellulose and is deposited as rings, spiral bands, bars, a reticulum or as pitted layers upon the thin primary wall; (3) at maturity, tracheary elements lack a protoplast and the lumen is oceupied by gas or fluids. The principal distinction between the two types of tracheary elements consists in the fact that the tracheid is an imperforate cell with a continuous primary wall, while a vessel element is provided with distinct openings or perforations which are usually located in the end-walls of the cell. When longisections of the xylem are examined, it is evident that intercommunication between adjacent tracheids is possible by means of the bordered pit-pairs on their lateral walls. In contrast, vessel elements occur in more or less distinct vertical series in which the perforations of adjacent elements exactly coincide. Thus, collectively regarded, a series of vessel elements constitutes an open "pipe-like" structure which is termed a vessel. The literature devoted to the structure and pitting of tracheary elements is so extensive that it will only be possible to outline below some of the most salient features of tracheids and ressel elements.

(a) The tracheid. From a phylogenetic standpoint, the tracheid is usually regarded as the "fundamental" cell type in the xylem of rascular plants. According to Eames and MacDaniels (p. 62), "tracheids alone probably made up the xylem of very ancient plants." Among living plants, tracheids constitute the only type of tracheary element in the xylem of most lower vascular plants and, except for the Gnetales, are the dominant cell type in the rood of grmnosperms. Tracheids are also characteristic of angiospermous xylem where together with ressel elements, fibers and parenchyma they contribute to produce the great histological complexity typical of the wood in this group. Structurally, the tracheid is an elongate cell, the secondary wall of which is laid down in a variety of patterns. In primary xylem, i.e., the xylem which develops first in the ontogeny of the root, stem and leaf, the secondary wall has the form of rings, spiral bands, bars, a network or else is provided with dis.. tinct pits. A more detailed discussion of the "fibrous" types of secondary wall-thickening in the tracheary elements of primary 
xylem will be given later in this Introduction. In secondary rylem, i.e., the wood produced by the vaseular eambium, the walls of the tracheid are provided either with transverse, slit-like scalariform bordercel pits (as in fer'ss, and club mosses) or with circular or orel bordered pits (as in most gymnosperms and angiosperms). The type and arrangement of the pits of tracheids seem to be determined in part by the nature of the cell or cells bordering the tracheid. Thus when two tracheids are in contact, bordered pit-pairs occur while, if a wood-parenchyma or woodray cell crosses the tracheid, half-bordered pit-pairs are developed. Frost (1929) in a study of angiosperm xylem, however, has called attention to the fact that the type of pitting in a given tracheary element depends to a large extent upon the degree of phylogenetic specialization of the cell itself rather than upon the type of neighboring cells. Frost finds that the pit-pairs between tracheary elements and parenchyma cells may be either bordered, halfbordered, or simple, according to the species and that this situation constitutes a reliable criterion for distinguishing the xylem of various plants. It seems clear that the whole question of tracheary pitting demands more study both from a comparative as well as an ontogenetic point of view. Incleed, considerable diversity of opinion prevails as to the nature of the most primitive type of pitting in seed-plants (cf. Jeffrey Ch. IV and VII, Brown 1918 and Bliss 1921).

(b) The vessel clement. This type of tracheary element is generally interpreted as having evolved, phylogenetically, from some primitive type of tracheid. In the genus Ephedra for example, the sloping end walls of certain of the tracheary elements are provided with rirenlar bordered pits, the membranes of some of which disappeas during ontogeny. Cells of this type may typify one of the ways in whicls the perforotions, distinctive of ressel clements, may have orginated (of. Jeffrey, pp. 94-95, Figs. 72 73). Further evidence of the derived nature of vessel elements is afforded hy their distribution in extinct and living vascular plants. Aecorrling to Jeffrey (p. 93), vessels are absent from the seenulary wood of Paleozoic cryptogams. Among existing lower vascular plants, ressels are known to occur in certain species of Sclaginclla (Duerden 1934) and in two species of Pteridium 
(Bliss 1939). Save for these examples, and the Gnetales, vessel elements seem to be restricted in their occurrence to the xylem of angiosperms. The recent survey of Cheadle (1939) has brought out the interesting fact that while vessels occur consistently in the roots of monocotyledons, this type of tracheary element is comparatively infrequent in the xylem of the stems and leaves of this class of the angiosperms. The significance of this condition remains to be explained. In the dicotyledons, vessels apparently are of widespread occurrence in both primary and secondary xylem, and have only been reported absent in Drimys, Trochodendron, Tetracentron (cf. Bailey and Thompson 1918) and certain members of the Crassulaceae and Cactaceae.

Two principal types of perforations occur in vessel elements. viz.: (1) the simple perforation, which appears as a single large oval or circular hole in each of the end-walls of the cell, and which is interpreted as the more advanced condition, and (2) the scaluriform perforation or perhaps more accurately the sculariform perforation platc, which appears as a series of elongated parallel openings separated by transverse bars, and which is usually regarded as the more primitive type of perforation. Simple perforations occur in vessel elements with either sloping or transverse end-ralls while scalariform perforations are typical of elements with oblique or strongly-inclined end-walls (cf. Eames and MacDaniels p. 65, Fig. 35). According to the inrestigations of Cheadle (1939), in the majority of monocotyledons examined the vessel elements possess the scalariform type of perforation plate. A full discussion of the possible evolutionary history of the perforation-plate in vessel elements of the seed plants is given by Jeffrey (pp. 92-102) and Bliss (1921).

2. Ontogcny of trachcary elements.

(a) The formation of perforations in resscl elements. Recent studies of this problem have centered about two important (questions, viz.: (1) the exact period or time in ressel differentiation when the dissolution of the end-walls occurs, and (2) the physical and chemical nature of the portion of the end-wall which becomes perforated. According to Eames and MacDaniels (p. 151), the perforation of the transverse end-walls of the vessel elements in the secondary xylem of the black locust (Robinia 
Pseudo-Acacia) oceurs after the cells have reached their full size and have leveloped secondary walls over all portions of the element. Perforation in this species therefore involves the dissolution of a portion of both the seeondary as well as the primary layers from the central region of the end-walls. Esan (1936). however, in her study of ressel development in the primary xylem of celery, found that the seeondary thickening. in the form of spiral bands, is restrieted to the lateral walls and to a thin peripheral region of the transverse end-walls. The perforation in this case involves the breakdown of a distinct eentral region of the end wall which is interpreted as primary in nature. This area in seetion view appears as a lenticnlar thickening and is "similar" to the torus thickening in bordered pits." In a later publication. Esau and Hewitt (1940) investigated the nature of the end-walls and the development of perforations in the ressel elements of Cucurbita pepo, Zea mays. Yieotiana tabacum. Daneus earota and Beta vulgaris. The end-walls of Betu. Dancus and Nicotiana. agree with those in eelery in possessing a conspienous lens-shaped thickening which breaks down to form the simple perforation during the final stages of vessel development, after seeondary walls have been formed. Perforation of the vessel elements in Cueubita oecurs at a similar period in ontogeny but in this form the portion of the end-wall to be dissolved is not lens-shaped in sectional view. As a result of careful mierochemical and optical tests of the end-walls, Esau and Hewitt conclude that "two superimposed ressel elements are separated from each other by two collulose layer's-the two prinary walls-cemented together by isotropic intereellular substance."

(b) The neture and origin of "fibrous" thiclenings in primary rylem tracheae. The secondary wall of the tracheary elements in primary xylem is deposited upon the delieate primary wall in a number of well-defined patterns. In the protoxylem or first-formed portion of the primary xylem. the secondary wall appears in the form of separate rings (ammular clements), one or more spiral bands (spiral olomonts) or as transverse, intereonnected hars (sculuriform clemonts). These distinctive trpes of tracheary elements usually originate suecessively in provascular tissue ("procambium") in the order named above, although the 
proportion of each type varies within wide limits in different organs and different plants. The assmmption is frequently made that the significance of these various wall-patterns in protoxylem tracheae is to permit the elements to "accommotate themselves" to stretching. In the metarylcm or last-formed portion of the primary $x y l e m$, there is a marked increase in the relative extent of secondary wall deposition, and elements with net-like thickenings (reticulate elements) and with pitted walls (pitted clements) are formed. A sharp transition does not exist, however, between these varied wall-patterns and consequently the limits between protoxylem and metaxylem can only be rather arbitrarily established. Indeed, it is common to find tracheary elcments with several types of intergrading wall-patterns. Such transitional types were early recognized and termed "vasa mixta." (Cf. De Bary, p. 156.)

Apparently very little intensive study has been devoted to the origin and mode of development of the fibrons type of secondary wall thickening in primary xylem tracheae. Stover (1924) contends that in Calamovilfa "the anmular and spiral thickenings are the direct result of elongation." He finds that the "first thickening is laid down in the pitted form" and that "the division and enlargement of the surrounding cells tears apart this wall thickening and the cell becomes annular, spiral or reticulate, depending upon the amount of stretching." This interesting mechanical interpretation, however, could not be confirmed by the work of Barkley (1927) on the differentiation of tracheary elements in Trichosanthes. According to Barkley, the future pattern of the secondary wall is determined early in ontogeny by a peculiar distribution of vacuoles in the peripheral cytoplasm of the procambial initial. She states that "the spiral ressel of the protoxylem in its early stages has bands of peripheral cytoplasm which precede the spiral markings and have the same arrangement, and become the basis of the lignified spiral. The position of the cytoplasmic bands is determined by rows of vacuoles in the cytoplasm immediately preceding and during the formation of the cytoplasmic bands." In a similar way, the annular and reticulate types of thickenings are predetermined by the pattern of vacuolation in the cytoplasm. It is evident, however, that a 
careful cytological study of this problem from an extensive as well as an intensive standpoint is needed in advance of any generalizations. With the aid of recent improvements in plant microtechnique, it should be possible to investigate successfully the precise relationships between the cytoplasm and the development of specific wall-patterns in tracheary elements.

3. The distinction betuecu primary and secondary vascular tissues. In practice, great difficulty is experienced in attempting to distinguish the boundaries between the primary and seeondary vaseular tissues especially in leaves and young stems. Protoxylem, because of the definitive characters of the secondary wall patterns, is usually readily demareated but the linits between metaphloem and seeondary phlnem on the one hand, and metaxylem and secondary xylem on the other hand, are often diffieult or indeed impossible to draw on the basis of adult structure. One of the criteria often employed is based on the idea that the conducting elements of secondary vascular tissues, since they originate from periclinal derivatives of the cambium, are arranged in more or less regular radial rows in contrast to their irregular arrangement in primary phloem and primary xylem. In a recent review of this whole problem, Esan (1938, pp. 356-361) has shown. however, that according to many ontogenetic studies, the firstformed or "primary" vaseular tissues "may be arranged in an orderly manner." $\Lambda$ good illustration is furnished by the radial alignment of both "primary" and "secondary" tracheary elements in the vasenlar bundle of Trifolium (Eames and MaeDaniels, p. 25.5, Fig. 117 A). Evidently then, the method of arrangement of tracheary cells does not provide a eonsistent basis for demareating primary and secondary xylem. IIowever, when ecrtain differences are andysed between the so-called procambium, which produces the primary vasenlar tissue and the "cambium" whieh forms secondary vasenlar tissues, it appears that the distinetion between the two tissues may have some justification ontogenetically.

Aeeording to Esan. four significant differences can be recognized, viz: (1) in oroans with well-defined secondary growth, two kinds of initials, the ro!y and fusiform types, are characteristic of the cambium. These initials produce respectively the 
vascular rạs, and the sieve-tubes, vertical parenchyma, fibers and tracheary elements. Usually procambial cells are very much alike in form and structure. (2) As seen in trans-section, procambial cells tend to be polygonal in form in contrast to the rectangular or "box-like" shape of cambial cells. (3) The maturation, especially of tracheary elements, from the cambium is more abrupt than is the case in the procambium, and (4) the radial walls of cambial cells are often noticeably thicker than the tangential walls, a distinction which is not apparently characteristic of procambial cells. In view of the above differences and because of the exploratory state of the problem, the terms "primary" and "secondary" will be utilized in this book as convenient designations for the vascular tissues derived respectively from the procambium and the cambium. But the author is in full agreement with Esan's statement that procambium and cambium are to be regarded "not as two distinct meristems, but as two developmental stages of the vascular meristem.",

\section{Material for the Study of Tracheary Elements in Pri- mary Xylem.-}

1. Transverse and longi-sections of the hypocotyl of bean seedlings. Treat the sections with phloroglucinol and hydrochloric acid, ${ }^{1}$ mount in water and examine under low and high magnification. Note carefully the irregular arrangement of the tracheary elements in the differentiating primary xylem as shown in the trans-sections. The longi-sections, if cut in the radial plane with respect to the primary xylem, will show the order of appearance and the types of secondary wall-patterns in the tracheary elements of the protoxylem and metaxylem.

2. Prepared and staincd transverse and longi-sections of the stem of Trifolium. Examine the trans-sections noting particularly the regular arrangement of the tracheary elements in the primary xylem of the collateral vascular bundles. A study of the longi-sections will reveal not only the various types of wallpatterns in the successive tracheary elements, but will also show the effects of stretching on the primary and secondary walls of the annular and spiral elements of the protoxylem.

\footnotetext{
1 Cf. Appendix, p. 141.
} 
3. Hacerated primary xylem of the hypocotyl of bean and the stem of Trifolium. Obtain small quantities of the macerated tissue and study the form and wall-patterms of the varions types of isolated tracheary elements. Although many of the elements may be broken or injured in the process of maceration, it is possible to find intact tracheids or vessel elements. Note especially the intergradations in certain elements between several different types of secondary wall thickening. It is also instructive to eontrast the appearance of the rings and spiral bands in short and elongated protoxylem elements.

4. Macerated primary xylem of the rhizome of the bractien. forn (Ptcridium latiusculum). Obtain a' small amount of macerated primary xylem of Pteridium, mount it in water and add a eover-glass. The individual tracheary elements are large cells, clearly visible to the naked eye, and rary in form from broadlyfusiform or obovate to narrowly-acminate. Examine these cells under low and high magnification, noting that one or both endwalls are oblique with referenee to the lateral walls. The latter are provided with vertical series of typical scalaviform bordered pits. The presence of well-defined scalariform perforation plates on the sloping end-walls of certain of these eells indieates that they represent ressel elements. Aceording to the recent work of Bliss (1939, p. 620) "there are many cells that may be interpreted as transitional between the traeheid and the ressel element."

\section{Material for the Study of Tracheary Elements in Sec- ondary Xylem.-}

1. Tracheids of y!jmnosperms. Obtain a small quantity of macerated wood of Pinus and study the form and pitting of the tracheids. 'Three types of clements are present, viz.: (1) tracheids from the "spring wood," characterized by their relatively wide lumina and by the restriction of pits to the radial walls; ("2) trachejds from the "summer wood," distmonished by their much narrower lumina and by having the pits eonfined to the tangential walls, and (3) fiber-tracheirls which in their thickened walls and reduced pits are intermediate in charaeter between "typical" fibers and tracheids. Note, especially in the spring tracheids, that at certain points in the cell there oceur groups of large, in- 
distinctly borklered pits which mark the point of contact between the tracheid and the living cells of a wood-ray. As seen in face view, the large circular bordered pits of a spring tracheid are separated from one another by bar's of wall substance (cf. Eames and MacDaniels, p. 29, Fig. 17 A). These wall-sculpterings are termed "Bars of Sanio" and have oceasioned much speculation as to their significance. The Committee on Nomenclature of the International Association of Wood Anatomists, however, suggests that the term "Bairs of Sanio" should be replaced by the term "crassulae" which are defined as "thicker portions of the intercellular layer and primary walls between primary pit fields." To appreciate fully tle form and distribution of pits in conifer tracheids, a study should also be made of stained transverse, radial and tangential sections of pine wood.

2. Tracheids of angiosperms. Mount a small quantity of macerated oak wood in water and study carefully the form and pitting of the traclieids. These cells are distinguished from the very abundant wood fibers by their somewliat shorter length, wider lumina and more ohviously bordered pits. Many of the tracheids will appear very irregular in contour with forked or lohed ends. (Cf. Eames and MacDaniels, p. 60, Fig. 33D). Under high magnification, note that the bordered pits are oval in form, often crowded and somewhat smaller than the larger circular bordered pits characteristic of the spring tracheids of Pinus.

3. Tessel elements with sealariform perforations. Macerated wood of birch (Betula) and of the tulip-tree (Liriodendron) will provicle instructive examples of this primitive type of ressel element. Note the rariation in the number and relative width of the slit-like openings in the oblique perforation plates of these two plants, and the variety in type and arrangement of pits on the lateral walls.

4. Tessel elements with simple perforations. As stated in the Introduction of this exercise, the simple type of perforation may occur in vessel elements with either oblique or more or less transverse end-walls. The first condition is shown by certain of the ressel elements in macerated oak wood. Note in this material that the pointed ends of the vessel element extend beyond each of the 
large, oval terminal perforations. $\Lambda \mathrm{s}$ in the ressel elements of Betula and Liviodendron, various types and patterns of pits are characteristic of the lateral walls. A study of the short cylindrical type of ressel element, with greatly-enlarged simple perforations in the transverse end-walls, may be made with the aid of stemsections and macerated xylem of the pumpkin (Cucurbita). As seen in macerated tissue. the indiridual ressel elements are somewhat drum-slaped witl densely-pitted lateral walls. The enolmous diameter of these ressel elements and their union to produce ressels may readily be studied in hand-sections stained with phloroglueinol and hydroehlorie acid. For a description and illustrations of the development and structure of vessels in Cucurbita reference should be made to the work of Esan and Hewitt (1940).

5. The cellular composition of paper. A large proportion of paper is obtained from the wood of certain grmmosperms (e.g.. Abies, Piceu) and angiosperms (e.g., Populus, Betulu). The first stage in the manufacture of paper from wood consists in the meehanical and elemical maeeration of the xylem which results in the partial dissoeiation of its component cells. This macerated xylem is eommereially known as wood pulp and after" being bleached, colored or "sized," aceording to the required use, is compressed under great pressure into paper sheets (ef. Kellog. 1923 for further details). It is interesting to note, however. that despite the drastic treatments involved in the production of wood pulp, many of the tracheary elements are well preserved and thein structure and pitting is recognizable if small pieces of soaked paper are carefully teased apart in water and examined under the microseope. Make a study of the varions types of eells found in newspaper, blotting-paper and some eheap grade of writing-paper.

\section{Suggested Drawings and Notes.-}

1. Prepare drawings to show the slape, structure, and arrangenent of the primary xylem tracheae in the vasenlar bundle of the bean hypocotyl or the stem of Trifolium, as seen in transand longi-sectional view. These drawings should be supplemented by showing, on a lange scale, the details of small portions of the secondary wall-patterns of isolated clements of the proto- 
xylem and metaxylem drawn from macerated primary xylem of the hypocotyl of the bean seedling.

2. Outline, on a large scale, the form of a single vessel element from the macerated primary xylem of Pteridium, indicating by horizontal lines the pattern of scalariform bordered pits on the lateral walls. Draw, as seen under high magnification, a scalariform perforation plate of one of these tracheary elements.

3. Prepare drawings of spling and summer tracheids of macerated pine wood, showing the type and arrangement of the pits as seen in face and sectional view. For comparison, draw a single tracheid from macerated oak wood.

4. Make drawings of ressel elements of macerated wood of Liriodendron (or Bctula), Quereus and Cucurbita, to illustrate differences in the form of the elements and the type of perforation. Fill in the pits on a small portion of the lateral wall of each ressel element.

5. Summarize, in tabular form, the various types of cells observed in the specimens of paper studied. Indicate whether differences in the kinds of tracheary elements observed ean be used to deduce the source of the paper in each case, i.e., from conifer or angiosperm wood.

6. Prepare a resumé, based upon the conclusions of Jeffrey, Brown (1918) and Bliss (1921) of the evolutionary development of the vessel in seed plants.

\section{REFERENCES}

1. Bailey, I. W., and Thompson, W. P., Additional Notes upon the Angiosperms, Tetracentron, Trochodendron and Drimys in which Vessels Are Absent from the Wood. Amm. Bot. $32: 503-512.1918$.

2. Barkley, G., Differentiation of Vascular Bundle of Trichosanthes anguina. Bot. Gaz. 83:173-184. 1927.

3. Bliss, M. C., The Vessel in Seed Plants. Bot. Ga'z. 71 :314326. 1921.

4. - - The Tracheal Elements in the Ferns. Am. Jour. Bot. $26: 620-624.1939$.

5. Brown, F. B. II., Scalariform Pitting a Primitive Feature in Angiospermous Secondary Wood. Science 48:16-18. 1918.

6. Cheadle, V. I., The Occurrence of Vessels in the Monocotyledonae. Amer. Jour. Bot. 26. Supplement p. 9s. 1939. 
7. De Bary, pp. 155-171.

8. Duerden, Il., On the Oecurrence of Vessels in Sclaginclla. Ann. Bot. $48: 459-46 . \overline{3} .1934$.

9. Eames and MacDaniels, pp. 59-62, 64-67, 86-97. 150-153, 162-188.

10. Esau. K., Vessel Development in Celery. Hilgardia 10:479488. $19: 36$.

11. - Ontogeny and Structure of the Phloen of Tobaceo. Ililgardia $11: 343-424$. $19: 38$.

12. Esan, K., and Hewitt, W. B., Structure of End Walls in Differentiating Vessels. Ililgardia 13:229-244. 1940.

13. Frost, F. I1., Histology of the Wood of Angiosperms, I. The nature of the pitting between traeheary and parenehymatous elements. Bull. Torr. Bot. Club $56: 259-264$. 1929.

14. Haberlandt, pp. $302-325$.

15. Jeffrey, Ch. IV and VII.

16. Kellog, R. S., Pulpwool and Woodpulp in North Ameriea. N. Y., 192:3.

17. Stover, E. L.. 'The Vascular Anatomy of Calamovilfa longifolia. Uhio .Jour. sici. 24:169-179. 1924. 


\section{Exercise XI}

\section{SIEVE-TUBE ELEMENTS}

I. Introduction.-The phloem of rascular plants, hike the xylem, is a "complex tissue", which may consist of four or five different types of cells. Nevertheless, the phloem is morphologieally well defined by the eonsistent presence of a highly specialized kind of eell known as a sicve-tube element or sieve-cell. This definitive eell type lacks a uucleus at maturity and in addition possesses other structural and phrsiological properties which are apparently unique. In many angiosperms, the sieve-tube elements are clearly arranged in definite vertical scries, to each of which the collective term "sicve-tube" may be applied. The term sieve-tube has also been given to the individual enucleate cells typical of the phloem in gymmosperms. Such cells, however, are not arranged in linear series. Abbe and Crafts (1939) refer to these structures in conifers as "sieve elements." As Esan (1939) has pointed out in a thorongh review of the literature on phloem structure, the word "sieve-tube in its original meaning had reference to a series of superposed cells with transverse or somewhat inclined end walls bearing sieve-plates." Yndel" such eircumstances, the term "sieve-tube", will be reserved in this book for definable vertical cell-series and the term "sievetube element" nsed for the individual member's of such a series. Similar cells of the phloem of gymmosperms, not arranged in vertical superposed series, will be designated as "sieve-eells."

In angiosperms, the sieve-tube elements are usually accompanied on one of their lateral walls by small prismatic or tubular cells. These cells, which are intimately connected with the sievetubes, are termed companion cells and differ from the sieve-tube elements in possessing nuclei and in lacking definite sieve plates. Companion cells are to be regarded as sister cells of the sievetube elements since both types of cells originate by the division of a common mother cell (cf. Esau, 1939, pp. 409-410). Sieve- 
cells in the gymmosperms lack companion cells in the above sense, but speeialized "albuminous cells" oeeur and have been regarded as equivalent to the companion cells in angiosper'ms. However, Abbe and Crafts $(1939$, p. 710$)$ have questioned this analogy since the albuminous cells "do not arise from a common fusiform initial with the sieve-tube but from separate ray initials." The primary phlocm is usually relatively simple in structure, consisting of sieve-tubes, companion cells and phloem parenchyma as in Cucurbita or only the first two types of eells may be present (e.g., Zca Mays). But secondary phlocm may be very complex because of the presence of fibers, stone cells, vertical phloem parenchyma and rays in addition to sieve-tubes and companion cells. (Cf. Eames and MacDaniels, Ch. VIII, and Esau, 1939, pp. 411-413.)

Aside from the secondary functions of food storage and support, the chief physiologieal role of phloem is the conduction of various organic solutes. Experimental studies on trausloeation (ef. Crafts, 1939a and 1939b) seem to indicate elearly that the main channels of transport for organie materials, and also of eertain viruses are the sieve-tube elements. As to the meehanism of this movement in sieve-tubes there is, however. considerable disagreement. (rafts (1939a) on the basis of a wide series of recent stulies on this problem has developed a "pressure flow" theory which he summarizes as follows: "In the pressure flow mechanism, solvent and solute are assumed to flow together as a solution through elements of specialized structure or permeability, the protoplasm of which plays an entirely passive role in the process. The somrees of energy in this mechanism lie in the osmotic activity of the products of assimilation in green portions of the plant and in the aceumulative ability of cells in growing and storing tissues." Other explanations of the mechanism of transpont in sieve-tuhe elements assume that protoplasmic streaming or highly-active protoplasm is concerned in some way with the process. One result of the lively interest in the function of phloem has been a series of exploratory studies on the structure and development of sieve-tube elements (cf. Esau, 1938). The reeent literature in this fied, as well as the historieal background of the various problems, have been discussed recently by Esau 
(1939) and the following resume on sieve-tube elements is intencled simply as an introdnctory guicle.

1. The protoplast of sicve-tube elcments. One of the most typical characters of the mature sieve-tube element is the absence of a nucleus. Numerous developmental studies (cf. Esan, 1939, p. 375 and 1941 , pp. $452-454$, Pl. 7 ) have shown that while the young clement possesses a normal nucleated protoplast, maturation is accompanied by the eventual disintegration of the nncleus. Prior to its breakdown, the nucleus has been observed to increase significantly in size and to lose its chromaticity. Crafts (1939a, p. 176), in particular, has stressed the physiological significance of the enucleate condition in the sieve-tube element as follows: "The whole history of the sieve-tube portrays the intimate relation of the nucleus to the structure and function of the elements. No student of ontogeny can fail to sense the influence that the loss of nuclens has upon subsequent activity. From the beginning of its functioning period to its death, the sieve-tube element is doomed to a passive rôle, conditioned by its lack of nucleus and consequent permeability." A peculiarity of the eytoplasm of mature sieve-tube elements consists, according to the investigations of Crafts, in its highly permeable nature. Following the disappearance of the nucleus, Crafts finds that cytoplasmic streaming ceases and the cytoplasm "fails to plasmolyse in hypertonic solutions." Furthermore, the cytoplasm in the mature element loses its former ability to acemulate nentral red, a vital stain. Crafts (1939a, p. 17.j) interprets these facts as indicating the highly permeable character of adult sieve-tube elements. As Esau (1939, p. 403) has pointed ont, the enucleate and permeable cytoplasm of mature sieve-tube elements is not to be regarded as "dearl." This appears to be demonstrated by the continued deposition of callus on the sieve-plates during late stages in ontogeny. The contents of mature sieve-tube elements of certain species (e.g., Cucurbita) consist of slimy proteinaceous material which, in sections of phloem treated with heat or alcohol, may coagulate on the sieve-plates and in the lumen to form fummelshaped structures known as slime-plugs. (Cf. Eames and MacDaniels, pp. 193-194, Figs. 90C and 91C; and Esau, 1939, pp. 379-383). The most recent evidence supports the belief that 
slime-plugs are artifacts rather than structures peculiar to normal minjured sieve-tube elements. The slime in sieve-tube elements originates from the disintegration of the slime-elrops which are commonly present in angiosperms as inclusions in the eytoplasm of young cells ; the disintegrated nucleus and the sieve-tube sap also become part of the slimy contents of the sieve tubes. In many plants, leneoplasts and starch gruins may be observed in the sieve-tube elements (ef. Esau, 1939, pp. 38t-386).

2. Sicre-plates and sicue-ficlds. In addition to the nltimate loss of the mucleus, the mature sieve-tube element is characterized by the presence of sicec-plates which oceur in various regions of the eell wall. The origin of the term "sieve-tube" rests upon the erroneous idea that, in such a plant as Cucurbita, the endwalls of the elements are perforated like a sieve. But modern studies agree in showing that sieve-plates are not literally open, perforated areas in the wall. On the contrary, the so-called pores in the sieve-plate appear to be penetrated by either delicate or rather coarse plusmodesmatu. Crafts (1939a) has concluded that these eytoplasmie strands, which thus connect the protoplasts of adjacent sieve-tube elements, are solid rather than tubular in structure as was maintained by certain earlier workers. Considerable variation oecurs with reference to the distribution of sicve-plates in sieve-tube elements. In highly specialized sievetubes (e.g., in Cucurlitu), the transverse end-wall is oceupied by " single large plate with rather coarse plasmodesmata while the lateral walls are provided witl smaller, less distinct plate-like areas. But several sieve areas forming a "compound sieve-plate" may be present in end-walls which are inclined ol" sloping. In the grmmosperms, very umerous small sieve-plates or "sievepits" oecur on the ratial lateral walls ( $A$ bloe and ('rafts, 19:39). The term "sieve-field" was originally applied by Nägeli to the apparently reduced sieve-plates present on the lateral walls of angiospermous sieve-tube elements. However, as Esan (19:39, p. 395) has clearly indicated, sieve-plates and sieve-fichds may intergrade in structure so that only an arbitrary distinetion ean be made between them. The morphological nature of the sieveplate is still, to some extent, an unsolved problem. This is largely the anse becaluse of the many gaps in our knowledge as to the 
method of development of these structures. Furthermore, the terminology used in describing the adult sieve-plate and its homolognes is, as Esau (1939) has shown, in a confused state. It does seem evident, however, that in some respects, sieve-plates are fundamentally similar to simple pits (Esau, 1939, pp. 397 399). In conifers, the sieve-plates arise directly from the large primordial pits which are present on the radial walls of the youmg sieve-cells. Also in many angiosperms, it is possible to trace the origin of the sieve-plate to a primordial pit of a meristematic cell. In some plants, lowever, such as Robinia and Cucurbita, it does not appear possible to refer the large solitary sieve-plates on the end-walls to development from a single primary pit area. Esau suggests that in Robinia "one might assume that several shallow primordial pits together form one sieve-plate, the single or numerous plasmodesmata of one pit giving rise to one connecting strand of a sieve-plate." During the development of the sieveplate, each plasmodesma or in gymmosperms each group of plasmodesmata beeomes surrounded by a eylinder of callus. The chemical nature of this substance is still in question but calluscylinders are readily stained and differentiated by treating sections with aniline bluc. As the maturation of the sieve-tube element progresses, the amount of callus on the sieve-plates increases so that the originally separate cylinders beeome confluent or fused and the plate becomes coated on both sides with callus. Aceording to Esan (1939, p. 391) this final acemulation is "definitive-callus" and indicates "the approach of a functionless state of the sieve-tube." There appears to exist no eonclusive eridence that definitive-callus bloeks up the pores of the sieveplate. On the contrary, the plasmodesmata are noticeably stretehed and eventually die. In many plants, the definitivecallus becomes dissolved away from the plate prior to the death of the sieve-tube elements and their companion cells whieh eventually become obliterated or erushed by neighhoring cells.

3. Lateral uells of sieve-tube clements. The lateral walls of reeently differentiated sieve-tube elements are frequently thick and glistening in untreated sections. They have been termed "nacre" beeause of this appearance. Chemically, these walls appear to eonsist of cellulose and probably are, morphologically, 
primary walls. In various members of the Abietineae, however, Abbe and Crafts (1939) reported true secondary walls in the sieve-elements of the secondary phloem. According to Esau's review, the nature of the pits or protoplasmic comnections of sieve-tube elements with companion cells and phloem parenchyma cells is not yet definitely established. In some cases at least, the wall between the sieve-tube element and its companion cell is penetrated by numerous seattered plasmodesmata.

\section{Material for the Study of Sieve-Tube Elements.--}

1. The phlocm of Cucubita. Obtain a thin transverse section of the stem of pumpkin and examine its structure under low magnification. In progressing from the edge of the section towards the center the following tissues may be observed, viz.: (1) a typical miseriate cpidermis, certain cells of which have developed into hairs; (2) a rather narrow cortex, consisting of an outer, discontinuous zone of angular collcnchyma followed by a region of parcnchyma the innermost layer of which may contain abumdant starch grains and appear as a sturch-sheath if the section is stained in iodine; (3) the stele, the outer boundary of which is clearly indicated by a continnous eylinder of thickwalled pericyclic fibers. Internal to the fibers occurs a broad parenchymatous zone in the imner portion of which are found two "lings" of vascular bumales. Each bundle consists of a median strand of xylem (eharacterized by its large vessels) flanked on both sides by a strand of phlocm. A bundle of this type is designated as a bicollateral vascular bundle. Clear evidence of a cambial zone may be seen between the xylem and each of the pliloem strands, especially in the larger inner bundles. The center of the stem is ocenpied by an irregular cavity which was produced hy the collapse and disintegration of the pith. To investigate the strueture of the phlocm, remove the eover-glass and momnt the section in a $.1 \%$ aqueons solution of aniline blue. ${ }^{1}$ This dye will stain the callus depositions on any of the sieveplates which may be present in the section. A eareful study, under high magnification, of the phloen of the varions bi-collateral bundles will usually reveal a umber of large sieve-plates. These structures in Cucurbita oceupy virtually the entire end-

1 Cf. Appendix, p. 142. 
wall of the eylindrical sieve-tube elements. In critically stained sieve-plates, each "pore" is ocempied hy a dark central spot, representing the large plasmodesma and is surromded by a distinct callus-cylinder stained a light bhue. If definitive-callus has not yet appeared, the portions of the plate between the calluscylinders should appear unstained. Note that in addition to the sieve-tubes, smaller companion colls appear and are distinguished by their mucleated protoplasts and their triangular or yuadrangular form as seen in trans-section. Phlocm parenchyma is also present but is diffieult to distinguish from sieve-tube elements unless the latter exhibit sieve-plates. This study of phloem should be continued with the aid of longi-sections which likewise should be stained in aniline blue. Note earefully the appearance and structure of the sieve-plates as seen in sectional view, and the relation of the siere-tube elements to the companion cells and the phloem parenchyma. Often slime-plugs will appear in certain of the sieve-tube elements. They can readily be induced by treating the section with $70 \%$ aleohol.

2. The phloem of Robinia and Pinus. MIomt thin radial and tangential sections cut from living twigs of these genera in a $.1 \%$ aqueous solution of aniline blue and study under high magnification the structure and distribution of the sieve-plates and the form and relationship of the sieve-tube elements and sieve-cells.

\section{Suggested Drawings and Notes.-}

1. Diagram the general structure of a bicollateral bundile from the stem of Cucurbita as seen in trans-section. Label all essential parts and indicate by eircles the position of the largest vessels of the xylem.

2. Draw small portions of the phloem tissue of Cucurbita as seen in both trans- and longi-sectional views. Show carefully the structure of at least one sieve-plate in each drawing. Label all cell types and structures.

3. Prepare drawings of small portions of the phloem of Robinia and Pinus to show the form and structure of the sievetube elements and sieve-cells.

4. Summarize the evidence which indicates that plant viruses may move and be transmitted through phloem tissue (cf. Crafts, 1939b, and Esau, 1941). 
5. Outline briefly the experimental evidence as to the role of the phloem in the trans-location of organic solutes (ef. Crafts, 1939b).

\section{REFERENCES}

1. Abbe, L. B., and Crafts, A. S., Phloem of White Pine and Other Coniferous Species. Bot. Gaz. 100:695-720. 1939.

2. Crafts, $\Lambda$. S., The Relation between Structure and Function of the Phloem. Amer. Jour. Bot. 26:172-177. 1939a.

3. - Movement of Viruses, Auxins, and Chemieal Indieators in Plants. Bot. Rev. 5:471-504. 1939b.

4. Eames and MacDaniels, pp. 69-76 and Ch. VIII.

5. Esan, K., Ontogeny and Strueture of the Phloem of Tobacen. Hilgardia $11: 343-424.1938$.

6.

Development and Structure of the Phloem Tissue. Bot. Rev. 5:373-432. 1939.

7. Curly Top and Mosaic. Hilgardia 13:437-490. $19+1$.

8. Hayward, pp. 614-616. 


\section{EXER'ISE XII}

\section{THE S'TEM}

I. Introduction.-In this and the two following exercises, a brief study will be made of the comparative anatomy of the three principal vegetative "organs" of the sporoplyte of seed plants, viz.: the stem, leaf, and root. Paleobotanical evidence shows clearly, however, that this conventional subdivision of the plant body cannot be applied to the Psilophytales which are generally regarded as the most primitive of all tracheophytes. Indeed, in the Psilotales, which are the living representatives of this ancient group, roots are absent and the aerial portion of the sporophyte is not clearly demarcated into stem and leaves. Furthermore, it is clear that even in seed plants the boundary between stem and leaf can only be made rather arbitrarily. Both of these "organs" arise from a common terminal meristem (i.e., the shoot apex) and their further differentiation and growth is reciprocal and interdependent to a large extent. For these reasons, it seems preferable, from a morphological standpoint, to inchude both the axis (i.e., the stem) and its foliar appendages under the broader concept of the shoot. This concept has found application not only to the vegetative region but has also been widely adopted in the anatomical interpretation of the flower of angiosperms (cf. Eames, 1931, and Foster, 1939). Heince, in this book, the separate treatment given to the stem and the leaf is largely a matter of practical convenience and its limitations on morphological grounds should be constantly borne in mind. (Cf. Arber, 1941, for a penetrating discussion of the problem.) The root, which is axis-like in form, clearly deserves separate discussion and study and its anatomical features will be outlined briefly in Exercise XIV.

In the followng resume of the basic aspects of stem anatomy, the listology of the internodal regions of this structure is the principal consideration. The nodal regions of stems, because of 
the complications in vascular anatomy resulting from the development of leaves and buds, offer a series of problems which are beyond the scope of the present book. In general. however, it may be stated that in grmmospems and dicotyledons, the eylinder of vascular tissue is interrupted at or near the node by the development (early in ontogeny) of leaf gaps, which are parenchymatous areas in the siphonostele situated above the point of divergence of the leaf traces. Depending upon the nature of the foliar structure as well as upon the plant, the anatomy of the node is described as unilacunar (one gap), trilacunar (three gaps) or multilacunar (more than three gaps). There appears to be some evidence that in angiosperms the trilacunar node is the primitive condition. (For further details ef. Eames and MacDaniels, pp. 114-120.) The development of the axillary bud results in additional complications in the rascular anatomy of the node. The earliest vasenlar bundles of the bud are known as branch traces and their" "divergence" from the main axis likewise is associated with parenchymatons areas in the stele which are termed branch gaps. Wide application of the principals of nodal anatomy has been made in the study of the vascular anatomy of the flower ('f. Eames, 1931, and Wilson and Just, 19:39).

1. The primary structure of the stem. In many of the lower vascular plants and in certain herbaceons angiosperms (particularly monocotyledons), all the stem tissues are primary, i.e., they originate directly from the progressire differcutiation of cells derived from the apical meristem of the shoot. Despite the great variation in the kinds and patterns of tissues, a common plan of primary struetural orwanization is fomm in the stems of most gymmosperms and angiosperms. 'This consists in the existence of three more or less well-demareated zones or regions which now may be deseribed briefly as follows:

(a) The epidermis. Stems possess a well-defined epidermis in which stomata and varions types of trichomes may be present in addition to typieal epidermal cells (ef. Exercise V).

(b) The eorter. Beneath the epidermis of stems is found a eylindrieal zone, variable in its radial dimension and in the kinds of eells which ocenr. This region is the cortex and in the simplest 
condition is formed of thin-walled parenchyma tissue. Often, however, the cortex is morc complex histologically and exhibits an outer, subcpidermal area of collenchyma (which oceurs as a continuous cylinder or as separate strands) and an inner region of parenchyma. Other cell types may also appear in the cortex, particularly selereides, fibers and secretory cells.

(c) The stcle. This region of the stem includes the primary vascular tissues as well as variable amounts of parenchyma:

Since the original formulation of the "Stelar Theory" by Van Tieglem and Douliot in 1886. comparative studies on the stem have largely centered upon the organization and phylogeny of the stele, particularly with reference to the distribution of phloem and xylem and the morphological nature of the pith. It is now rather generally held that two principal types of steles occur in the sporophyte of vasenlar plants, viz.: (1) the protostcle, which consists of a central core of xylem ensheathed by phloem, and (2) the siphonostele which is characterized by the presence, internal to the protoxylem, of a central mass of parenchyma known as the pith. The evidence from comparative anatomy, including the facts of paleobotany, supports the idea that the protostele is the primitive type. This type of stele is found in both the stem as well as the root of many lower tracheophytes but is restricted to the root of seed plants. The order of maturation of the tracheary elements of the xylem in a protostele is centripetal and primary xylem of this kind is termed exarch. In contrast, the protoxylem in a siphonostele is sitnated at the outer edge of the pith and the order of maturation of the xylem is centrifugal. Primary xylem in the stems of seed plants is thus cndarch. A discussion of the involved controversy as to the way in which the siphonostele may have originated from the protostele is beyoud the scope of this book and the student is referred to the excellent resumés given by Eames and MacDaniels (pp. 112-114 and 337-340) and Smith (1938, pp. 124-131). In the writer's opinion, however, the evidence from ontogeny appears to favor the idea that at least in seed plants the pith region is morphologically a part of the stele and represents the parenchymatization of potential vascular tissue. As seen in transsection, the vascular tissue of the siphonostele appears either as 
a eontinuous cylinder, broken only by the short leaf gaps in noclal regions, or" as a "ring" of vascular bundles. A stele of the latter" type should be visualized as a tubular network, the "meshes" representing the long vertieal leaf gaps or parenelymatous rays. This kind of stele is termed a dictyostele and its component bumdles are either collateral or bicollateral. In gymnosperms and dicotyledons, the siphonostele is specifically designated as cctophloic if there is only an external area of phloem, or as amphiphloic if both internal as well as external phloem oecurs. This latter type of siphonostele is restrieted to eertain families in the dicotyledons and also appears in the stems of some ferns. The nature of the boundury between stele and cortex has produced much diseussion among anatomists. A common view is that the endodermis represents the innermost layer of the eortex and that hence all tissues internal to it, including the pericycle, vasculur tissues and pith, eonstitute the stele. Such a demareation is practical in roots whieh typically develop a well-defined endodermis, and the evidenee of ontogeny indieates that at least in some plants, the endodermis is morphologieally a part of the cortex (cf. Esan, 1941). In the stems of seed plants an endodermis or its equiralent (i.e., the so-called "starch sheath") may be present. Inder such eireumstances it should be elear that until further ontogenetic evidence becomes available, only an approximate and somewhat arbitrary demareation can be made in many stems between the innermost region of the cortex and the alljacent pericycle.

2. The ontogeny of the stele in vascular plants. Within reeent years there las been a marked levival of interest in the origin and differentiation of the primary vaseular system. Among the more important eontributions may be eited the work of IIelm (1932), Barthelmess (19:35), Louis (19:35), Kaplan (1937), and Grégoire (1938). One of the principal objectives in these investigations has been to determine how the provascular tissue or proeambium is produeed from the tissue of the shoot apex. In view of the involved aspects of this process, it will only be possible to outline certain important steps.

In a number of dicotyledons, the first stage in the determination of the position of the provascular tissue consists in the early 
clifferentiation of the pith. 'This sets apart, near the base of the shoot apex, a peripheral ano of tissue which shows little or no evidence of specific differentiation. The next step, as one proceeds away from the summit of the apex, is concerned with the effects produced by the developing leaf primordia. These structures early assume a dorsiventral character and their abaxial regions begin early to develop as parenchymatous tissne. As a result, at least in many dicotyledons, trans-sections below the base of the shoot apex, show a more or less distinct "ring" of cmbryonic tissue demarcated on the outside by the united bases of the leares and on the inside by the developing pith. This tissue zone has been designated by Helm as the "meristem ring" and by Louis as the "prodesmogen." From it there is produced the provascular or procambial cells which ultimately give rise to the primary vaseular system of the stem.

Divergent ideas are held as to the way in which procambium arises from the meristem ring or prodesmogen. According to one view, the procambium arises as isolated strands in the bases of the young leaf primordia, from which points its further differentiation proceeds acropetally towards each leaf apex and basipetally towards the prodesmogen tissue in the axis. IInwerer. a number of recent studies (e.g., Boke, 1940, 1941) suggest that this may be an erroneous interpretation and that the development of provascular tissue in the region of the shoot apex may be exchisively aeropetal.

One of the important aspects of recent studies has been to emphasize the interrelationship which exists between stem and leaf in the bnilding up of the stele. This is shown by the fact that in conifers and many dicotyledons, the first vascular bundles in the young siphonostele are leaf traces or so-called "common bundles." The interfascicular arcas in the "meristem ring" may either produce additional procambial tissue from which additional primary xylem and phloem arise, or as in dictyosteles, progress towards the formation of parenchyma. In the latter case, the interfascicular strips either mature as trpical modullary rays or give rise to an interfascicular cambium.

The question of the differentiation of primary phloem and primary xylem in leaf traees has apparently received only meagre 
study. Aceording to the work of Esan (1938, p. 396) on tobaceo, the primary xylem differentiates both upwardly into the leaf and downwardly into the axis. But "the phloem of a leaf trace follows a different course of development from that of xylem. It differentiates, at least in the species considered in these studies, acropetally from the stem into the leaf.'

3. The secondury structure of the stem. In gymnosperms and many angiosperms, the so-ealled primary tissue regions are relatively short-lived and eventually are destroyed or embedded by the development of secondary tissues. As pointed ont in Exerrise $\mathrm{X}$, the distinction between primary and secondary vaseular tissues is rather arbitrary and depends fundamentally upon the way in which "procambium" is distinguished from the "vascular cambium." The process of secondary growth in stems is extrenely complex and the following outline is intended merely as an introductory guide. (For a detailed treatment ef. Eames and MacDaniels, Ch. VI.)

The vascular cumbium, theoretieally regarded, is a uniseriate meristem eomposed of ray initials, which produce the rascular rays, and fusiform initials which give rise to the "vertical" cell types in the secondary phloem and secondary xylem. In examining developing siphonosteles in trans-scction, however, it proves diffienlt or impossible to distinguish the cambial initials from their most recent derivatives. For this reason, the ter'm "eambial zone" may be used collectively to designate the cambial initials and their adjacent molifferentiated phloem and xylem mother cells. The vasenlar cambium may be thought of as the direct rontinuation of the molifferentiated procambial tissne situated hetween the metaxylem and the metaphloen. If one is eoncerned with a dietyostele, a distinction is made between the eambium within each bundle (the fascicular crmbium) and the eambium which arises from parenchyma-like tissue between the bundles (interfascicular combium). The latter may produce additional phloem and xylem or as in certain vines, broad rays of "seeondary" parenchyma. The effects of sustained "ambial aetivity" upon the primary tissue regions is profomol. All extra-cambial tissnes, i.e., primary phloem, pericycle, cortex and epidermis, are affected and eventually, through the added activity of the 
phellogen or cor'k cambium, are sloughed away. 'Their place is gradually taken by the bark which consists in many gymosperms and dicotyledons of dead or dying secondary phloem and of areas of periderm. The intra-cambial primary tissues, i.e., primary xylem and pith, are completely buried within the cylinder of secondary xylem and, as a result of stretching and compression, may be erushed or even destroyed.

The early phases in development of secondary vascular tissues in woody stems are usually accompanied by the formation of a periderm or corky tissue beneath the epidermis. Functionally, the periderm acts as a protective layer, replacing in this respect the epidermis which is eventually killed and sloughed away. Structurally, the term periderm is applied to the phellogen or cork cambium and its two derivative tissues, viz. : cork or' phellem, and phelloderm. The first-formed phellogen in the stem appears to arise as a result of the regressive differentiation of epidermal, cortical or pericyclic parenchyma cells. Its initiation is indicated by the tangential division of certain cells. In some species, these first tangential divisions appear in the epidermis. Most commonly, perhaps, the phellogen originates in the outermost cells of the cortex. There is evidence that in some stems, the cortical phellogen first makes its appearance bencath the stomata, at which point lenticels are produced. Continued spread of the phellogen from these structures may result in the formation of a cylinder of cork cambium. As a result of the repeated tangential division of the phellogen cells, the derivative tissues exhibit alignment of the cells in radial rows. Cells differentiating towards the outside of the phellogen lose their protoplasts, acquire subcrin in their unpitted walls, and finally matme as cork cells. The phelloderm tissue, which is usually much less in extent than the cork, originates from the imner derivatives of the phellogen. Phelloderm cells are described as being parenchyma-like in repining their protoplasts and in having simple pits in their cellulose walls. The functional life of the first-formed phellogen in woody stems is short and new layers of cork cambium arise successively from deeper regions of the cortex and pericycle until, finally, the living cells of the secondary phloem participate in periderm formation. The ultimate result is the production 
in many species of shell-shaped layers of periderm which enclose masses of dead or dying phloem tissue ( $\circ$ f. Eames and MacDaniels, p. 21:, Fig. 96).

The first-formed as well as later developed perider'm laver's in stems are usually provided with aeruting structures termed lenticcls. As stated above, lenticels are usually initiated by the appearance of a phellogen beneath a stoma (cf. Eames and MacDaniels, p. 219, Fig. 100). In the development of a lenticel, the phellogen. instead of produeing typical cork, forms a mass of loosely-arranged cells with unsuberized walls which make up the complementary tissuc. This tissue in many lenticels may be subdivided by lavers of smaller more compact eells which are termed closing layers. The pressure exerted by the outwardly-developed mass of eomplementary tissue is sufficient to rupture the epidermis which, together with the underlying layer's of adjacent cork, enrls back from the edges of the lenticel as flaps of broken tissue. In many plants (e.g., sambucus), the extruded complementary tissue is very prominent. Aceosding to De Bary (p. 561) the puffy swelling of lenticels in trees during wet weather may be the result of the "hyoroscopicity" of the complementary" tissue.

\section{Material for the Comparative Study of the Stem.-The} choice of material for the study of stem anatomy will depend upon the forms available as well as upon the points to be illustrated. The following stem types have proved useful and are recommended. Free-hand sections of stems stained with phloroglucinol and hydrochloric acid ane of considerable use. lint for the finer details of structure and development, permanent mounts of aritically stained sections are necessary.

1. The stem of the gerenium (Pelurgonimm sp.). Examine a transerse scetion of the stem, and stuly the following tissues and regions from the edge of the section inwardly, viz:

(a) The epidermis, a uniseriate layer ol' small oval or elliptical cells with thick imner and onter walls (the latter corered with a thin cuticle) and somewhat thinner radial walls. A protoplast. which may appear somewhat collapsed, should be evident in most cells. ('ertain of the epidermal cells have given rise to stomata.

\footnotetext{
1 cf. Appendix, p. 140.
} 
while other's have developed to various tryes of trichomes, including glandular eapitate hairs and multiceltular umbranched hairs, the latter similar to the hairs already studied on the geranium leaf. (Refer to Exercise V.)

(b) Immediately within the epidermis is found the cortex, a region composed of twelve or more layers of rather typical "isodiametrice" parenchyma cells which are separated from one another by prominent intercellular air spaces. A protoplast is present in many of these cortical cells, the main functions of which are photosynthesis and food storage, as is evidenced by the frequency of starch grains in these cells; druses of ealcium oxylate are found in many of the cortical cells, occupying nearly the whole cavity of the cell.

Depending largely on the distance from the shoot apex at which the sections on your slide were taken, you will find the early or later stages in the development of cork or phellem. In studying the phellem in the stem of the geranium, notice that druscs are occasionally found in some of the inner cork cells. If your sections show a phellem four or five layers in thickness, you will find that the tangential (and to some extent the radial walls) are somewhat way or irregular. This condition, which is very commonly found in corky tissue, results from the constant pressure of the successively dereloping and enlarging cork cells upon the older cells of the phellem. Typical phelloderm, however. is rurcly developed in the young stem of the geranium.

(c) Directly inside the innermost layer of cortical cells occurs the stcle, the outer region of which is indicated by the pericycle which in the geraninm stem consists of an outer continuous ring of thick-walled pericyclic fibers (elongate tightly joined cells, as seen in longitudinal section, with characteristic slit-like spirallyarranged pits) followed by several layers of small thin-walled parenchyma colls. The vascular tissue of the stele lies directly within the pericycle and consists of a ring of typical collateral bundles (i.e., bundles in which the phloem lies radially cxtcrnal to the xylem) which are separated from one another, at least in certain regions, by strips or bands of parenchymatous tissue which becanse of their direct connection with the pith (medulla) may be termed medullary rays. 
In view of the obvious rariation in the size and degree of development of the raseular bundles in any given section, the following deseription is only general in nature; and all essential variations and details must be indivdually interpreted.

A well-developed iascular bundle in the geranium stem is somewhat wedge-shaped or triangular in cross-section and consists of an external region of phloem tissue separated from the internal region of xylem tissue by the cambial zone in which cell divisions oceur predominately in the tangential plane.

Beginning with the phloem tissue of the bundle first of all, you should be able to find the somewhat crushed primary phloem lying directly against the immermost cells of the pericycle; structurally. primary phloem in the geranium stem appear's to consist of small sieve-tubes, companion cells and phloem parenchyma. Lying directly inside of the primary phloem occurs the secondary phloem which is composed of (1) sicve-tubes, rather large polygonal cells, apparently devoid of contents; (2) companion cells, extremely small, more or less trinngular cells (in cross-section of conrse) closely joined to the sieve-tubes and usually containing a definite nucleated protoplast; and (3) large thin-walled parenchyma cells.

Separated from the secondary phloem by the "cambial zone" occurs the xylem tissue of the vascular bundle. In all of the larger bundles, the xylem is of two linds. viz.: (1) secondary rylem, an external layer of thick-walled isodiametric, tightly joined cells which are arranged in more or less definite radial rows because of their origin from the fascieular cumbium: and (2) the primary xylem, an internal group of rather large, more or less polygonal cells, irregularly arranged and imbedded among isodiametric thin-walled parenchyma eells. The smallest cells of the primary xylem (which has differentiated centrifugally from the procambial strand) are found nearest the imner edge of the vaseular bundle and represent the first formed elements of the protoxylem. Notiee partienlarly that in many protoxylem cells, portions of the spiral thickening have heen torn from the wall in the process of sectioning: in other cells, a picee of the spiral band may be seen projectingr into the lumen of the cell. 
From what has already been said of the structural characteristics of the tracheary cells of the xylem, it is almost unnecessary to state that the limits between secondary xylem and metaxylem are virtually impossible to determine when considering only transverse sections of a vascular bundle. In the interval between each of the individual bundles in the ring, there oceurs a zone of small thin-walled, obviously meristematic cells which are continuous with the cambial zone in the bundles themselves and represent what is termed the interfascicular cambium. The interfascicular' cambium originates by the tangential division of cells in the medullary rays adjacent to the strips of fascicular cambium. In certain plants, the interfascicular cambium only forms parenchyma (e.g., Clematic, Aristolochia) but in Pelargonium, as in many herbaceous plants, the interfascicular cambium gives rise to additional "bundles" composed entirely of secondary phloem and secondary xylem; the extensive development of vascular tissue from the interfascicular cambium usually results in the formation of a complete cylinder of secondary xylem and phloem. In studying the sections note that phloem is the first vascular tissue to differentiate from the interfascicular cambium and is later followed by the centripetal formation of secondary xylem; whether this is an exceptional condition can only be determined by the investigation of a large number of herbaceous stems.

The center of the stele is occupied by the pith, which is composed exclusively of large isodiametric thin-walled parenchyma cells separated from one another by conspicuous intercellular airspaces. The extreme abundance of starch grains in the cells of the pith indicates that this region has as its function the storing of reserve food material.

2. The stem of the basswood or linden (Tilia sp.). Obtain a stained slide with transverse, radial and tangential sections of the stem. Examine first the trans-section and study the following tissues and regions from the periphery of the stem to its center, viz. :

(a) The epidermis, a uniseriate layer of cells which appears broken and cracked in uumerous places dne to the development of a prominent periderm beneath it. Structurally the cells of the epidermis are rather small, are oval in shape (in section view) 
and possess thick, slightly stratified outer walls orerlaid by a cuticle; in most instanees, inclusions and the remains of the disintegrated protoplast are present in the epidermal cells.

(b) Immediately within the epidermis oceurs the periderm which is composed of three layers of tissue, riz.: (1) the phellem or eork which is differentiated centrifugally from the phellogen and eonsists of a varying number of layers of narrow, laterally compressed cells which are arranged in definite radial rows and are densely packed (except the two outermost layers) with dark brown material which eonsists probably of substanees classed un. der the general head of tannins; (2) the phollogen which is a uniseriate layer of meristematic cells found next to the innermost layer of phellem cells. In Tilia, as in so many woody stems, the phellogen is initiated by the tangential division of the outermost layer of eortical cells. (3) Internal to, and directly next to the phellogen oceurs a single layer of cells charaeterized in this instance by their rectangular form and obrious protoplasts. This layer of cells is known as the phelloderm and differentiates centripetally from the phellogen. Note that the corky layer of the stem is definitely broken at certain points which appear as somewhat lens-shaped areas; these regions are known as lenticels. In studying the structure of the lenticels of the basswood stem, observe particularly the eontinuity between the phellogen and phelloderm of the lenticel and these tissues as they oceur at either side of the lenticel. In this particular developmental stage of the stem in Tilia the lenticels have been formed from the first or primary eork cambium; as the stem increases in diameter from year to year, new lenticels are formed at various points on the surface of the bark by the aetivity of subsequently formed phellogen layers; thus even in relatively old branches, lenticels develop and represent the neeessary areas through which exchange of gases between the living tissues and the atmosphere ean take place in the essential process of respiration.

(c) Directly internal to the periderm oecur's the cortex, whieh consists of two rather definite regions, viz.

(i) An outer region eomposed of four or more layer's of collenchyma eells, which in the position of their thickened primary walls appear intermediate in charaeter between "angular" 
and "lamellar" collenchyma. Notice that intercellular air spaces are extremely small and difficult to distinguish.

(ii) An inner region composed of typical "isodiametlic" parenchyma cells with active protoplasts and cells containing' druses of calcium oxalate. The latter type of cells tend to occur in groups (refer to the radial section of the stem) and their specialized character has earned for them the term of "crystal sacs." It is important to notice the crushed appearance of many of the parenchyma cells in the cortex; this condition has been caused by the pressure of the secondary phloem which is constantly pushed toward the periphery of the stem.

(d) The stele. Tilia possesses an ectophloic siphonostele but the arrangement of the tissues of the secondary phloem shows a number of features distinctive of this genus. The phloem occurs just within the innermost layer of the cortex and consists of a eylinder made up of wedges of tissue showing a characteristic "banded" appearance which alternate with triangular sectors which are "homogeneous" in structure; the wedges showing the band-like structure are broadest next to the cambium while just the reverse relationship obtains in the case of the homogeneous sectors.

Examine in detail, first of all, the structure of one of the large "banded" sectors. You will observe that the characteristic "banded" appearance of such a sector is due to the alternation of tangential layers of extremely thick-walled fibers with layers of thinner walled cells. These thick-walled phloem fibcrs, which provide mechanical support and flexibility to the stem, have long been known as "bast fibers" and their prominent development in the genus Titia is responsible for the old English name of this tree, i.e., "bast-wood" which in modern langnage has been changed to "basswood." Under high power, the phloem or "bast fibers" appear irregularly polyhedral, are closely joined withont evident intercellular air spaces, and possess extremely small lumina ; under especially farorable conditions of magnification and illumination you may be able to see the infrequent canal-like pits between adjacent cells.

The layers of thinner-walled cells alternating with the bands of "bast fibers", are composed of the conducting and storage cells 
of the phloem, viz.: radial rows (one or oceasionally two cells in thickness) of living parenchyma cells formed from the cambium and extending out to the cortex through the phloem; these radial rows of cells (which of course are actually sheets of tissue) are the phlocm rays and are directly continuous across the cambium with corresponding rays of the secondary xylem. The phloem rays function both in radial transportation as well as in the storage of food materials. Starch grains are often present in these cells. The sicve-tubes, which are the important vertical conducting elements of the phloem, appear in transverse section as large somewhat irregular thin-walled cells which appear devoid of protoplasts and are closely joined on their smaller wall-facets with the companion cells. The latter are very small, appear more or less triangular in transverse section and in most cases possess definite nucleated protoplasts. Interspersed among the sievetubes are the small isodiametric phloem parenchyma cells which possess a living protoplast.

Turning now to the wedges of "homogeneous tissue," it will be found that these sectors are entirely composed of somewhat "rectangular" parenchyma cells, most of which are provided with a definite protoplast. The characteristic form of these sectors is due to a process of dilatation of the multiseriate phloem rays lying between the "banded" sector's of the stem. In other" words, certain of the phloem rays (nsually those which are two or three cells in width at the cambinm) increase contimonsly in width ly the radial and tangential division of the parenchyma cells: the intervening areas of phloem (i.e., those containing the bast fibers and the sieve-tubes) are thus separated from each other and correspond in position to the phloem portions of the original vascular bundles. As the stem increases in age, a similar process of dilatation nceurs in the smaller rays of the plibem with the result that the "banded" sectors hecome suceessively" subdivided into smaller groups (for eomplete details, ef. De Bary pp. 536-537). It should be noted that these dilated phloem rays are directly continuous across the cambium with bi- or triseriate xylen rays. Druses occasionally appear in the parenchyma cells of the dilated phloem rays. 
The "cambial zone" occurs directly between the secondary xylem and the secondary phloem and consists of the uniseriate cambium itself and a varying number of layers of "maturing" vascular elements. A careful study of the "cambial zone" will help in moderstanding the direction of formation of secondary xylem and secondary phloem and will furthermore shed some light on the nature of the early developmental stages of the cells making up these tissues.

Within the "cambial zone" occurs the cylinder of secondary xylem which is composed of two or three more or less concentric layers or eylinders of xylem tissue, each of which is known as an annual ring. In all woody stems of north temperate plants, an anmual ring represents the amount of secondary xylem formed during a single growing season. The presence of anmual rings in the secondary xylem of perennial woody plants seems to be determined to some extent by seasonal conditions, since the xylem tissue formed in the spring (the so-called "spring wood") differs somewhat in respect to the sizc, type and arrangement of its cells from that formed in the summer (the so-called "summer wood,"). It is due to this structural difference between "spring", and "summer" wood that an annual ring appears distinct. In many cases, the cells formed during late summer tend to be somewhat smaller and thicker-walled than those arising in the spring; often the difference is emphasized by the localization of the majority of the vessels in the spring wood.

The secondary xylem of Tilia is, like that of many woody dicotyledons, a very complex "tissue system," consisting of the following types of cells :

(a) Vessel elements, which are large prominent cells, rather polygonal in transverse section, and possessing large empty lumina. In especially thin regions of your section you may be able to see small bordered pits in cross-sectional view. Careful focusing should reveal the "componnd middle lamella."

(b) Tracheids, which are smaller in size than the vessels and are often more or less rectangular in shape as seen in transverse section. In contrast to the vessels, the tracheids are frequently arranged in definite radial rows. 
(c) Fibers, which are somewhat irregular in shape and are ustally much smaller than either the ressels or tracheids and are usually provided with thicker walls.

(d) Scattered among' the vessels, tracheids and fiber's, ocenr the rood parenchyma cells which are small in size, isodiametric in form. and possess a definite protoplast. It should be realized that woor parenchyma cells oceur in "vertical chains" or rows and function primarily in the storage of certain carbohydrates. particularly starcli; the function of wood parenchyma in "assistinc" the trans-location of substances in the xylem is inperfectly understood. In Tilia, the wood-parenchyma has no definite distribution in the xylem and is hence termed "diffuse."

Extending radially through the secondary xylem are the rays which are of two types, viz.:

(a) Large rays, which represent the xylem "extension" of the large specialized dilated rays of the plloem discussed previously. In the second annual ring, these large lays may be two or three cells in width but, at least in the inner portion of the first amual ring, they become a single cell in width and finally terminate directly in the pith. Such rays have been termed "primary medullary rays."

(b) small rays, one cell in width which are the xylem extension of the rays extending through the "banded sectors" of the phloem. These rays have been termed "secondary medullary rays" but in some instances at least have no direct conneetion with the pith.

The primary rylcm oecur's next to the pith and is completely surrounded extermally by the cylinder of scomdary xylem. It is natmally very difficult to distinguish between the metaxylem and the first-formed elements of the secondary xylem in a transverse section of the stem of Tilia. The protoxylem, however, is quite distinct and appears as solitary or grouper thick-walled cells which are imbedded among the small parenchyma eells of the primary xylem at the periphery of the pith. The pith is a solich rod of tissue oecupying the center of the stem. In contrast to the condition in the geranium stem, the pith of Tilin is not homogeneous but shows a certain anrount of tissue speeialization als follows: 
The periphery of the pith is formed of several layers of rather thick-walled more or less isodiametric parenchyma cells which are provided with protoplasts and in addition contain very small stareh grains; other of these peripheral cells are filled with dark-staining granular material, the exact natmre of which is obscure at present. The bulk of the pith is composed of large " isodiametric" parenchyma cells which are separated by definite intercellular air-spaces; some of these cells likewise contain small starch grains and protoplasts. Interspersed among these large pith cells occur much smaller thicker-walled parenchyma cells which are filled with granular dark-staining bodies; these latter cells are found singly or in groups, but in longi-section appear in scattered vertical series.

Attention must finally be directed to the mucilage-containing cells which are arranged in a more or less definite ring near the periphery of the pith. These mucilage-containing cells may be identified by their large size, by the disorganized reddish or purple material found in them, and by the jacket of starch-containing parenchyma cells which surrounds each of them. The function of the mucilage formed in these cells is unknown.

3. The stem of Gymnosperms (e.g., conifers) is similar to that of many woody dicotyledons in that the activity of a cambium forms a cylinder of secondary phloem centrifugally and a cylinder of secondary xylem centripetally. A transverse section of a young pine stem shows a number of interesting anatomical features, viz. :

(a) The large cavities or resin canals which appear in the cortex and in the secondary xylem (in the latter region the canals are smaller than those in the cortex). Notice that the resin canal (which has arisen by the pulling apart of groups of cells in certain regions and is hence of the schizogenous type) is bordered by a ring of small, densely protoplasmic secretory cells which exude resinous material into the canal. In certain species of pine, the resin is of great commercial importance and is obtained by "taping" the trees; the resin obtained in this way is the basis of turpentine and allied products.

(b) The sccondary xylem is relatively simple in structure and consists of tracheids, fiber tracheids and uniseriate xylem rays. A 
study of the secondary phloem has already been made in Exercise XI.

4. The stem of monocotyledons. The stem in many member's of this group is characterized by the fact that the stele consists of collateral bundles which are more or less scattered through the axis, i.e., they are not arranged in the form of a singte "ring" as in dicotyledons. As a consequence, the limits of cortex, pericycle and pith are usually impossible to determine with exactness. However, the recent work of Stover (1934) clearly shows that the disposition of vascular bundles in the stems of grasses does not conform to a single type. Indeed, some genera (Lecrzia, Agropyron) possess a single series of bundles arranged in a cylinder between the cortex and pith. In most monocotyledonous stems, cambial activity is restigial or usually absent from the rascular bundles which are thus wholly primary in structure. Such bundles are often termed "closed" bundles in contrast to the "open" bundles of dicotyledons which possess secondary growth.

Obtain a transverse section of a corn stem and note under low power the characteristic arrangement of the collateral vascular bundles which are more numerous near the periphery of the stem than in the center. Study one of the large bundles under high power, noting that the phloem (composed of sieve-tubes and companion cells) is directed towards the periphery of the stem while the $x y l \mathrm{~cm}$ is nearest the center of the stem. The xylem consists of four large primary xylem vessels (which are arranged like the eyes, nose and mouth of a face) and a number of smaller tracheae: a prominent air-lacuna is usually present at the inner edge of the innermost large ressel. The bundle is more or less completely surrounded by fibers, a feature very commonly found in the bundles of monocotyledonous stems.

5. The vine type of stem in dicotyledons. This type of stem often has its vascular system in the form of a "ring" of bundles which are separated from each other by broad medullary rays composed of parenchyma cells. These radially directed sheets of parenchyma cells may extend vertically the length of an internode or more and in many cases continue to grow (by means of an interfascicular cambium) at the same rate as the fascicular cambium which is increasing the size of the vascular bundles. 
Obtain a transverse section of a one-year-old stem of the "Dutchman's Pipe" (Aristolochia) and examine it under low power. The following tissues and regions can be seen in progressing from the edge of the section to its center, viz.

(a) 1 trpical uniseriate epidermis composed of rather densely protoplasmic cells. Note the extremely thick cuticle which covers the epidermis.

(b) Internal to the epidermis occurs the cortex, formed of an outer zone of rather thin-walled "angular" collenchyma. cells and an inner zone of large "isodiametric", purenchymu cells; note the presence of large druses in many of the parenchyma cells of the cortex.

(c) The stcle is sharply delimited by a broad cylinder of closely joined pericyclic fibers, the secondary walls of which are still increasing in thickness. Internal to the pericyclic fibers occurs the parenchyma of the pericycle which is quite similar in general structure to the cortical parenchyma.

(d) The ruscular system of the stele consists of a ring of typical collutcral bundles in each of which the clearly distinct phloem and xylem is separated hy a cambial zone (the fascicular cambium). Notice that an interfascicular cumbium has arisen as the result of the tangential division of certain of the parenchyma rells of the broad medullury rays which separate the bundles.

The pith of the stem is large and is composed of "isodiametric" parenchyma cells in many of which druses are evident.

Next obtain a transverse section of a two- or three-year-old stem and notice the profound changes in structure which have been occasioned by secondary growth, viz.:

(a) A discontinuous and rather thick laver of phellem. (cork) has appeared as the result of the activity of the phellogen laycr. Notice particularly how the epidermis has been forcibly broken away from the cortex; strips of epiclermal tissue are visible on the outer surface of the corky tissue. A eomparatively extensive development of phelloderm can also be seen intermal to the phellogen. Lenticels are well-developed at certain points.

(b) The previously continuous cylinder of collenchyma has been broken as the result of the pressure of secondary growth. 
Notice that parenchyma cells of the cortex have intruded into the araps between the strips of collenchyma cells.

(c) The previously contimuous cylinder of pricyclir fibers has likewise been ruptured and the gaps filled up by the parenchyma cells from the cortex. Notice the beginnings of wallthickness and lignification in some of the parenchyma cells between the strips of fiber's; these parenchyma cells will finally become thick-walled stome-cells (by a process of secondary selerosis) and will thus effectively "repair" the broken mechanical cylinder. (For further details of this phenomenon. cf the Introduction of Exercise VIII.)

(d) The merlullary roys between the vasenlar hundles have become broad and long and their component parenchyma cells are arranged in more or less definite rudial rows as the result of the continued activity of the intrefascicular cambinm.

(c) Each rascular bumlle has increased enormonsly in size as the result of the continned aetivity of the fuscicular cambium. Notice the arushed condition of the cells in the onter portion of the phloem: this has resulted from the centrifugal development of additional secondary phloem. The xylem portion of each vasenlar bundle shows three definite ammul rings: notice that the largest vessels occur at the edge (i.e., in the "spling wood") of each ammual ring.

(f) The irregnlarly-shaped pith is now much reduced in extent and shows clear indieations of crushing. Aristolochio represents one of the exreptional asses where the pith is actually compressed as the result of secomdary growth.

\section{Suggested Drawings and Notes.-}

1. Prepare a larede diagrammatic drawing of the trans-seetion of the stem of Pelargoninm indicating by legends ol by labels the position and relative extent of all the tissues and regions.

2. Prepare a drawing similar to the above of the trans-section of the stem of Tilia.

3. Draw a lenticel (of Sumbucus, or Aristolochin) as seen in median longi-sectional view showing arefully the eomplementary tissue and the closing layors and the relation of these tissues to the adjacent periderm of the stem. Label all important strurtures. 
4. Prepare enlarged drawings of the periderm of the stem of P'clargoninm. Tilia or sambucus showing the arrangement and structure of the cells of the phellem, phellogen and phelloderm. Examine macerated bottle-cork (i.e. the phellem of the cork oak, Querens subcr) and sketch several of the individual cells.

5. Draw in detail the resin canals as seen in trans-sections of the stem of Pinus.

6. Show, by a diagram, the arrangement of the vascular bundles as seen in the trans-section of the coln stem. Draw in detail a single vascular bundle showing the fibrous bundle-sheath and the structure of the primary phloem and primary xylem.

7. Prepare diagrams of the trans-sections of the stem of Aristolochia. These diagrams should illustrate the effects of secondary growth on the primary structure of the stem.

8. Examine the demonstrations of various types of nodal anatomy and prepare diagrams to illustrate them.

9. Ontline the processes of mitosis and eytokinesis as they occur in the fusiform initials of the cambium in symmosperms (cf. Bailey 1920 and 1929).

10. Outline the methods of secondary growth in the stem of woody monocotyledons (cf. Chamberlain 1921 and Cheadle 1937).

\section{REFERENCES}

1. Arber. A., The Interpretation of Leaf and Root in the Angiosperms. Biol. Rev. $16: 81-105.1941$.

2. Bailer, I. IV., The Cambium and Its Derivative Tissues, III. A recomnaissance of ertological phenomena in the cambium. Amer. .lour. Bot. $7: 417-434.1920$.

3. - — , The eambium and Its Derivative Tissues, IV. The increase in girth of the cambium. Ibil. 10:499509.1923.

4. Barthehmess, A. Vieber den Zusammenhang zwischen Blattstellung und Stelenban unter besonderer Berïchsichtigmng der Koniferen. Bot. Arehiv. $37: 207-260$. 1935.

万. Boke, X. II.. II istogenesis and Morphology of the Phyllode in ('ertain Species of Acacia. Amer. Jomr. Bot. 27:73:90. 1940.

6. Boke. X. II. Zonation in the shoot apices of Trichocerens.s spachianus and Opuntia cyliudica. Amer. Jour. Bot. 28:656664. 1941. 
7. Cheadle, V. I., Secondary Growth by Means of a Thickening Ring in Certain Monocotyledons. Bot. Gaz. 98 :535-5.5. 1937.

8. Chamberlain, C. J., Growth Rings in a Monocotyl. Bot. Gaz. $72: 293-304.1921$.

9. De Bary, Ch. XIV, XV.

10. Eames, A. J., The Vascular Anatomy of the Flower with Refutation of the Theory of Carpel Polymorphism. Amer. Jour. Bot. 18:147-188. $19: 31$.

11. Eames and MaeDaniels, Chs. V', VI, IX, XI.

12. Exau, K., Hilgardia, Ontogeny and Structure of the Pluloem of 'Tobaceo. Ibid., $11: 343-42+.1938$.

13. - Phloem Anatomy of 'Tobaceso Affected with ('urly Top and Mosaic. IIlgardia 13:4:37-490. 1941.

14. Foster, A. S., Problems of Strueture, Growth and Evolution in the Shoot Apex of Seed Plants. Bot. Rev.5:454-470. 1939.

15. Grégoire, V., La morphogénèse et l'autonomie morphologique de l'appareil floral. La Cellule $47: 287-4.52 .1938$.

16. Ilayward, ('h. IHI.

17. Ilehn, J., Untersuchungen ǔber die Differenzierunar del sprossscheitelmeristeme von Dicotylen unter besonderer Berüchsichtigung des Proeambiums. Planta 15:10j-191. 1932.

18. Jeffrer, Ch. XIII.

19. Kaplan, R., Ueber die Bildung der Stele ans dem Trmeristem von Pteridophyten und Spermatophyten. Planta $27: 22+2068$. 1937.

20. Kïster, E., Sekundäres Dickenwachstum; Holz und Rinde. Allgememe Einletung. Handbueh d. Pflanzenanatomie. IX. Berlin. 1939.

21. Louis, J., L'ontogénèse du système eonducteur dans la pousse feuillée des Dicotylées et des (ivmmospermes. La c'ellule 44 : 87-172. 1935.

2.2. Smith, G. M., Cryptogamic Botany. Vol. ll. ('h. V. New York. 19838.

2:3. Sperlich, A., Das trophische Parenchym. B. Excretionscewebe. Ilandb. d. Pflanzenanatomie. IV. Berlin. 1939.

24 Stover, E. L., Development and Differentiation of Tissues in the Stem 'Tips of (trasses. Ohio .Jour. Sei. 3t:150-160. 1934.

25. Wilson, C. L. and Just, 'T., The Morphology of the Flower. Bot. Rev. $5: 97-131$. 1939. 


\section{Exercise XII}

\section{THE LEAF}

I. Introduction.-As stated in the previous exercise, it is difficult, on both theoretical as well as practical grounds, to demarcate rigidly the leaf from the stem. If, as. several morphologists have suggested, the "leares" of higher plants arose phylogenetically from cleterminate branch systems, this difficulty at once becomes understandable. Indeed, perhaps the most useful character which distinguishes the leaf from the stem, apart from its origin at the shoot apex, is the early cessation of apical growth. The leaves of ferns retain an apical meristem for a relatively long period in their development, but in seed plants the final size and form of the leaf is largely determined by interealary growth. Leaves are without much question the most diversified of all the "organs" produced by higher tracheophytes (ef. Troll 19381939, and Arber 1941). The foliage leaf, which is the most familiar type, varies from the small seale-like structures found in certain gymmosperms and angiosperms to the enormous and complex leaves of palms. In addition to foliage leaves, other types of foliar organs must be considered under the morphological concept of "leaf." As illustrations may be mentioned cotyledons, bud scales, bracts, and aceording to classical theory, the appendages of the flower. In view of such morphological and functional diversity, it is obvionsly impossible to generalize with respect to the histological structure of "leaves." From an anatomical standpoint, the leaf may be regarded as an "expansion" of the axis in which all the fundamental primary tissue regions (i.e., epidermis, cortex and stele) may be recognized. But the arrangement and structure of the photosynthetic parenchyma (i.e.. the mesophyll), the vascular system (i.e., the ma.jor and minor veins) and the mechanical tissues (e.g.. collenchyma, sclereides and fibers) vary within extremely wide limits. 
In this exercise, a brief study will be made of a few representative leaf types, with particular emphasis mon the anatomy of the leaf-blate or lamina. It is beyond the soope of this hook to discuss the process of leaf origin and the differentiation of the varions leaf tissues in seed plants. For information on these matters, referenere should be made to Foster (1936). Hayward (Ch. III, pl). 77-8.i), Troll (19:38), and ('ross (1940, 1941).

\section{Material for the Study of Leaf Anatomy.-}

1. The laminu of the foliage leaf of litue (syringa vulgaris). Ohtain a stained trans-section of the lamina and study its histology under low magnification. Note first of all the clear distinction letween the mirlrib and the two thin lateral flaps of tissue. An examination of the midrib reveals a large collaterel vasculu buntle in whieh the phoem is direeted towards the abarial or lower leaf-surface while the xylem is sitnated beneatlo the ardurial or uper leaf surface. With this orientation in mind, it will now be elear that the lamina exhibits a trpieal dorsiventrul cherecter. shown not only by the relative positions of xylem and phloem in the larger veins but also by the differentiation of the mesophyl?, into pelisede and spongy penenchyma. Since the anatomy of the lamina in the region of the veins differs somewhat from the interveinal areas, it will be more convenient to describe briefly the varions tissues and then to point out their topographical variations. In the lamina of this leaf, three principal tissues are present, viz.:

(a) The epirtermis. The adtuxinl epillermis eonsists of somewhat oval cells, the onter walls of which are eovered hy a thin cutiele. Nlthough exact measurements are lacking, there seems to be relatively little difference in the thickness of the imner. onter and radial walls of the epidemis. Obselve that many of the epidermal cells possess a protoplast which is peripheral in position. Stomate are not meommon in the adaxial epidermis. Note particularly the relatively small size of the ward "ells and the an chamber present beneath arch stomate. Trichomes. represented by eapitate and simple hairs, oceasionally develop but these struetures are more abundant on the abaxial surface of the lamina. The aborial eprdermis is fumdamentally similar to the adaxial epidermis exeept that the eells are somewhat smaller and thinner- 
walled. Stomata are more abundant in this layer of the lamina, a conmon situation in many angiosperms. "Stalked" stomata are frequently present in the midrib region. Multicellular capitate hairs, lying within shallow depressions, are relatively common and consist of a terminal group of densely protoplasmic scerctory cells (with rather thick outer walls) which are seated upon a small unicellular stalk. Haberlanclt (p. 204) suggests that the capitate hairs of syringa may absorb thin films of water from the leaf surface but this supposed function requires further inrestigation.

(b) The mesophyll. This tissue region is composed of two types of parenchyma, viz.: (1) the palisale parenchymu which is found directly beneath the adaxial epidermis and consists of rather narrow, thin-walled, somewhat "rectangular" cells, the long axes of which are perpendicular to the epidermis. Notice that interecllular air spaces are prominently developed in the palisade parenchyma. In addition to a prominent nucleus, each palisade parenchyma cell contains a large number of peripheral rhloroplusts in which the process of photosynthesis is carried on. Directly internal to the abaxial epidermis occur's (2) the spong! parenchyma which is composed of thin-walled irregular cells which have no definite orientation and are very loosely arranged. Notice that in many instances adjacent cells of the spongy parenchyma touch each other at their narrowest points so that the maximum of wall surface borders upon the large air spaces. The cells contain a peripheral protoplast and a smaller number of chloroplasts than occur's in the cells of the palisade parenchyma. The spongy parenchyma has at least two important functions. First, because of its loosely arranged cells, it acts as a "ventilating tissue" of the leaf, i.e., liffusion of CO.. water vapor and $O_{2}$ between the air lacmae and the cells can take place with relative ease. Second, the spongy parenchyma carries on some photosyuthesis althongh this function is more efficiently performed by the palisade parenchyma. Areording to Haberlandt (p. 287) no trans-location takes place from one palisade-cell to another but "the stream of syuthetic products" follows the long ares of these nements. Some anatomical erirlence in smpont of this view is furnished by the fact that small groups of $2-10$ palisade cells in 
certain plants converge at their lower ends and rest upon the upper dilated end of a cell of the spongy parenchyma. Haberlandt regards these specialized cells of the spongy parenehyma as collecting cells which receive the products of photosynthesis from the palisade cells and transmit them directly or indireetly to the main vascular channels.

(c) The vascular system. Investigate first of all the general structure of the midrib, and note particularly the ahsence of photosynthetic parenehyma from this portion of the blade. Instead of the ustal spongy and palisade parenchyma, the median vaseular bundle is covered on both sides by a number of lavers of isodiametric thick-walled cells, the outermost of which are thickened in such a manner as to resemble collenchyma. (Note: This "replacement" of photosynthetic parenchyma by collenchyma and thick-walled parenchyma occurs to a less extent in connction with the smaller vascular bundles of the blade. In other types of leaves selerenehyma may be present-mechanically. a "girder effect" is produced.) Several smaller vascular bundles with the phloem towards the adaxial surface are usually seen in the upper part of the midrib; these "accessor!l bundles" mite basally with the single leaf trace. A certain amount of secondm? growth has taken place in the median vascular bundle, a phenomenon which is of rather general oceurrence in the larger veins of dicotyledonons leaves. The eonspicuous sccondary xylem is composed of conducting elements (probably both tracheids and ressels) and fibers arranged in more or less definite radial rows and uniseriate $x y l c m$ rays which extend across the "eambial zone" into the phlocm. The primary rylem (which lies abore the secondary xylem) consists of eells which show more or less of a radial arrangement and which are imbedded among xylem paranchyma. The scrondary phloem consists of polyonal thin-walled sieve-tubes which are associated with small somewhat triangular densely protoplasmie companion cells, phloem parenchyma, and uniseriate phloem rays, each of which frequently terminates in a large parenchyma eell. The primary phloem is indefinite and diffienlt to distinguish. The "combial zone" "an be distinguished but is not nearly as prominent or distinet as in the ease of a stem. Nevertheless, three or more radial rows of differentiating cells 
can be rather clearly seen. In gencral, cambial activity is never prolonged in the veins of most leaves. In the smaller veins of the lamina, the rascular tissue is consiclerably reduced in amount and secondary growth may be entirely lacking. In certain regions of the blade, the diverging bundles may be cut more or less obliquely so that the characteristic type of primary xylem elements may be recognized. The very small leaf veins may consist of several parenchyma cells and a few primary xylem elements; a bundle of this character is usually surrounded by a jacket of parenchrma cells containing chloroplasts (i.e., the so-called " $b$ or(ler parenchyma"').

2. The leaf blade of com (Zea Mays). Obtain a transverse section of a corn leaf and examine it under low power. The adaxial epidermis is readily identified by the presence of groups (3-5) cells) of somewhat lens-shaped, apparently empty cells. These cells are known as bulliform cells and by changes in their turgor allow the leaf-blade to curl or uncurl, a phenomenon which may be advantageous in restricting the loss of water from the leaf moler arid conditions. The typical epidermal cells of both the abaxial and adaxial epidermis are somewhat oval in transverse section (actually they are rather elongated cells) and are provided with a definite cuticle. Stomata, with conspicuous air-chambers beneath them, are present in both epidermal layers. Occasional unicellular, sharp-pointed hairs occur on the adaxial epidermis.

The mesophyll tissue of the leaf shows no clear differentiation into palisade and spongy parenchyma but instead is composed of several layers of rather compact parenchyma cells.

The vascular system of the leaf consists of a parallel series of collatcral bundles. The majority of the bundles are rather small; at intervals, fairly large bundles occur. Examining one of the small bundles under high power, note that it is completely surrounded by a bundle sheath of rather large "isodiametric" parenchyma cells which contain chloroplasts; the bundle sheath, sometimes termed the "mestome sheath," may act as a conducting layer which presumably transports the prodncts of photosynthesis directly to the vascular system, i.e., the phloem. The xylem of each bundle is directed towards the adaxial surface of the leaf and consists only of small tracheae. The phloem of the bundle 
is nearest the abaxial surface of the leaf and at most is formed of a few small sicuctubes and componion cells: in rery small bundles, the phloen may be represented by parenchyma cells. The structure of a large cuscular bundle in the leaf is quite similar to the anatomy of a stem bundle (cf. Exercise XII). Notice particularly the clear distinction between the sieve-tubes and companion cells of the phloem and the presence of an air laema at the adaxial edge of the xylem. Fibcrs are present on both edges of the bundle and may even partially surronud it ; notice the thick-walled character of the epidermal eells direetly adjacent to the fiber's. This arrangement of fibers on either side of the vaseular hundle is quite characteristie of grass leaves and is regarded as a rery efficient "plan" for" securing mechanieal strength in the leaf.

3. The bud seule. In general, bud seales are distinguished anatomically from foliage leares by (1) their greatly reduced rascular system, which mar consist of a series of parallel or dichotomizing reins, and (2) hy a simple trpe of molifferentiated mesophyll. The outer hud scales of eertain trees may prodnce a well-developed peridrm heneath the onter epidermis (e.g.. desculus). Mechanical cells, such as fibers and sclereidrs, are often prominent for example in Cumellia, Fugus, Quereus, and Populus. (For further details, consult Foster, 1928, pr. 1371+6.) Study prepared trans-sections of the bud scales of sevelal of the forms listed above.

4. The leques of gymmosperms. Examine stained trans-sertions of the needles of I'imus noting especially the smuken stomata. the invaginated walls of the mesophyll eells and the vascular bundle (in some species two bumbles are present) embedted in Mansfusion tissur. (('f. Eames and MacDaniels. pp. :307-308.) For comparison, study trans-sections of the fan-shaped lamina of the foliage leaf of Ginligo bitobu. (A discussion of the histology of this leaf is given by (hamberlain, 1935). pp. 191-193, and Fig. 210. p. 196.)

\section{Suggested Drawings and Notes.-}

1. Prepare a diagrammatic drawing of the trans-section of the lilace leaf, indicating the position and extent of all important 
tissnes. 1)raw, showing cellular detail, a narow sector through the thin portion of the blade. This drawing should include a vein. Label all ceells and important structures.

2. Draw in detail the cellular structure of a small sector through the eorn leat. This drawing should include a group of bulliform cells and at least one vell-developed vein.

3. Prepare diagrams to illustrate the structure and the arrangement of tissues in the bud scale of some angiosperm and in the foliage leaves of Pims.

4. Ontline the differentiation of a "typical" dieotyledonous leaf, such as Ticotiana or Pclargomimm (cf. Foster, 1936).

5. Explain what is meant by the expressions "sum leaves" and "sliade leaves." (Cf. IIaberlandt, Pl. 295-297.)

\section{REFERENC'ES}

1. Arber, $\Lambda$.. The Interpretation of Leaf and Root in the Angiosperms. liol. Rev. $16: 81-105.1941$.

2. Chamberlain, C. .J., Grmmosperms, Strueture and Evolution. Chicago, 19:3-.

:). Cross, G. L. Development of the foliage leaves of Taxodimm distichm. Amer. Jour. Bot. 27:471-482. 1940.

4. Some histogenetic features of the shoot of Cryptomeria japomicu. Amer. Jomr. Bot. 28:57:3-58:. 1941.

5. Eames and IIacDaniels, C'h. XII.

6. Foster, A. S., Salient Features of the Problem of Bud-seale Morpliology. Biol. Rev. 3:12:3-164. 19:2

7. — Leaf Differentiation in Angionerms. Bot. Rev. $2: 349-372.1986$.

8. Ilaberlandt, C'h. VI.

9. Nlaywared. ('h. III, pl). 75-87.

10. Jeffirey, (1h. XIV.

11. Meyer, F. .J., Das trophische Parencluym. A. Asiminationsgewebe. IIandb. d. P'flanzenanatomie. IV'. Lerlin, 192:3.

12. Pfeiffer, II. Die pflanzlithen Trennumgsewebe. Ilandb. d. Pflanzenamatomie. $\mathrm{Y}$. 1920.

13. Troll, W.. Veroleidhende Morphologie der höheren Pflanzen. Bd. I. Zweiter Teil. 1-4. Lieferumg. (Morphologie des Blattes) Berlin, 1938-39. 


\section{Exercise XIV}

\section{TIIE ROO'T}

I. Introduction.-Except in the Psilotales, Salvinia and a few specialized parasitic forms, roots are a typical feature of the sporophyte of vascular plants. In many of the lower tracheophytes, the primary root is short-lived and numerons adventitious roots soon begin development from various portions of the shoot system. In seed plants, however, the radicle often reaches great prominence and in such cases is termed a tup root. Additional fibrous roots in seed plants arise by successive branchings begimning with the first root but are also commonly formed adventitiously from the stem. Roots perform a number of important physiological functions. Primarily, they serve as organs which absorb water and solutes from the soil solution. In addition, they are very important as structures which anchor the plant firmly in the soil. The storage of reserve food material also occurs in most roots to some extent and is very obviously displared in the fleshy "roots" of carrot, beet. turnip and similar econonic plants. Although the usual enviromment of roots is the soil, acrial roots are produced in certain vines which serve to attach the shoot firmly to the surface npon which it may be growing.

1. Origin and structure of the mimary tissues of the root. The primary structure of the root differs from that of the stem in a number of respects. The following brief resmme of these differences will emphasize the salient histological chalacteristics of the root, viz. :

(a) The structure and grouth of the root aper. In marked contrast to the superficiul position of the teminal meristem of the shoot, the root apex consists extermally of a root cop which acts as a protective huffer to the deliale meristem beneath it. $A$ wide variety of "types" of apical structure have heen deseribed 
for the roots of various seed plants (ct. Hayward, pp. 44-47), but it is evident that this region of the root deserves further intensive study with the aid of modern botanical microtechnique (cf. von Guttenber's, 1940, 1941). The essential point here is that the activity of the terminal meristem of the root is fundamentally different from that of the shoot apex. In the latter, exogenous leaf primordia arise from the flanks or base of the apex. But in the root, two dissimilar patterns of differentiation originate from the terminal meristem, one leading to the outward addition of new cells to the root cap, the other contributing new cells to the main but unsegmented body of the root. These differences are at present impossible to explain but it is evident that they determine the fundamental morphological differences between root and shoot (cf. Arber, 1941).

(b) Primary tissue regions. Young roots, prior to secondary growth, resemble stems in the presence of epidermal, cortical and stelar regions. The epidermis of roots is nsually devoid of a cuticle and stomata and its chief rôlc appears to be that of absorption, a process which is farored by the development, behind the region of elongation, of a zone of root hairs. The cortex of roots is often entirely composed of thin-walled storage parenehyma and is soon destroyed if secondary growth oceurs. Apparently the endodermis, which is commonly regarded as the innermost layer of the cortex, is a consistent feature of roots, in contrast to its variable distribution in the stem. But without doubt one of the most fundamental characteristics of the young root is shown by the arrangement and development of the primary vascular tissnes of the stele. In striking contrast to the collateral position of xylem and phloem in the siphonostele of typical stems. these tissnes are arranged in a radial and alternate pattern in the root. Thus, in the anatomical sense, there are no true primary vascular bundles in the stele of the root. As seen in trans-sectional view, the primary xylem and phloem of the root appear as separate and altermating strands of tissme. Very frequently, the xylcm "plates" as they are often termed, meet in the center" to form a solid core. In many roots, however, particularly in monocotyledons, the center of the stele is occupied by a core of 
parenchyma which resembles the pith region of the stem. Although the number of phloem and xylem groups in a given root is equal, variations oceur between the roots of the same plant as well as between different species (c.f. Esau, 1941, p. 4.2. T'able 1). There appears to be no satisfactory explanation for the inconstancy in the number of phloem and xylem strands so characteristie of the roots of some angiosperms. Depending upon the number of primary xylem groups, the stele is described as dimen (2), triarch (3), tetrarch (4), pontarch (5), ete. The stele in monoeotỵledons ustally consists of many alternating xylem and phloem groups and hence is designated as polyarch.

In further contrast to the stem of seed plants, the primary xylem of the root is cxurch. This means that the radial maturation of the tracheary elements from provaseular tissne oceurs in the centripetal direction. Ience the motoxylem lies at the ontermost edge of each xylem strand, next to the prricyclc, while the mcturylem is situated towards the eenter of the stele. Since exarch primary xylem is only fomd in the stens of the lower vas"ular plants (e.g.., the Psilopsida and Lycopsida), the root of seed plants has been regarded by some anatomists as a "conservative" or "primitive" organ (cf. Jeffrey, Ch. Xll). Much work needs to be done on the comparative histogenesis of the primary tissues in the root. In several recent studies, Esan (1940, 1941) has made important contributions to our knowledge in this direction. It is interesting to note that her observations indieate that the phloem begins to differentiate nearer the apieal meristem than does the xylen. In the protophlorm of earrot, for example. "the sievetubes complete their differentiation about 300 microns from the apex of the root" whereas the first protoxylem elements "show secondary walls approximately 1 millimeter from the root apex, but do not lose their protoplasts thromen another millimeter of the root."

(c) Origin of lateral roots. Branching of the stem normally originates from lateral buds which develop at or near the shoot apex from superficial cells or eell layers. In marked contrast. the bronching of the root is strictly sudogrmons. The origin of lateral root primordia usually oreurs through the renewed growth and division of certain eells in the pericycte of the stele distal to 
the zone of root hairs. Aceording to Hayward (1). 51), in sonte plants the adjacent cells of the endodermis may contribute to the formation of the lateral root prinordium. Armok (1940) laas shown that in the water hyacinth (Eichhormia crassipes) lateral roots arise in the "immature pericgrele" and "at the forwal end of the region of elongation." Jiecanse of its internal origin, the further development of the lateral root involves its penetration through the endodermis, cortex and epidermis of the mother mot to the ontside. Just low this ocems is not entirely clear. The suggestion has been made that the mechanical pressure exerterl by the emerging lateral root may also be accompanied by some kind of ehemical dissolution of the tissues interposed in its path. In roots with three or more xylem plates, lateral root primordia typically appear opposite each of the protoxylem points. Consecunently, muless injuries or abnormalities occur, the lateral roots tend to emerce in vertical rows which are equal in number to the xylem groups. But in diarh steles, lateral roots may appear at each side of the two phloem groups. In this case there would be forr reltical rows of lateral roots (ef. Esau, 1940, pr). 190-194).

2. Secomdary growth in roots. The roots of many herbaceous dicotyledons and of all woody plants exhibit secondary growth in thickness. However, because of the radial, alternate arrangement of the primary vascular tissues, the combium first appears as separate bands of periclinally-dividing cells which oriquate from parenchyma cells internal to each phloem group. At these points formation of secondary phloem ontwardly and secondly xylcm inwardly, oceurs as in a typical stenl. In woorly plants, the originally separate strips of cambinm finally become united laterally as a result of tangential divisions in the pericrele external to each xylem group. Thus at an early stage, the vascular cambinm in this type appears lobed in trans-section. Tltimately by the formation of secondary phloem and xylem external to the xylem plates, the contour of the cambium becomes cylindrical. In roots of this type, the primary xylcm eventually becones completely smrounded by a cylinder of secondary xylem. In certain herbaceous plents, in contrast, the cambium, at points opposite the protoxylem points, forms broad parenchymatous rays so that a 
dissected type of secondary rascular cylinder results (Jeftrey, pp. 156-157 and Hayward, pp. 48-51). When secondary growth is pronounced in a root, the primary phloem, cortex and epidermis soon become crushed and slough away. In trees, a typical "bark" is produced and, save for the exarch primary xylem in the center, all structural resemblance witl a root is lost. The first periderm layer of the root arises by the formation of a phellogen in the pericyele. Later-formed phellogen layers may subsequently appear, as in the stem, from living cells in the secondary phloem.

\section{Material for the Study of the Root.}

1. The root of buttcreup (Ranunculus sp.). Obtain a stained trans-section of the root and study the following tissues and regions begimning at the edge of the section :

(a) The epidermis, a uniseriate but broken layer of collapsed and partially destroyed cells. The imperfect condition of the epidermis presumably is due to the abrasive effect of the soil on the root. Notice that a more or less disorganized protoplast is visible in some of the epidermal cells.

(b) Within the epictermis occurs the rather broad, homogeneous cortex which is composed entirely of rather thin-walled, "isodiametric" parenchyma cells most of which are separated from one another by prominent intercellular air spaces. Observe that while the onter layers of the cortex are composed of rather tightly joined empty cells (forming a "hyporermis"), the inner eortical cells contain prominent starch grains. Large, somewhat irregular simple pits are visible on the end walls of the cortical parenchyma cells.

(c) The center of the root is oceupied by the stele which is externally separated from the cortex by a miseriate cylinder of eells, the cudodermis. Study the endodernis under high power, noting the presence of a protoplast in many of the cells. The salient featme of the endodernis (in the primary endition) is the presence of a suberized or "utinized band which extends (ompletely about the inner surface of the radial and end walls of each cell. 'These band-like thickenings of the wall are known as Casparian strips and in recent years have received 
a great deal of attention because of the apparent physiological importance of the endodermis as a cellular layer which regulates the entry of water and mineral salts into the vascular system of the stele. The assumption is made that the suberized nature of the Casparian strip renders it impermeable to water so that diffusion must take place throngh the tangential walls and the protoplasts of the endodermal cells, i.e., through a semi-permeable membrane. However, the exact function and significance of the endodermis is in need of much further investigation.

In the endodermis of Ranunculus, the presence of the Casparian strip is indicated by the red color of the short radial walls. Individual cells of the endodermis may have nuiformly and heavily thickened walls, a phenomenon previously recorded by Caspary in the case of Ranunculus Ficaria (cf. De Bary, p. 123). In the roots of certain plants, all of the cells of the endodermis may be thick-walled in character (cf. Eames and MacDaniels, p. 102, Fig. 51). Within the endodermis occurs a single layer of living cells which is known as the pericycle. The most conspicuous portion of the stele is represented by the primary vascular tissue which shows the characteristic radial arrangement of the xylem and phloem goups. It will be seen that four radial plates of xylem (which join in the center of the root, thus forming a protostele) are present; the stele is therefore designated as tetrarch. The protoxylem (which presumably consists of annular and spiral elements) is represented by several very small "polygonal," thick-walled cells found at the outer edge of each xylem plate. The metaxylcm (which probably is composed of pitted elements) consists of much larger cells and as stated previously forms a homogeneous tissue in the center of the root; a pith is thus absent. Laterally adjacent to each xylem plate near its outer edge, you will find one or two rather thick-walled cells, which are approximately hexagonal as seen in transverse section and which appear distinct from the xylem because of their lighter-staining walls and the possession of a more or less disintegrated protoplast. The shape and structure of these cells suggest that they are sieve-tubes; their exact morphology is difficult to interpret but they seem to belong to the phloem. Each of the four phloem groups is separated laterally and internally from 
the xylem by one or more layers of parenchyma. The phloem consists of thin-walled living cells which, as in many plants, are distinguished with difficulty from the surrounding parenchyma.

2. The root of Smilax, Zea or some other monocotyledonou. type. Examine carefully the trans-section, noting partieularly the polyarch stele and the central pith-like region.

3. The origin of lateral roots. Study transverse and longisections of the root of the water hracinth (Eichhormic crassipes) and observe the method of origin and early ontogeny of the lateral root primordia. For eomparative purposes, make a similar study of lateral root development in bean or willow.

4. Sccondary grouth in roots. Study a series of trans-seetions of the root of a woody or herbaceous plant cut at levels successively distal to the region of matmration of the primary vasenlar system. Observe the method of origin of the cambinm and the formation of secondary vascular tissues and the periderm.

\section{Suggested Drawings and Notes.-}

1. Prepare diagrammatic drawings of trans-sections of the root of Ramunculus and of some monoeotyledonous type showing the position and extent of all the primary tissues. Drau in detail a portion of the stele in each trpe to illustrate the structure of the primary phloem and xylen.

2. Prepare diagrams based upon both transverse and longiseetions to illustrate the origin of lateral roots and their emergence to the surface of the mother ront.

3. Prepare a series of diagrams hased upon material studied in the laboratory to illustrate the origin of the eambinm and the effects of seeondary wrowth upon the primary tissues of the root.

\section{IREFERENCES}

1. Arber, $\Lambda$.. The Interpretation of Leaf and Root in the Angiosperms. Biol. Rev. 1(i:81-10.). 1941.

2. Amold. ('. A.. A Note on the Origin of the Lateral Rootlets of Eichhornin crassipes (Mart.) Solms. Amer. Jour. Bot. $27: 728-730 . \quad 1940$.

3. De Bary, pp. 348-366.

4. Eames and MacDaniels, Ch. X 
5. Esau, K., Developmental Anatomy of the Fleshy Storage

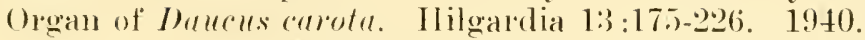

6. - Phloem Anatomy of Tobaceo Affeeted with ('urly Top and Mosaice Ibirl., 1:3:4:37-490. 1941.

7. Ilayward. C'h. II.

8. Jeffirey, ('h. XII.

9. Von Cuttenberg. H. Der primäre Bau der Angiospermenwurzel. Irandl). d. Pflanzenanatomie. VIII. Berlin, 1940.

10. - Der primäre Ban der Gymmospermenwurzel. Ibirl.; Berlin, $19+1$. 



\section{APPENDIX}

The following brief notes on certain phases of microtechnique are given here to facilitate the use of this book by the teacher and student. For full information on the various procedures used in preparing tissue for microscopic study, reference should be made to the publications of Chamberlain (1932), Rawlins (1933), Johansen (1940), and Sass (1940), cited under "General References."

\section{Free-hand Sections}

In many of the exercises in this book, directions are given for the study of sections eut by hand from living stems, leaves or other plant structures. To prepare such material requires only simple technique and in addition provides a realistic picture of cells and tissues which should precede the examination of microtomed and permanently-stained preparations. In the laboratory the student can acquire the necessary skill with a sectioningrazor to enable him to explore the structure of such tissues as the epidermis, parenchyma and collenchyma. Sections ent by hand should be carefully mounted on a clean slide either in distilled water or in the various reagents designated and the cover-glass lowered gently into place. For more resistant cells, such as sclereides or fibers and for the critical study of the sieve-plates in phloem elements, the use of the carbon dioxide freezing microtome is highly desirable. With the aid of this instrument, a large number of thin sections may be prepared by the instructor in advance of class use. The student must learn to check free-hand preparations at frequent intervals so that the sections are not allowed to dry out. Cells immersed in fluid are not only easier to study from an optical point of view but they also retain a more or less normal structure over a relatively long period of observation. Sections of hairy objects, such as many leaves or stems, are often difficult to mount in water without the formation of numerous air-bubbles. This difficulty may be removed by 
mounting such sections in a weak solution of alcohol. This may act as a killing reagent for the protoplasm but it cloes make possible the aecurate study of the shape, arrangement and character of the walls of eells.

\section{l'repared SLIDEs}

The use of permanent slides is essential in the stmuly of many of the topics outlined in this book. This is particularly true for the work to be done under Exercises III, X, XII, XIII, and XIV. Suitable preparations as a basis for elass study are obtainable from commercial supply houses or may be prepared for the student directly. With reference to the latter possibility, detailed suggestions for the eollection, fixation, sectioning, and staining of tissues and organs are presented srstematically in the recent manuals on microtechnique by .Johansen (1940) and Sass (1940).

\section{Maceraten Tissite}

One of the most important skills which the student must develop in laboratory practice is the ability to vismalize eells as three-dimensional bodies. This is often extremely difficult on the basis of the examination of sections which tend to create a twodimensional concept. Furthermore, many definitive features of cells, particularly the strueture and arrangement of pits and fibrous thickenings in tracheary elements, and the chararter of perforations in ressel elements. can best be studied in isolated reells. For these reasons, a study of macerated tissue is recommented for many topios in this book and is especially desirable in connection with Exercises II, VIII, IX, and X. The maceration of plant tissme is most effectively aecomplished by the use of certain reagents which dissolve the intercellular substance and thus carme the separation of a piece of tissme into its component cells. Jeffrey's methort is usually satisfactory. Small pieces of the material, no thicker than a match, are placed in a ondas vial containing a mixtme of equal parts of $10 \%$ rloromice acid and $10 \%$ nitrie acisl. The vial is then ronked and placerl in an electric oven at a temperature of $: 30^{\circ}-40^{\circ}$ C. until the material becomes soft or "mushy" in textme. Ilard material, such a. 
wood and the shells of nuts may require sevcral days in the oven, during which time it is alvisable to change the macerating fluid once or twice. Boiling small slivers of wood before placing them in the acids drives ont the air and accelerates the maceration process. The macerated tissue is carefully washed in distilled water to remove as much of the acid as possible and can then be transferred to $50 \%$ alcohol for future study. Often effective lesults may be secured by staining the isolated cells in safranin. For class use, it is only necessary to agitate the alcoholic suspension of cells and to add a drop with a pipette to a slide in order to secure a fairly representative "sample" of the desired cell types. Permanent preparations of macerated tissue are easily made by placing small quantities of cells in water on a slide, evaporating the excess water on an electric hot-plate and momnting in glycerine-jelly. Circular cover-glasses should be used, the edges of which can be sealed with some type of cement which prevents drying out and the entrance of air.

\section{Spectal, Reanents}

1. Phloroglucin and Hydrochloric Acid.-The addition of these reagents prodinces a red color in the walls of sclereides. lignified fibers and tracheary elements (cf. Exercises VIII, IX, and $\mathrm{X}$ ). The stain is not permanent but nevertheless is extremely useful in demareating the thick walls of certain types of cells. A saturated solution of phloroglucinol should be prepared in $9.5 \%$ alcohol. Mount the section or tissue fragment directly in a drop of this reagent on the slide and add a cover slip. Then introduce a drop of concentrated hydrochloric acid at the edge of the cover slip. Great care should be taken to earry out this procedure some distance away from the microseope.

2. Potassium Iodide (IKI) and Sulphuric Acid.-This is a specific test for cellulose. Mount the sections in the potassium iodide (1 gr. iodine and $3 \mathrm{~g}$. potassium iodide in $300 \mathrm{cc}$. of distilled water, according to Rawlins, 1933) and add a cover slip. The introduction of a drop of $65 \%$ sulphuric acid will cause cellulose walls to turn blue in colol. 
3. Aniline Blue.-This is a specific stain for callus depositions on sieve-plates and is essential for the procedure outlined in Exereise XI. Sections should be immersed for a short time in a $.1 \%$ aqueous solution, and then transferred, after gentle washing, to a drop of water. The callus on the sieve-plates is stained blue. Dr. A. S. Crafts has suggested to the writer the following improvement: Place the sections in IKI, wash in water, stain in aniline blue for about five minutes, then wash briefly again with IKI and mount for study in tap water or glycerine.

4. Neutral Red.-This vital stain is very useful in staining the vacnome of plant cells and is recommended for use in Exercises $\mathrm{V}, \mathrm{VI}$, and VII. Mount the sections directly in a $.1 \%$ aqueous solution.

5. Sudan IV.-This reagent is specific for the cuticle, and for cutinized and suberized cell walls. Place the sections in a drop of alcoholic solution of Sudan IV (.5 g. in $100 \mathrm{cc}$. of $80 \%$ alcohol) on a slide and warm gently over an alcohol flame. Add a coverglass and examine under the microscope. The cuticle, as well as waxy materials present in walk are stained red. This reagent is very desirable for use with Exercise $V$. 


\section{INDEX}

ABIES, strueture of shoot apex, 25

Aceessory vascular bundles, in leaf of Syringu, 126

Acsculus, aolleter's on bud seales of, 54

Albuminous reells, of grmmospermous phloem, 94

Allinm, study of epirtermis of $48-49$

Amyloplasts, in eells of storage organs, 4

Aniline blue, stain for callus, $! \vec{\imath}$, 142

Anisotropic, use of term, ?

Anmual ring, structure of, 115

Ammular clements of protoxylem, 84

Anthorganin pigments, in vaenome of cells, 3

Apex (see shoot apex, root apex, apical meristems)

Apical cell, highly vacuolated character of, 20

meristems, 21-27

Appendix, 139-142

Apposition, methorl of wall-thickening, 9

Aristolochiu, sturly of stem of, $119-120$

Astrosclereides, in fruit of Carmu and Juglans, 70-i1

in leaf of Camellia, 71

strueture and occurrence of, 68 A renu, origin of leaf in, 24

BARK, general composition of, $10 T$
Bars of Sanio (sec Crassulae), 13,89

Basswoorl, bast fiber's of, $77-78$, 113

cell walls in pith and eortex, 11 sturly of stem of, 111-117

Bast fibers, of Tilia, 11, 77-78, 113 wall structure in Tiliu, 11

Bein, macrosclereides in testa of, 71

primary xylem in hypocotyl of, 87,88

Begoniu, photosynthetic parenehyma of, 59-60

Betu, vessel development in, 84

Betulu, ressel elements of, 89

Bicollateral vascular bundle, in stem of Cucurbita. 98

Birch, vessel elements of, 89

Black locust, ontogeny of vessels in, $83-84$

Blind pit, use of term, 11

Boekmeria, bast fibers in, 75

fiber elongation in, 76

Bordered pits, of tracheids, 82 pit-pairs, in tracheirs of Pimus. $13,88-89$

study of, 13

Bratchyselereides, in fruit of $P y-$ rus, 70

structure and oreurrence of, 68 Bracken fern, primary xylem tracheae of, 88

Branch gaps, use of term, 102 Branch traces, use of term, 102 Bud scale, anatomical eharacteristies of, 128

stmely of anatomy of, 128 
Bulliform cells, in leaf epidermis of $Z e a, 127$

Buttereup, study of root of, 134 136

CALAMOTILFA, ontogeny of tracheae in, 85

Calcium oxalate, in erystals, 4-5

Callus, definitive, 97

cylinder's, in sieve-plates, 97

Calyptrogen, produces root cap, 26

Cambial aetivity, effects on primary tissues, 106-107

initials, $27-28,106$

wall, use of term, 9-10

zone, use of term, 106

Cambium (see also vascular or cork cambium)

characteristics of, S6-S7

origin and activity of in roots, 133-134

Comellits, astrosclereides in leaf of, 71

Carrot, chromoplasts of, 3

Curyt, astroselereides of, $T(1-T 1$

Casparian strips, of endorlermis of root, 134-1.35

Cedrus. strueture of shoot apex. 25

Celery, structure and ontogeny of eollenehyrua, 63-64

vessel development in, $8+$

Cell, application of term, ?

ergatic suhstanees in, +6

Hooke's nse of term, 1

modern use of term, 1

plastids of, 3

protoplast of , 1-6

plate, relation to interecellular layer, 9

sal), in hail cells, 2

theory, 1

types, tabulated summary of. 40- 13
Cell wall, absence in certain cells, 7

criteria for layer's of, 9 gross layers of, 8-11

in sieve-tube elements, 97-98

reversible changes in, 10

use in classifying cell types, $T$

C'ellulose, in seconclary wall, 10, 75

Chloroplasts, in guared cells, 47

in leaf cells of Eloden, 3

in mesopliyll of leaf, 125

of Pellionia, 4

Chromoplasts, in Daucus, 3

obscure rôle of, 3

C'losing layers, of lenticels, $10 \mathrm{~s}$

Coenocytes, relation to "Cell Theory," 1

Collateral vascular bunctle, in ror'n stem, 118

Collenchyma, air spaces in, $6 t$

functions of, $6: 2,64$

material for study of, 6t-65

occurrence of , 62

ontogeny of, $63-64$

regressive differentiation ot, 62

shape of cells in, 62

structure and composition of walls of. $62-63$

types of wall-thickening of, $(i 2-$ 63

use of term, $60^{\circ}$

Colleters, structure and oenurener of, $5 \div-53$

(ompanion colls, in phlorm of Cuturbitu, 9!

origin and strueture of, 93

Complementary tisssue, of lentirels, 108

Composite cylinder, formation of by selereides, $(98-69,120$

compound midelle liumella, study of, 11

Iste of termi, 10

siceveplate, use of term, 96

Cork (see also phellem) 
Cork, origin and strueture of, 107 (almbium (ser aloo phellogen) origin and fimetions of, 107-108

Corn, guard colls of leaf, 49 stuely of lat ot', 127-128 study of stem of, 118

Corjus, method of growth, 23 rôn in tissue differentiation, 23

Cortex, of roots, 131 of stems, 10)- 103 origin of, '23

Cotton, "fibers" of, 73

Crasislac, definition of, 13, 89

Crystals, in photosynthetie paren(hyma of Begonia, 59

nature of 5

role of molens in formation of, 5

types of', $5-6$

Crystal saes, arrangement of, 5,113

Cucmbita, sieve-tube elements of, 98-99

ressel derelopment in, 84

ressel elements of, 84,90

Cuticle, of epidermal cells, 46-4t

('utin, in walls of epidermal cells, 47

Cycres revolutu, diameter of shout apex, 22)

shoot apex, 20

(yotolith, devolopment in Fiens, 5()$-51$

use of term, 51

Cytoplasm, in hais cells, 2

Cytoplasmie strands, in hair cells, 2

streaming, in hair cells, 2-3

in leat rells of Elodea, 3

\section{D.tTTR.L, angular eollenchrona of, $64-65$}

Dancus, chomoplasts of, 3

vessel development in, 84

Definitive-callus, on sieve-plates. 97
Delignifieation, of walls of sclereidles, 69

Dermatogen (sec also protoderm, tunica)

in shoot apex, 24

origin of epirlermis from, 46

Dictyostele, general structure of, 104

Dilatation, of phloem rays, 114

Dionn edule, shoot apex, 20

Diospyros, entosperm of, 8

Druses, form and structure of , 5

Duckweed, raphicles in, 5

Dutehman's Pipe, study of stem of, $119-120$

ELAEAGNTS, seales of, 54

Elodea, chloroplasts in leaf of, 3 structure of shoot apex, 2t

Emergences, origin and morphology of, 51-5:

Endarch xylem, in siphonostele of stems, 103

Endodemis, functions of, 13t-135 morphology of, 104

of roots, 131

study of in Ramumenlus, 134-135

Endosperm, plasmorlesmata in, 8

Ephedru, vessel elements of, 8.2

Epidermal cells, form and structure of, $46-47$

pits in walls of, 47

wall-structure of, 47

Epidermal system, as defined by Sachs, 34

origin of, 24

Epidermis, a miseriate layer, 46

cell types in, 46

functions of, 45

Haberlandt's definition of, 45 material for study of, 48-49

multiple type of, 49-51

of Allium, 48-49

of geranium leaf, 49

of Gexman-Ivy leaf, 49 
Epidermis, of Iris leaf, 49 of onion bulb-scale, 48-49 of Pelurgonimm, 49

of petals, 46

of roots, 131

of Senicio, 49

of stems, 102

of Syrinya, 124-125

origin from puotoderm, 45-4t;

use of term, 45

Firgastic substances, general nature of, 4

Exarch xylem, in protostele of stems, 103

in stele of roots, 132

FASCICLLAR eambium, use of term, 106 svitem, as defined by Sachs, 34

Fibers, classification of, 74

form and length of, $7+-75$

functions of, 73

initials of, 76

material for study of, $77-78$

mielochemical tests for walls of, $77-78$

multinucleate protoplasts of, $76-7 T$

non-sclerotic types of, 75

occhuted lumen of, 75

of flax, 73

of hemp, 73

of textilo plants, 73

ontogeny of, $76-77$

positions in plant, it

selerenchymatoms types of, 7576

sliding-growth of, 76

structure and (omposition of walls, 75

use of term, 73

vestigial pits in, 1t-15, 75

Fiber-tracheids, development of septa in, 75

of P'imms, 88
Ficus, rystolith of, 51

multiple epidermis of, .50-51

Flax, fibers of, $73-74,75-76$

Flower, anatomical interpretation of, $101,10^{\circ} 2$

Free-hand sections, preparation of, $139-140$

Fundamental tissue system, as clefined hy Sachs, 34

Fusiform initials, 27,106

GERANIUM, cell walls in pith and cortex, 11

druses in, 5

multicellular umbranched hairs of, 53

study of epidermis of, 49

study of stem of, 10S-111

Ginkgo, shoot apex, 20

study of leaf of, $12 \mathrm{~s}$

Grape-vine, septate fibers of, is

Ground meristem, origin of collenchyma from, 63

Growing point (see also shoot apex), critique of term, "21

Guard cells, strueture of, $4 \bar{t}$

HAIRS (see also Trichomes), staminal hairs of Tructescomtia, ?

types and structme of, 5)

Half-bordered pit-pairs, structure of 14

study of, 14

Ilanstrin, histogen thoory of, 23, $25-26$

Hemp, fibers of, $73-74,75$

Hilmu, in stareh-grains, 4

Hippmris, structure of shoot apex, 24

Histogen theory, as applied to roots, 26

contrasted with tumica-rolpus throry, 23-24

Horse-cluestunt, rolleters on birl seales of, $5 t$ 
Hypericum, septate fiber-tracheids of, 77

Hypocotyl, study of primary xylem of, 87,88

ICE-PLANT, water vesicles of, 54

Idioblasts, illustration of, 36

in parenchyma tissues, 38

Inclusions (see Ergastic substances), 4

Intercalary growth, of leaf, 123 meristems, 18

Intercellular layer, structure and origin of, 9

spaces, in collenchyma of relery, 64

in mesophyll of Syringa, 125

in photosynthetic parenchyma of Begoniu, 60

Interfascicular cambium, origin of, 105

use of term, 106

Intussusception, method of wallthickening, ?

Iodine, test for stareh in Pellionia, 4

Iris, study of epidermis of, 49

Isotropic, use of term, 9

JCLANS, astrosclereides of, $70-71$

LATERAL meristems (see also vascular and cork cambium), 18

roots, origin and development of, 132-133

study of origin of, 136

Leaf, apical growth in, 123

evolution of, 123

from anatomical stanrpoint, 123

intercalary growth in, 123

origin of in grasses, 24

study of in Gintigo, 128
Leaf, study of in l'inus, 128 study of in Syringa, 124-1:27

study of in Zea, 12\%-128

Leaf anatomy, material for study of, 124-128

gaps, nature of, 102

traces, origin and development of, $105-106$

relation to leaf gaps, 102

use of term, 10)

Leaves, variations and types of, 123

Lemna, raphirles in, 5

Lenticels, function of, 108, 112 structure and development of, 108

Leucoplasts, function of, 4

Libriform fibers, of oak, 78

Lignin, in secondary wall, 10, 7576

Lilac, guard cells of leaf, 49

study of leaf of, 124-127

Linden, bast fibers of $77-78,113$

study of stem of, 111-117

Linum, multinucleate fibers of, 76 77

Liriodendron, study of ressel-elements of, 8!

Lithocrst, use of term, 51

Lumen, occlusion of, 9

occlusion in fibers, 75

in libriform fibers, 78

in macrosclereirles, 71

MACERATED tissue, of bean cotyledou, 59

of bean hypocotyl, 88

of Betula, 8!)

of Cucurbita, 90

of fruit of Curyu and Juglans, 70-71

of Liriodendron, 89

of Pinus, 13, 88-89

of Platanus, 15

of Quercus, 78, 89

of rhizome of Pteridium, 88 
Macerated tissue, of Tecoma, 12 of Tilia, 15, Ti

of Trifolium, 88

of ritis, 78

preparation of, 140-141

Macrosclereides, in testa of bean, 71

structure and oceurrence of, 68

Malpighian eells, in seed coat of legumes, 68

Medullary lays, in stem of Aristolochic, 119-120

in stem of Pelargonium. 10?

in stem of Tiliu, 116

origin of, 105

Meristem ring, use of term. 105

Meristematir tissue, classical con(eept of, 19, 28

difficulty of defining, 20 ()-21

restricted eoncept of, 19-20

vacuome in cells of, 20,25

Mrristems, and open system of growth, 18-19

apical, $21-27$

definition of, 18

interealary, 18

lateral, $27-28$

of determinate organs, 19

trpes according to position, 18

Mesembryanthemum, water resiales of , 53, 54

Mesophyll, of leaf of Pimm. 128 of leaif of $\% e r .127$

strueture in sigringu, 125-126

II stome sheath, in leat of $Z$ rene. $1: 27$

Motaphloesul, 86

Iretixylem, 85, S6i, 13:2

Monocotyledons, study of stem of. 118

Mulloin, demelend hairs of, 5.3

Multiple rpislermis, contlateded

will hyporlemis. 50

finction of, 50

material for study of, 50)-51
Multiple epidermis, occurrence of in angiosperms, 49-50

of Ficus elestica, 50-j1

ontogeny of, 50

use of term, 50

NACRE, use of term, !T

Nentral red, for staining valeuome, 142

use for cambium, 28

use for collenthyma, 64

use for epidermis, 4!

use for parenchyma, 5!)

Nicotiunu, ressel derelopment in, 84

Nodal anatomy, trpes of, 102

Nucleolus in hair cells, "2

Nuclens, disintegration in sievetube elements, 95

in hair cells, 2

OAK, libriform fibers ot, is

tracheids of, 89

ressel-efements of, 8!)-90)

Onion, study of epridermis oft. 4 s49

Ontogeny, of collendhy'nil tissure. 63-64

of companion cell, 93

of epidermis, 45-46

of fibers, $76-77$

of fibrons thickonines in trarheare, S1-86;

of leaf, 124

of leat traters, 105-1010

of lenticers, 108

of multiple epidermis, 4!-50)

of perforations in ressels, S3-84

of periderm, 107-108

of pits, 12!

of phimaly viaculale tissues in root, 132)

nl' scales in Shepherdiu, 5t

of sclereidles, (58-6is)

of sieve-plates, 97 
Ontogeny, of sieve-tube elements, 94- 97

of stele, 104-106, 131-1:32

of stoma, 48

of tracheary elements, 83-86

of vessel elements, 83-84

Organismal theory, 1

Osteosclereides, structure and oecurrence of', 68

PALISADE parenchyma, in leaf of syringu, 125

Paper, cellular composition of', 90 P'arenchyma, "ritique of concept of., 57

form of rells of, $57-58$

functions of, 58

material for study of, 59-60

photosynthetic, 59-60

jotoplasts of, 58-59

regressive differentiation of, 5859

storage, 59

structure and chemistry of walls of, 58

Jear, stone-cells of, 70

Pelaryonimm, cell walls in pith and coltex, 11

druses in, 5

multicellular umbranehed hairs of, 53

study of epidermis of, 49

study of stem of, 108-111

P'ellioniu, starch-containing ehlor(1) lasts of, 4

l'eperomia, multiple epirlermis of, 50

l'erforation-plate, in vessel alements of Pteridium, 88

types and evolution of, 83

Perforations, distinctive of ressel elements, 81

evolution of, $82-83$

outogeny of, $83-84$

types of, 83
Pericycle, critique of, 74

functions of in root, 132-134

Pericyclic tibers, in stem of Curnrbitu, 98

in stem of P'eleryonium, 109

Periderm, function of, $10 \bar{T}$

origin of in roots, 134

structure and development of, $107-108$

Persimmon, endosperm of, 8

Petmiu, sturly of stem hairs of. $2-3$

Phellem (see also Cork), origin and structure of, 107

Pletloderm, origin and structure of, 107

Phellngen (see also Cork cambium), origin and functions of, $107-108$

origin of in roots, 134

Phloem, complex structure of, 93

fiber's in, $74,76,94,11: 3$

functions of, 94

of Cucurbitu, 98-99

parenchyma, of Cuembita, 99

rays, in stem of Tiliu, 114

origin of, 27

structure of, 94

Phloroglucin and hydrocbloric acid, use as stain, 141

Phloroglueinol, use for bast fibers, 77

use for selereides, $70-71$

use for trarheary elements, 87

Picea, structure of shoot apex, 25

Pine, resin canals of, 117

secondary xylem of, 117

Pims, bordered pit-pairs in, 13 , 88-89

resin canals of, 117

study of cambinm of, 29

study of leaf of, 128

study of phloem of, 99

study of tracheids of, 88-89

pit aperture, nse of term, 11 
Pit eavity, use of term, 11 membrane, general structure of', 11

Pith, origin of, 23 phylogeny of, 103

Pit-pairs, between tracheae and living cells, 14

hortered, 13, 88-89 general strueture, 11

half-bordered, 14

simple, 12

types of, 12-15

use of term, 11

vestigial, $14-15,75,77$

Pits, function of, 12

in epidermal eells, 47

ontogeny of, 12

ramiform type in selereides, 68 , 70

use in eomparative study, 11

use of term, 11

Pitted elements, of metaxylem, 85

Plasmorlesmata, functions of, 8 in pit membranes, 12

in sicve-plates, 96

in tobaceo, 8

in walks of phloem eells, 98

nature of, 7

relation to "Cell Theory," 2, 8

secondary, $7-8$

sturly of in Diospyros, 8

Plastids, meaning of term, 3

types of, 3-4

Platanus, dendroid hairs of, 54

vestigial pit-pairs in, 15

Polarized light, appearance of walls under, 9-10

Pores, in sierr-plates, 96

Potassium iodide and sulphurie acid, nse as stain, 141

use for bast fibers, 77

Potato, storage parenchyma of, 59

Prepuned slides, importance of, 140
Primary phloem, cell types in, 94 differentiation of "in leaf traces, 105-106

radial arrangement in roots, 131-132

pit fields, definition of, 12

in cambial initials, 12

in primordial meristem, 12

ti-sues, in roots, 130-133

in stems, 102-10t

rascular system, ontogeny of, $104-106$

tissues, arrangement in roots, 131-132

arrangement in stems, 103 104

contrasted with secondary, 86-87

wall, of collenchyma cells, 63

of primary xylem trachean,

S1, 84,87

of sieve-tube elements, $97-98$

strueture and origin of, 9-10 xylem, differentiation of in leaf

traces, 105-106

endareh type of, 103

exareh in roots, 132

exareh type of, 103,132

material for stuly of, $8 \bar{i}-88$

radial arrangement in roots, 131-13:

radial aligmment of aels in stem, 86

secondary wall-thickenings of', $84-86$

vessels of in colery, 84

Primordial meristem, primary pit fields in, 12

pits, origin of siere-plates from, 97

Prismatic erystals, in Begoniu, 5!)

in Tilia, 5-6

oceurremese of, 5,5 !)

Procimbium (see also provascular meristem) 
Procambium, chandeteristics of , S6-8T

origin and tevelopment of, 23 , 104-106

origin of primary phloem from, $105-106,132$

origin of primary xylem from, $84-86,105-106,132$

produces pimary vasenlar syitrm, 27

Prodesmogen, use of term, 105

Progressive differentiation, from meristems, 20

of primary stem-tissues, $10^{2}$

Protorlerm (see also dermatogen), origin of epistermis from, $45-46$

origin of trichomes from, 51

Protophloen, in carrot, 132

Protoplasmic plant anatomy, 3!)

Protoplast, 1-6

Protostere. general structure of, 103

Protoxylem, tracheary alements of, $84-85$

use of term, 84

Provaseular meristem (nee also proeambinum), plodnces primary vascular system, 27

tissue, origin and development of, $23,104-106$

origin of primary phlocm froml, 105-106, 132

origin of primary xylem from, 8ł-86, 105-106, 132

Psilotales, sporophyte of, 101

Pteridium, primary xylem trarheae of, 88

Pyrus, brachysclereictes of, 70 stone-eells of, 70

QLERCTS, libriform fibers of, 78 tracheids of, 89
Quereus, vessel-eloments of s! s9-9)

RANTNCTLES, storage parenchyma of 5 !)

studly of root of, $13 t-136$

Raphides, form and structure of, 5 in Lemua, 5

in Tradeseantia, 5

Ray initials, 2т, 106

Rays, origin of from cambium, 27, 106

origin of in roots, 133-134

Regeneration, with reference to meristems, 21

Regressive differentiation, and concept of meristematic tissue, 21

and origin of phellogen, 107

and "permament" tissues, 32

of collenchyma, 62

of epidermis, 46

of parencllyma, .58-5!)

Reserve food, examples of, $t$

Resin canals, origin and structure in pine, 117

Reticulate elements, of metaxylem, 85

Rib meristem, concept of, "2t

in roots, 26

origin of cortex and pith from, 24

structure and growth of, 24

Rims of Samio (see Crassulac), 13,8 !)

Robinire, ontogeny of ressels in, 83-84

-tudy of eambium of, 28

study of phloem of, 9?

Root, branching of, 132-133

cortex of, 131

endodermis of, 131

epirlelmis of, 131

general featmes of, 130

material for study of, 134-136 
Root, ontogeny of primary raseular tissmes in, 132

primary tisture regions in, 131 133

sceondary wowth in, 133-134

study of in limumenlus, 134-136 study of in s'milar. 136

lioot apex, rontrasted with shoot apes, 131

histogens in, $25-26$

structure and growtl of, $25-27$, $130-131$

study of types of, 26

subtruninal meristem of, 25, 130-131

trpes of, .26, 130-131

zones in. 26

Root cap, function of, 25

methods of origin, 26

Root hairs, position of, 131

liublese plant, multiple epidermis of, $50-51$

SC'ALARJFOLid] rlements, of potoxylem, 84 perforation, 83, 88, 89

Sicales, ontogene of , 54

tryes and structure of, 5.

Sclerevides, dolignifieation of walls (of, (6!)

finction of , (i) - 70

material for study of, $70-71$

ontogeny of, 65-6!)

origin and use of term, 6 T

motoplasts of , 6?

types ofte tí-tis

wall strueture of, 6 T

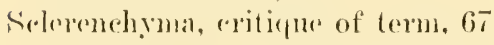
Serondary growth, in roots, 133134

in stems, $106-108$

study of in roots, 136

study of in stems, 110-111, 11:3$116,119-120$
Seeondary meristem, illustratrd by eambium, 27

phloem, eell types in, 94

seleresis, drecription of, 68-69)

in stem of a ristolochir. 120

raseular tissues, contrasted with primary. $86-8 T$

wall, discontimnous character of, 10-11

in siero-elements, 9s

of primary xylem tracheae. 84-86

origin and strueture of, 10-11

study of, 11

thres-layered type of 10

use of term, 10

xylem (sec tracheid and ressel)

(ell-arlangement in, 86

material for study of, $88-90$

Secretory cells, of resin eanals. 117

Selaginelle, vessels of. S:

senecio, stuly of epidemis of, $f$ ?

Septate fibers, structure of in Vitis, 78

Shepherelia, scales of', 54

Shoot, morphologe of, 101

Shoot apex, rentral racuolatert zone in, 20

diameter in angioperms, 2.)

diameter in grmmosperms, 2.2

form of (erls in, 2.)

in spereics with decoussate phyllotaxis, 201-20)

of amgiosperms, 20-25

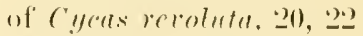

of Dionn edule. 20

of Cinliyo biloba. 20

of grmmopelms, $20,20,25$

of $/$ amill, 20

study of angiospermous types, $24-25$

study of grmnospermous types, 25 
Shoot apex, term replacing growing loint, 21

tminiea-corpus zone's of, 22-24

variation in form of, $21-2 \cdot 2$

Sieve-cell, of gymnospermous phloem, 93

Siere-firlel, origin and use of term, 96

Sieve-plate, morphology of, $96-97$ origin and structure of, $96-97$ position of, 96

Sieve-tube, solute-movement in, !) 4,95

use of term, ! 3

elements, contents of, 9.5-96

definitive cells of phloem, 93 disintegration of nuclei of , 95 in Cucurbitu, 98-99

literal walls of, 97-98

material for sturly of, 98-9?

obliteration of, 97

protoplasts of, 95-96

simple perforation, 83, $89-90$

pit-pairs, in xylem parencleymal of Tecoma, 12

sturly of , 12

Siphonostele. amphiphloic type of, 104

ectophloic type of, 104

general strueture of, 103

poblems of erolution of, 10:3

Slicling growth, of fibers, 7 (i

Slina-drops, in sieve-tube elements, 96

Slime-plugs, nature of, 95-96

Similure, sturly of root of, 136

solumm, rollenchyma of, 63

storage parenchyna of, 5!)

Special reagents, 141-142

Sphaerraphides (see Druses), 5

Spilal elements, of protoxylen, 81 Spongr latenchyma, functions of, $125-126$

in leaf ot syringn, 125
Spring trarcheids, of Pinus, 88-89

wood, of annual ring, 115

Squash (ree also ('urmbitu), study of strm hairs of, $2-3$

Starch, in chloroplasts of Pellionia, 4

in stolage tissues, $4,109,111$, 117,134

sheath, relation to stele, 104

Stelar theory, application of:, 103

Stele, bommlary of , 104

morphology of in loots, 132

ontogeny of in routs, 131-132

ontogeny of in stems, $104-106$

principal types of 103

structure and alevelopment of. 103-106, 131-132

structure of in roots, 131-13:

strueture of in stems, 103-104

types of in roots, 132

Stem, anatomy of in Cucurbita, 9s

cortex of, 102-103

(epidermis of, 102

material for study of, 108-120

morphology of, 101

nodal anatomy of, 101-10?

primary structure of, 102-104

secondan'y strueture of, 106-108

stele of, 103-106

structure of in grmmosperms, $11 \%-118$

study of in Aristolochiu, 11! 120

study of in eorn, 118

study of in monocotylerlons, 118

study of in Prlargonim, 108111

sturly of in pine, 117-11s

study of in Titir. 111-117

stury of vine-type of, 118-120

Stoma, action of guarel cells of, $47-48$

functions of, 47

ontogeny of, 48

use of term, 47 


\section{Stomate (see Stoma)}

Stone cells, strueture and oceurrence of, 68,70

Suberin, in walls of cork rells, 107 Subsidiary cells, of hairs, 53 of' stoma, ts

Suctan IV, use for epidermis, t9 usse of, 14:

Summer tracheids, of Pinus, 88 wood, of annual ring, 115

Sycamore, dendroid hairs of, 54 restigial pit-pair's in, 15

siyringa, guard cells of leaf, 4!) study of leaf of, 124-127

TECOUA rudicuns. simple pitpairs of, 12

Textile plants, fibers of, 73

Tilia, hast fiber's of, Ti-TS, 113

coll walls in pith and cortex, 11 study of stem of, 111-11t walls of bast fibers in, 11

Tissue, various definitions of, 3233

Tissues, complex, 38

difficulty of elassifying, 32, 3!)

Fames and MareDaniel's riasifieation, 37-38

Haherlandt's rlassification, 3537

Tundegaildllis's rassification, 36

permanent, 32

mintiry, 37, 86-87

Sach's classification, 33-35

seeoudary, 38, S6-8T

simple, 38

systrus: of rassification, 33-39)

Tobaceo, multimuleate fibers of, 76

Tomato, collenelyma of, 63

'Torms, in bordered pit-pairs, 13

Trachease, ontogeny of fibrous thickenings of, St-si

Trableary alements, ontogeny of, $83-86$
Tracheary elements, structure and morphology of, 80-53

study of in paper, 90

11:0 of term, 80

Tratcheid, borderesl pits of, 13, s:-2, 88-89

distribution of 81

fibrous thickenings in, 81 , St-86

general character's of', 80-81

imperforite character of, 81

in secondary xylem of oak, S?)90

in seeondary xylem of pinus, SS-S?

phylogenetic nature of', 81

study of, S8-8!

tripes of pitting in, 8:-

Tradescontia, raphisles in, 5

staminal hairs ot, :

strueture of sheot alpex, 24-25

Transfusion tisure, in leat of Pinus, 1요

Truns-location, in vascular sistem, So

merhanism of in phloem, 94-19) 'Triehomes, material for study of. 53-54

origin of, 51

types of, 5-5:3

use of ter'm, 51

Trichosunthes, ontogeny of tralchear in, 85

Trifolinu, primaly xylem of, sfi, S7, 88

vaseular bumelle of, $5 \overline{-}$

Triticum, origin of leaf in, 2.t

Trumpet-crecpere, simple pit-pairs of, 12

Tulip-tree, vessel alements of', s!)

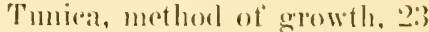

rîle in leaf and but intiation, $23-24$

rôle in tissure differentiation, 23's24

ralriation in number of layers of, $23-24$ 
TACUOLES, and wall-thiekenings of tracheae, 85

in cells of shoot apex, 2010

Vianome (see also ergastic substinces)

in cambial initials, 20, 227-28

in hair cells, ?

in meristems, 20, 2-7-28

Vasa mixta, use of term, 85

Valscular bundle (see also leaf traces), 86, si, 98, 110-111, 118-12011

of Aristolochin, 11!1-130

of eorm, 118

of Cueurbitu, 98

of Pelurgoninm, 110-111

of Trifolium, 86,87

Vasertar cambimm, coneept of, 106

fusiform initials of , 27,106

initials of $2-28,106$

study of living cells in Pimus, 28

study of living cells in hoblinie. 28

vacuolated enlls of, $2-28$

valseulan-ray initials of , 27,106 use of ter'm, $2 \bar{t}$

Viscular system, functions of, 80 general strueture and development, 80)

in bud-seales, 128

in leaf of Pinns, 128

in leaf of Syringu, 126-127

in leaf of $\% \rho u, 12 T-128$

Viaseular tissues, primary and seecudary, 86-87

Ierbusem, dendroid hair's of, 53

Vessel, use of term, 81

Tissel element, evolution and distribution of, 82-83

formation of perforations in, $83-84$

general character's of, 80-81

of Betule, 8!)

of Cuevrbita, 90

of Liriodendron, 89
Tessel clements, of oak, 89-90

of Pteridium, 88

ontogeny of, 83-84

pitting of , 82, $88,89-90$

structure of end walls of 84

study of, 89-90

Tescels, distribution in rascular plants, S:-83

in ferns, $8: 2,88$

Vestigial pit-pairs, in fiber's, 14 $15,75,77-78$

in wood fihers of Platumu, 15

morphology of, 14

morphology of in hast fibers, it study of, 14-15

Vitis, septate fiber's of, is

WATER, in walls of collenehyma cells, 63

vesicles, structure of in Mesembrycunthemum, 53, 54

Wood fibers, of oak, is

of Plutemes, 15

of ritis. 78

Wood parenehrma, of Tilia, 116

simple pit-pairs in, 12

Ford pulp, production of, 90

XYLEM, definitive eells of, 80 plates, use of term, 131

Xylem-ray parenchyma, simple pit-pairs in, 12

Xylem rays, of Tilie, 116

origin of, $2-7$

\% A MILA, shoot apex, 20

$Z c u$, guard rells of leaf, 49 stuty of leaf of, 127-12S

Zonal strueture, of angiospermous shoot apiere, 20-25

of gymnospermous shoot apices, 20,25

Zonation, of angiosperinoms shoot apices, 2:-2.5

of gymmospermous shoot apices, 20,25 




